\title{
De Limburgse arbeidsmarkt 1999-2004
}

Citation for published version (APA):

Diephuis, B. J., van Eijs, P. W. L. J., de Grip, A., Nekkers, G. J. A., Sanders, J. M. A. F., \& van Camp, H. (2000). De Limburgse arbeidsmarkt 1999-2004. Researchcentrum voor Onderwijs en Arbeidsmarkt, Faculteit der Economische Wetenschappen. ROA Reports No. 4 https://doi.org/10.26481/umarep.2000004

Document status and date:

Published: 01/01/2000

DOI:

10.26481/umarep.2000004

Document Version:

Publisher's PDF, also known as Version of record

\section{Please check the document version of this publication:}

- A submitted manuscript is the version of the article upon submission and before peer-review. There can be important differences between the submitted version and the official published version of record.

People interested in the research are advised to contact the author for the final version of the publication, or visit the DOI to the publisher's website.

- The final author version and the galley proof are versions of the publication after peer review.

- The final published version features the final layout of the paper including the volume, issue and page numbers.

Link to publication

\footnotetext{
General rights rights.

- You may freely distribute the URL identifying the publication in the public portal. please follow below link for the End User Agreement:

www.umlib.nl/taverne-license

Take down policy

If you believe that this document breaches copyright please contact us at:

repository@maastrichtuniversity.nl

providing details and we will investigate your claim.
}

Copyright and moral rights for the publications made accessible in the public portal are retained by the authors and/or other copyright owners and it is a condition of accessing publications that users recognise and abide by the legal requirements associated with these

- Users may download and print one copy of any publication from the public portal for the purpose of private study or research.

- You may not further distribute the material or use it for any profit-making activity or commercial gain

If the publication is distributed under the terms of Article $25 \mathrm{fa}$ of the Dutch Copyright Act, indicated by the "Taverne" license above, 


\title{
De Limburgse arbeidsmarkt 1999-2004
}

ROA-R-2000/4

\author{
B. Diephuis \\ P. van Eijs \\ A. de Grip \\ G. Nekkers \\ J. Sanders \\ H. van Camp (ETIL)
}

Researchcentrum voor Onderwijs en Arbeidsmarkt

Faculteit der Economische Wetenschappen en Bedrijfskunde

Universiteit Maastricht

Maastricht, maart 2000 
Niets uit deze uítgave mag worden verveelvoudigd en/of openbaar gemaakt door middel van druk, fotocopie, microfilm, of op welke wijze ook, zonder voorafgaande schriftelijke toestemming van de directeur van het Researchcentrum voor Onderwijs en Arbeidsmarkt. In geval van overname van het data-materiaal moet telkens als bron worden vermeld: "Researchcentrum voor Onderwijs en Arbeidsmarkt" of "ROA". Van publicaties waarin gebruik wordt gemaakt van gegevens uit dit rapport ontvangen wij gaarne een exemplaar.

Hoewel de grootst mogelijke zorg is besteed aan de inhoud van dit rapport, kan het ROA in generlei opzicht verantwoordelijkheid op zich nemen voor eventuele onvolledigheden of onjuistheden.

\section{Colofon}

Vormgeving omslag Lenting en Terlingen Grafisch Ontwerp Lay-out, dtp en druk Unigraphic, Universiteit Maastricht Oplage 800 exemplaren 


\section{Inhoudsopgave}

Voorwoord 1

Verschenen RAIL publicaties

Ten geleide $\quad \mathrm{V}$

1 De Limburgse arbeidsmarkt in vogelvlucht 1

1.1 Inleiding 1

1.2 De recente arbeidsmarktontwikkeling in Limburg: 1997-1999 2

1.3 De verwachte arbeidsmarktontwikkeling op korte en middellange termijn 5

$\begin{array}{lll}1.4 & \text { Ontwikkelingen naar bedrijfssector } & 7\end{array}$

$\begin{array}{ll}1.5 & \text { Ontwikkelingen naar beroepssector } \\ 1.6 & 10\end{array}$

$\begin{array}{ll}1.6 & \text { Ontwikkelingen naar opleidingssector } \\ 1.7 & 12\end{array}$

$\begin{array}{lll}1.7 & \text { De participatiegraad in Limburg } & 13\end{array}$

2 Actuele discrepanties op de Limburgse arbeidsmarkt $\quad 15$

$\begin{array}{ll}2.1 \text { Inleiding } & 15\end{array}$

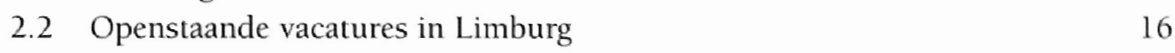

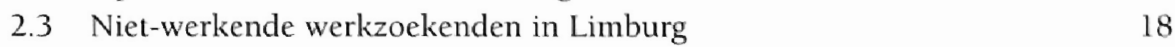

$\begin{array}{ll}2.4 & \text { Discrepanties op de Limburgse arbeidsmarkt }\end{array}$

2.5 De actuele arbeidsmarktpositie van schoolverlaters 26

3 De Limburgse arbeidsmarkt in $2000 \quad 35$

$\begin{array}{ll}3.1 & \text { Inleiding } \\ 3.2 & 35\end{array}$

3.2 Knelpunten op de Limburgse arbeidsmarkt in $2000 \quad 36$

3.3 Vraaggericht scholingsbeleid 41

$\begin{array}{lll}3.4 & \text { Aandachtspunten voor het scholingsbeleid } & 48\end{array}$

4 De Limburgse arbeidsmarkt in 2004

4.1 Inleiding 51

4.2 Arbeidsmarktperspectieven van schoolverlaters in 2004

4.3 De arbeidsmarkt voor hoger opgeleiden in $2004 \quad 56$

4.4 Kansen op de arbeidsmarkt: een typologie $\quad 57$

$\begin{array}{ll}4.5 & \text { Aandachtspunten voor het onderwijsbeleid }\end{array}$

5 Regionale en sectorale perspectieven $\quad 65$

$\begin{array}{lll}5.1 & \text { Inleiding } & 66\end{array}$

5.2 Een verbijzondering naar regio 66

5.3 Sectorspecifieke knelpunten: oorzaken en oplossingen 71 
6 Pendel en participatie: Oplossingen voor knelpunten?

$\begin{array}{lll}6.1 & \text { Inleiding } & 81\end{array}$

6.2 Pendel op de Limburgse arbeidsmarkt 82

6.3 Non-participatie in Limburg: Omvang en samenstelling 83

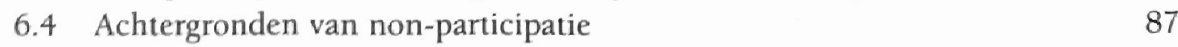

$\begin{array}{lr}\text { Verklarende woordenlijst } & 89\end{array}$

$\begin{array}{ll}\text { De nieuwe kwalificatiestructuur } & 95\end{array}$ 


\section{Voorwoord}

De dynamiek op de Limburgse arbeidsmarkt zet zich onverminderd in sterke mate voort. Het afgelopen jaar is de krapte op de markt van arbeidsvraag en arbeidsaanbod verder toegenomen. In steeds meer sectoren komt de personeelswerving onder zware druk te staan. Veel vacatures zijn niet of slechts met grote moeite te vervullen. Aan de aanbodkant daalt de werkloosheid. Nadat in eerste instantie vooral jongeren met een afgeronde opleiding profiteerden van de economische groei, vinden ook steeds meer werkzoekenden met een grotere afstand tot de arbeidsmarkt een arbeidsplaats.

De spanning tussen vraag en aanbod zal de komende jaren groot blijven. Enerzijds wordt dit veroorzaakt door een verdere groei van de werkgelegenheid, anderzijds zullen in de nabije toekomst veel werkenden als gevolg van het bereiken van de pensioengerechtigde leeftijd de arbeidsmarkt verlaten. Het aantal werklozen zal zowel in kwalitatieve als in kwantitatieve zin niet toereikend zijn om de vraag vanuit het bedrijfsleven en andere arbeidsorganisaties in te vullen. Ontginning en mobilisatie van nieuw aanbod zal noodzakelijk zijn om fricties betekenisvol te verminderen. Momenteel wordt er reeds in toenemende mate een beroep gedaan op aanbod uit het buitenland en op stille arbeidsreserve.

Om de arbeidsmarkt in Limburg op de voet te kunnen volgen is een aantal jaren geleden de arbeidsmarktmonitor RAIL (Regionale Arbeidsmarkt Informatie Limburg) in het leven geroepen. RAIL is een samenwerkingsverband tussen de Provincie Limburg, De Regionale Opleidingencentra, Arbeidsvoorziening Limburg, de Limburgse Werkgevers Vereniging, de Federatie Nederlandse Vakbeweging en Limburgse gemeenten.

Voor $\mathrm{u}$ ligt de derde publicatie van RAIL, die is samengesteld door het Researchcentrum voor Onderwijs en Arbeidsmarkt (ROA) in samenwerking met het Economisch Technologisch Instituut Limburg (ETIL). De rapportages in vier delen, geven een gedetailleerd beeld van actuele en toekomstige ontwikkelingen op de Limburgse arbeidsmarkt, inclusief een middellange termijnprognose tot en met 2004. Hierbij wordt expliciet aandacht geschonken aan ontwikkelingen per sector, beroepsgroep en opleidingstype. Naast een schets van de markt op Limburgse schaal wordt tevens aandacht geschonken aan kenmerken en ontwikkelingen op de verschillende deelmarkten. Specifiek wordt stilgestaan bij de belangrijkste trends in een aantal rayons.

Gesteld mag worden dat RAIL zich de afgelopen drie jaar heeft ontwikkeld tot een belangrijke leverancier van informatie over ontwikkelingen op de arbeidsmarkt. Steeds meer actoren maken gebruik van de bevindingen, conclusies en voorspellingen van RAIL in hun streven knelpunten op de markt van arbeidsvraag en arbeidsaanbod te verminderen. Verwacht mag worden dat voor bedrijven en branches, voor gemeenten in het kader van hun nieuwe taken als gevolg van de herstructurering sociale zekerheid, het gebruik van regionale beleidsinformatie sterk zal toenemen.

Het voor u liggende rapport maakt duidelijk dat de krapte is doorgedrongen in vrijwel alle sectoren. Vooral de dienstensector kan moeilijk aan personeel komen. Ook de komende jaren zal de groei van het aantal vrijkomende arbeidsplaatsen groter zijn dan de instroom van nieuwkomers. Dit betekent dat niet verwacht mag worden dat fricties zullen verdwijnen. 
Uiteraard worden er vele inspanningen gepleegd om de problematiek te verminderen. Evenals vorig jaar wil RAIL een aanzet geven voor mogelijke oplossingsrichtingen. In het rapport wordt aandacht geschonken aan bij- en omscholingsmogelijkheden voor werklozen en worden een aantal aandachtspunten voor onderwijsbeleid geformuleerd. Ook wordt gekeken naar mogelijkheden om personen in te passen die momenteel nog niet participeren op de arbeidsmarkt. Het aantal mensen dat niet participeert is immers hoog. Verder wordt bekeken in welke mate pendel vanuit Duitsland en Belgiē een bijdrage kan leveren aan een vermindering van huidige en toekomstige knelpunten.

RAIL heeft de afgelopen jaren bewezen voor een belangrijk deel in een informatiebehoefte te voorzien. Ik ben ervan overtuigd dat RAIL ook de komende jaren een solide basis zal vormen voor het vinden van de juiste oplossingen voor knelpunten op de Limburgse arbeidsmarkt.

Voorzitter stuurgroep RAIL

Drs. J.Th. Sørensen 


\section{Verschenen RAIL-publicaties:}

98.RAIL-01: De Limburgse arbeidsmarkt 1997-2002; hoofdrapport*

98.RAIL-02: De Limburgse arbeidsmarkt 1997-2002; statistische bijlage *

98.RAIL-03: Kwalitatieve informatie over de Limburgse arbeidsmarkt; werkdocumenten industrie, handel ${ }^{*}$

99.RAIL-04: De Limburgse arbeidsmarkt 1998-2002; hoofdrapport

99.RAIL-05: De Limburgse arbeidsmarkt 1998-2002; statistische bijlage

99.RAIL-06: De Limburgse arbeidsmarkt 1998-2002; sectorrapportage bouw - zakelijke dienstverlening - zorg

99.RAIL-07: De Limburgse arbeidsmarkt 1998-2002; beknopte rapportage

00.RAIL-08: De Limburgse arbeidsmarkt 1999-2004; hoofdrapport

00.RAIL-09: De Limburgse arbeidsmarkt 1999-2004; statistische bijlage

00.RAIL-10: De Limburgse arbeidsmarkt 1999-2004; sectorrapportage horeca, toerisme \& recreatie en overheid

00.RAIL-11: De Limburgse arbeidsmarkt 1999-2004; beknopte rapportage

* Publicatie niet meer in boekvorm verkrijgbaar.

\section{RAIL op internet}

Internet: www.railsite.nl 


\section{Ten geleide}

Van verschillende kanten is er een behoefte aan betrouwbare informatie over de actuele en toekomstige arbeidsmarktsituatie in Limburg. Deze informatiebehoefte vormde de aanleiding tot het project Regionale Arbeidsmarkt Informatie Limburg (RAIL), dat beoogt te komen tot een geïntegreerd informatiesysteem toegespitst op de provincie Limburg. In het RAILproject participeren Arbeidsvoorziening Limburg, de Provincie Limburg, Kennis Connect (voorheen RBO Zuid-Limburg), de Regionale Opleidingscentra (ROC's), de Federatie Nederlandse Vakbeweging (FNV) en de Limburgse Werkgevers Vereniging (LWV). Er wordt derhalve samengewerkt door een aantal partners die zowel gebruiker als leverancier van informatie zijn.

Het thans voor U liggende rapport De Limburgse arbeidsmarkt 1999-2004 vormt de derde versie van het overzichtsrapport dat het Researchcentrum voor Onderwijs en Arbeidsmarkt (ROA), in samenwerking met het Economisch Technologisch Instituut Limburg (ETIL), in het kader van RAIL heeft samengesteld. Dit rapport is primair gericht op het in kaart brengen van de actuele en toekomstige discrepanties naar bedrijfssector, beroep en opleiding op de Limburgse arbeidsmarkt. Tegelijkertijd met dit rapport verschijnt ook de bijbehorende Statistische Bijlage. Hierin wordt een systematisch kwantitatief overzicht gegeven van de actuele arbeidsmarktgegevens en de verwachte -ontwikkelingen die ten grondslag liggen aan dit hoofdrapport.

Teneinde de discrepanties zo goed mogelijk in kaart te brengen omvat het informatiesysteem niet alleen kwantitatieve informatie, maar ook kwalitatieve informatie. De kwalitatieve informatie is verzameld en gegenereerd door ETIL. Deze informatie bied de mogelijkheid om specifieke aspecten van de Limburgse arbeidsmarktproblematiek te belichten. De kwalitatieve informatie in deze rapportage is gericht op twee speerpuntsectoren: de sector horeca, toerisme en recreatie alsmede de sector overheid'. De inzichten en conclusies die voortkomen uit de kwalitatieve informatie zijn verwerkt in de door ETIL samengestelde RAIL-publicatie De Limburgse arbeidsmarkt 1999-2004; sectorrapportage horeca, tocrisme \& recreatie en overheid die gelijktijdig met dit hoofdrapport is verschenen.

Dit hoofdrapport is gebaseerd op zowel de kwantitatieve als de kwalitatieve informatie. Centraal hierbij staat het streven om zoveel mogelijk het complementaire karakter van de informatie te benutten. Hierbij biedt de kwantitatieve informatie een raamwerk dat met behulp van de kwalitatieve informatie nader is ingekleurd, verdiept en verbijzonderd, opda een systematisch en gedetailleerd beeld van de aansluitingsproblematiek in de regio verkre gen wordt. Door zowel de huidige situatie als de toekomstige ontwikkelingen op zowel kwantitatieve als kwalitatieve wijze in kaart te brengen, heeft RAIL een signaleringsfunctie voor diverse gebruiksdoelen. Hierbij kan gedacht worden aan het personeels- en rekruteringsbeleid van werkgevers, het initiëren en bijsturen van bij- en omscholingsprogramma's voor niet-werkende werkzoekenden, de arbeidsbemiddeling, het (provinciale) arbeidsmarktbeleid en het onderwijsbeleid.

I In eerdere rapportages is door het ETIL aandachı besteed aan de sectoren handel, industrie, bouw, zakelijke dienstverlening en zorg. 
In het voorliggende rapport wordt slechts in beperkte mate ingegaan op de gehanteerde onderzoeksmethoden, de gehanteerde classificaties, e.d. Wél zijn achterin dit rapport enkele centrale begrippen op een rij gezet en nader omschreven. Daarnaast wordt in het rapport, waar nodig, uitleg gegeven over de gebruiksmogelijkheden van de gepresenteerde informatie.

In dit rapport is op verschillende manieren vorm gegeven aan een verdere verbreding en verdieping van het RAIL-informatiesysteem in vergelijking met de afgelopen jaren. Ten eerste is verder gezocht naar de optimale classificaties, gegeven de kwaliteit van de data en de daadwerkelijke verschillen tussen verschillende arbeidsmarktsegmenten (i.c. bedrijfssectoren, beroepen, opleidingen en subregio's). Op de tweede plaats is de naamgeving van de verschillende opleidingstypen in dit rapport in overeenstemming gebracht met de nieuwe kwalificatiestructuur zoals die is vastgelegd in de WEB (Wet Educatie en Beroepsonderwijs).

Het rapport bestaat uit zes hoofdstukken. De eerste vier hoofdstukken geven een overzicht van de huidige en toekomstige ontwikkelingen op de Limburgse arbeidsmarkt. In hoofdstuk 1 wordt een globaal overzicht gegeven van de belangrijkste arbeidsmarktontwikkelingen verbijzonderd naar bedrijfs-, beroeps- en opleidingssector. In hoofdstuk 2 wordt getracht een antwoord te geven op de vraag in hoeverre er op dit moment voldoende geschikte niet-werkende werkzoekenden beschikbaar zijn om de openstaande vacatures te vervullen en in hoeverre er voldoende openstaande vacatures zijn om de niet-werkende werkzoekenden aan een baan te helpen. Daarbij gaat het zowel om de kwantitatieve als de kwalitatieve discrepanties. Hoofdstuk 3 en 4 gaan nader in op de te verwachten ontwikkelingen op de korte en middellange termijn aan zowel de vraag- als de aanbodzijde van de Limburgse arbeidsmarkt, hetgeen resulteert in een overzicht van de te verwachten discrepanties tussen vraag en aanbod naar opleiding en beroep in 2000 respectievelijk 2004. Verder wordt er aandacht besteed aan de actuele arbeidsmarktpositie van schoolverlaters van het $\mathrm{MBO}$ en aan de vraag in hoeverre het mogelijk is om via scholing van niet-werkende werkzoekenden de discrepanties op de Limburgse arbeidsmarkt te verminderen.

De laatste twee hoofdstukken verdiepen vanuit een aantal perspectieven het geschetste beeld dat uit de eerste vier hoofdstukken naar voren komt. Hoofdstuk 5 biedt een regionale en sectorale verbijzondering van onder meer de huidige en toekomstige knelpunten in de personeelsvoorziening. Wat betreft de sectorale verbijzondering wordt daarbij ingegaan op de achtergronden van de tekorten aan geschikt personeel in de twee sectoren die dit jaar in het RAIL-rapport nader onder de loep zijn genomen. Bovendien wordt een aantal structuurkenmerken van de Limburgse rayons gepresenteerd. In hoofdstuk 6 worden de gesignaleerde actuele en toekomstige discrepanties op twee manieren nader beschouwd. Er wordt onderzocht in hoeverre middels het bevorderen van de internationale pendel en/of van de arbeidsmarktparticipatie in Limburg de knelpunten in de personeelsvoorziening kunnen worden verlicht.

De projectleiding van RAIL is bij het ROA in handen van P. van Eijs en A. de Grip. Aan de huidige versie van het hoofdrapport en de bijbehorende Statistische Bijlage is bij het ROA meegewerkt door B. Diephuis, N. van Hal, G. Nekkers en J. Sanders. Bij ETIL is de projectleiding van RAlL in handen van $\mathrm{H}$. van Camp. 
Onze dank gaat uit naar de leden van de RAlL-stuurgroep en -projectteam. De volgende personen hebben hierin zitting: G. Ahn (Arbeidsvoorziening Limburg, secretaris), M. te Baerts (Leeuwenborgh Opleidingen), T. Beenackers-Oomen (Kennis Connect), H. Droppert (Arbeidsvoorziening Limburg), H. Duijvestein (Arbeidsvoorziening Limburg, projectleider), P. Goobbels (FNV Limburg), H. Houbraken (Kennis Connect), W. Huurdeman (Gilde Opleidingen), H. de Jong (Provincie Limburg), W. Kohl (Arcus College), P. Peters (Arcus College), L. Simons-Heldens (Gilde Opleidingen), M. van Smoorenburg (Arbeidsvoorziening Limburg, secretaris), J. Soogelée (Leeuwenborgh Opleidingen), J. Sørensen (DSM, voorzitter stuurgroep), G. Wolfs (Provincie Limburg) en L. Zeegers (LWV). 


\section{De Limburgse arbeidsmarkt in vogelvlucht}

Dit hoofdstuk geeft een overzicht van de belangrijkste recente en toekomstige ontwikkelingen op de Limburgse arbeidsmarkt. De laatste jaren is het aantal openstaande vacatures sterk toegenomen. Van 1997 op 1998 is het aantal openstaande vacatures zelfs meer dan verdubbeld. In 1999 is daarentegen het aantal openstaande vacatures weer wat gedaald. Met name in de sectoren handel, transport en communicatie en kwartaire diensten is de arbeidsmarktkrapte in 1999 echter sterk toegenomen. Meer dan 30\% van de vacatures staat langdurig open. De toegenomen krapte op de arbeidsmarkt komt ook tot uiting in de sterke daling van het aantal niet-werkende werkzoekenden. Ook het percentage langdurig werkzoekenden is aanzienlijk teruggelopen. Het percentage niet-werkende werkzoekenden dat door Arbeidsvoorziening beschouwd wordt als direct bemiddelbaar ligt de laatste 2 jaar iets onder de $20 \%$, hetgeen beduidend lager is dan in 1997. Het aandeel van de niet-werkende werkzoekenden dat is ingedeeld in fase 2 en 3 is daarentegen de laatste jaren sterk toegenomen. Bovendien is de kwaliteit van het aanbod binnen de fasen 2 en 3 afgenomen.

De komende jaren zal de spanning op de Limburgse arbeidsmarkt nog groter worden. Gezien de huidige krappe arbeidsmarkt en het gegeven dat de verwachte baanopeningen de verwachte instroom van schoolverlaters overtreffen, zullen de knelpunten op de arbeidsmarkt zich de komende jaren verscherpen.

De economische groei die Limburg de laatste jaren doormaakt, zal zich naar verwachting op de korte en middellange termijn voortzetten. De positieve ontwikkeling van de werkgelegenheid is echter naar verwachting beperkt en zal zich niet in alle bedrijfssectoren voortzetten. Zo wordt in 2000 een daling verwacht van de werkgelegenheid in de sectoren chemie, energie, bouw en onroerend goed, overheid en onderwijs, metaal en elektrotechniek, bank- en verzekeringswezen en overige industrie. Op de middellange termijn wordt voor alle industriesectoren een krimpende werkgelegenheid verwacht. De toekomstige knelpunten zijn met name geconcentreerd in de handel en de kwartaire diensten. De groei die voor de verschillende sectoren verwacht wordt, vertaalt zich ook naar de diverse beroepen en opleidingen. Voor het jaar 2000 wordt de sterkste werkgelegenheidsgroei verwacht voor de informaticaberoepen. Verder is er groei in de verzorgende en dienstverlenende, de economisch-administratieve en de transportberoepen. Op middellange termijn blijft dit beeld in grote lijnen bestaan. Tussen de verschillende opleidingssectoren loopt de vraagontwikkeling sterk uiteen. Voor de meeste opleidingssectoren is er sprake van goede arbeidsmarktperspectieven. Duidelijk minder positief zijn de vooruitzichten voor mensen met alleen Basisonderwijs en in de opleidingssector VMBO Economie.

\subsection{Inleiding}

In dit hoofdstuk zal een globale schets worden gegeven van de belangrijkste ontwikkelingen op de Limburgse arbeidsmarkt. Eerst wordt een aantal indicatoren gepresenteerd die de recente ontwikkeling van de arbeidsmarkt in Limburg illustreren. Hierbij zal ook worden ingegaan op achterliggende vraag- en aanbodfactoren. Vervolgens wordt aandacht besteed aan de verwachte ontwikkeling tot 2004. Deze wordt tevens verbijzonderd naar bedrijfs-, beroeps- en opleidingssector. Verwacht wordt dat werkgevers in Limburg zowel op de korte 
alsook op de wat langere termijn op een groot aantal arbeidsmarktsegmenten problemen zullen bijven ondervinden bij het aantrekken van personeel.

\subsection{De recente arbeidsmarktontwikkeling in Limburg: 1997-1999}

\section{Arbeidsvraag}

Tabel 1.1 illustreert de ontwikkeling aan de vraagzijde van de Limburgse arbeidsmarkt tussen 1997 en 1999. Van 1997 op 1998 blijkt het aantal openstaande vacatures meer dan verdubbeld te $\mathrm{zijn}^{2}$. In 1999 is daarentegen het aantal openstaande vacatures gedaald. Dit is in overeenstemming met eerdere prognoses van de vacaturemarkt in Limburg door het Nederlands Economisch Instituut ${ }^{3}$. Er dient bij een vergelijking van vacaturecijfers tussen de verschillende jaren overigens wel bedacht te worden dat er sprake is van verschillende meetmomenten, hetgeen doorgaans tot enige vertekening leidt. Wanneer niet expliciet rekening wordt gehouden met seizoenseffecten, kan het voorkomen dat het aantal openstaande vacatures in een bepaald jaar enigszins over- of onderschat wordt.

Naast het aantal openstaande vacatures wordt in de tabel een tweetal indicatoren gepresenteerd die aangeven in welke mate werkgevers in de jaren 1997-1999 rekruteringsproblemen hebben ondervonden op de Limburgse arbeidsmarkt:

- de vacaturegraad geeft het aantal openstaande vacatures als promillage van de werkgelegenheid weer en laat zien hoe groot de inspanning is die door bedrijven en instellingen verricht moet worden om in de behoefte aan nieuw personeel te voorzien;

- het percentage langdurig openstaande vacatures geeft aan in hoeverre bedrijven moeite hebben om hun vacatures op korte termijn te vervullen.

Voor de vacaturegraad is per definitie dezelfde trend waarneembaar als voor het aantal openstaande vacatures. Dit geldt eveneens voor het percentage langdurig openstaande vacatures, al speelt hier vanzelfsprekend ook het arbeidsaanbod een rol: Als het aanbod gering is, zullen er zelfs bij een beperkt aantal openstaande vacatures rekruteringsproblemen optreden. Uit tabel 1.1 blijkt dat het percentage langdurig openstaande vacatures de afgelopen jaren boven de $30 \%$ is komen te liggen.

Tabel 1.1

Ontwikkelingen aan de vraagzijde van de Limburgse arbeidsmarkt, 1997-1999

\begin{tabular}{lrrr} 
& februari 1997 & juli 1998 & april 1999 \\
\hline Aantal openstaande vacatures & 8.100 & 16.200 & 14.300 \\
Vacaturegraad (\%o) & 24 & 36 & 31 \\
Langdurig openstaande vacatures (\%) & 27 & 32 & 31 \\
\hline
\end{tabular}

Bron: Arbeidsvoorziening/CBS/ROA

2 Het totale aantal openstaande vacatures in tabel 1.1 is berekend door het aantal openstaande vacatures dat is gemeld bij Arbeidsvoorziening Limburg te delen door het marktbereik voor de vacaturemarkı zoals dat naar voren komt uit de Vacature-enquête van het Centraal Bureau voor de Statistiek. Hierbij dient wel opgemerkt te worden dat de vacaturemarkt voor flexibel werk buiten beschouwing is gelaten.

3 Zie Ecn Korte Schets van de Limburgse Arbeidsmarkt, Arbeidsvoorziening Limburg, Sittard, juni 1999. 


\section{Arbeidsaanbod}

Tabel 1.2 laat zien dat het aantal niet-werkende werkzoekenden de laatste jaren aanzienlijk is gedaald ${ }^{4}$. De daling tussen 1997 en 1998 bedroeg maar liefst 27\%, terwijl in 1999 het aantal niet-werkende werkzoekenden nog eens met $13 \%$ is gedaald. Ook het percentage langdurig werkzoekenden blijkt behoorlijk te zijn teruggelopen. Momenteel is nog $56 \%$ van het totaal aantal niet-werkende werkzoekenden langer dan een jaar werkloos. Het percentage niet-werkende werkzoekenden dat door Arbeidsvoorziening beschouwd wordt als direct bemiddelbaar (degenen die zijn ingedeeld in fase 1) ligt de laatste 2 jaar iets onder de $20 \%$, hetgeen beduidend lager is dan in 1997. Dit weerspiegelt het gegeven dat in eerste instantie vooral werkzoekenden met een kleine afstand tot de arbeidsmarkt profiteren van de verbeterde economische situatie. Dit is vooral ten koste gegaan van niet-werkende werkzoekenden in fase 2 en 3 . Het aandeel van deze groep in het totale bestand is de laatste jaren behoorlijk toegenomen. Bovendien is de kwaliteit van het aanbod binnen de fasen 2 en 3 afgenomen. Dit zou kunnen samenhangen met de wijze waarop werkzoekenden in een bepaalde fase worden ingedeeld. Zo wordt wel gesteld dat in een situatie van arbeidsmarktkrapte bij consulenten de neiging bestaat werkzoekenden in een fase in te delen die grotere baankansen biedt ${ }^{s}$.

Tabel 1.2

Ontwikkelingen aan de aanbodzijde van de Limburgse arbeidsmarkt, 1997-1999

\begin{tabular}{|c|c|c|c|c|c|c|}
\hline & \multicolumn{2}{|c|}{ februari 1997} & \multicolumn{2}{|c|}{ juli 1998} & \multicolumn{2}{|c|}{ april 1999} \\
\hline & aantal & $\%$ & aantal & $\%$ & aantal & $\%$ \\
\hline Aántal niet-werkende werkzoekenden & 59.400 & & 43.000 & & 37.300 & \\
\hline \multicolumn{7}{|l|}{ waarvan } \\
\hline - langdurig werkzoekend & 46.300 & 78 & 26.700 & 62 & 20.900 & 56 \\
\hline - fase 1: direct bemiddelbaar & 20.800 & 35 & 7.300 & 17 & 7.100 & 19 \\
\hline - fase 2 en 3: afstand tot de arbeidsmarkt & 19.600 & 33 & 20.200 & 47 & 17.500 & 47 \\
\hline - fase 4: slecht bemiddelbaar & 19.000 & 32 & 15.500 & 36 & 12.700 & 34 \\
\hline
\end{tabular}

Bron: Arbeidsvoorziening/ ROA

\section{Discrepanties}

Wanneer vraag en aanbod met elkaar worden geconfronteerd, ontstaat een indicator van de mate waarin er sprake is van arbeidsmarktkrapte. Deze indicator geeft aan in hoeverre het aanbod van niet-werkende werkzoekenden in fase 1 toereikend is om de openstaande vacatures op te kunnen vullen. Uit tabel 1.3 blijkt dat de krapte op de Limburgse arbeidsmarkt tussen 1997 en 1998 aanzienlijk is gestegen. Waren er in 1997 nog slechts 39 openstaande

4 Bij het bepalen van het aantal niet-werkende werkzoekenden is de categorie werkzoekenden die geen beroep doen op de dienstverlening buiten beschouwing gelaten; het betreft hier ongeveer 5.500 personen.

5 Zic Aanbodanalysc: Belemmeringen en Kansen, Arbeidsvoorziening Limburg, Siltard, okiober 1999. 
vacatures per 100 direct inzetbare niet-werkende werkzoekenden, in 1998 stonden er tegenover iedere 100 direct inzetbare niet-werkende werkzoekenden maar liefst 222 openstaande vacatures. Voor deze verkrapping zijn twee oorzaken aan te wijzen. In de eerste plaats is het aantal openstaande vacatures in deze periode aanzienlijk toegenomen. Dit blijkt ook uit de toegenomen vacaturegraad in tabel 1.1. In de tweede plaats is het aantal niet-werkende werkzoekenden, en dan met name het direct inzetbare deel daarvan, sterk afgenomen. De grotere krapte manifesteert zich ook in het toegenomen aantal langdurig openstaande vacatures.

Tussen juli 1998 en april 1999 lijkt de arbeidsmarktkrapte in Limburg daarentegen enigszins te zijn afgenomen. Dit is met name het gevolg van het lagere aantal openstaande vacatures. Dit betekent echter niet noodzakelijkerwijs dat de arbeidsmarktkrapte op alle marktsegmenten is afgenomen. Zo is in de sector handel bijvoorbeeld de krapte aanzienlijk toegenomen (van 2,13 naar 2,84; zie figuur 1.1). In tabel 1.3 is tevens aangegeven voor hoeveel bedrijfssectoren er in de verschillende jaren sprake was van een krappe arbeidsmarkt. Daaruit blijkt dat het aantal sectoren dat in 1999 met krapte werd geconfronteerd groter was dan in 1998.

Tabel 1.3

Krapte op de Limburgse arbeidsmarkt, 1997-1999

\begin{tabular}{lccc} 
& februari 1997 & juli 1998 & april 1999 \\
\cline { 1 - 3 } Arbeidsmarktkrapte $^{*}$ & 0,39 & 2,22 & 1,99 \\
Aantal bedrijfssectoren met krapte & 0 & 11 & 12 \\
\hline
\end{tabular}

* direct inzetbare werkzoekenden ten opzichte van aantal openstaande vacatures

Bron: Arbeidsvoorziening/CBS/ROA

In figuur 1.1 wordt een overzicht gegeven van de ontwikkeling van de krapte op de Limburgse arbeidsmarkt verbijzonderd naar bedrijfssector. Tussen 1997 en 1998 blijkt in alle sectoren de krapte te zijn toegenomen, waarbij de sterkste stijging betrekking had op de industriële sectoren, met name voeding en chemie. Relatief gering was de stijging in de sectoren landbouw en visserij en energie. In 1999 is er daarentegen ten opzichte van het jaar ervoor voor een aantal sectoren sprake van een daling van de arbeidsmarktkrapte. De sterkste afname betrefi de sectoren voeding en chemie die daarvoor juist zo explosief waren geste$\mathrm{gen}^{\circ}$. Deels is dit te wijten aan het teruglopen van het aantal openstaande vacatures. Zo is in de chemie dit aantal gedaald van 200 in 1998 naar 150 in 1999, terwijl in de voeding het aantal op 200 is gestabiliseerd. Een verklaring hiervoor zou een afzwakking van de investeringsneiging kunnen zijn in reactie op de grote krapte in deze beide sectoren in 1998. Daarnaast wordt de chemie in toenemende mate geconfronteerd met dalende prijzen op de internationale afzetmarkt. Ook in de voeding was sprake van een prijsval ${ }^{7}$. Dit zou de inves-

6 Ook het percentage langdurig openstaande vacatures duidt erop dat de krapte in de sectoren voeding en chemie is afgenomen. Deze percentages zijn tussen 1998 en 1999 gedaald van $21 \%$ naar $18 \%$ (voeding) en $\operatorname{van} 38 \%$ nar $19 \%$ (chemic).

7 Zie Limburgse Sociaal Economische Verkenning 1999, ETIL, Maastricht, 1999. 
teringsneiging ook negatief kunnen beïnvloeden. Het is echter de vraag of de effecten daarvan reeds op zo korte termijn hun beslag hebben gekregen. Bovendien is ook in sectoren waar de arbeidsmarktkrapte is gestegen het antal openstaande vacatures gedaald. Het is dus waarschijnlijk dat jaarlijkse veranderingen in de krapte vooral verklaard kunnen worden door volume-ontwikkelingen in het bestand niet-werkende werkzoekenden, en dan in het bijzonder het direct inzetbare deel daarvan. Overigens betekent de recente daling van de krapte in de sectoren voeding en chemie niet noodzakelijkerwijs dat er geen knelpunten op specifieke deelmarkten kunnen optreden. In met name de sectoren handel, transport en communicatie en kwartaire diensten is de arbeidsmarktkrapte in 1999 in behoorlijke sterke mate verder toegenomen.

Figuur 1.1

Krapte op de Limburgse arbeidsmarkt naar bedrijfssector، 1997-1999

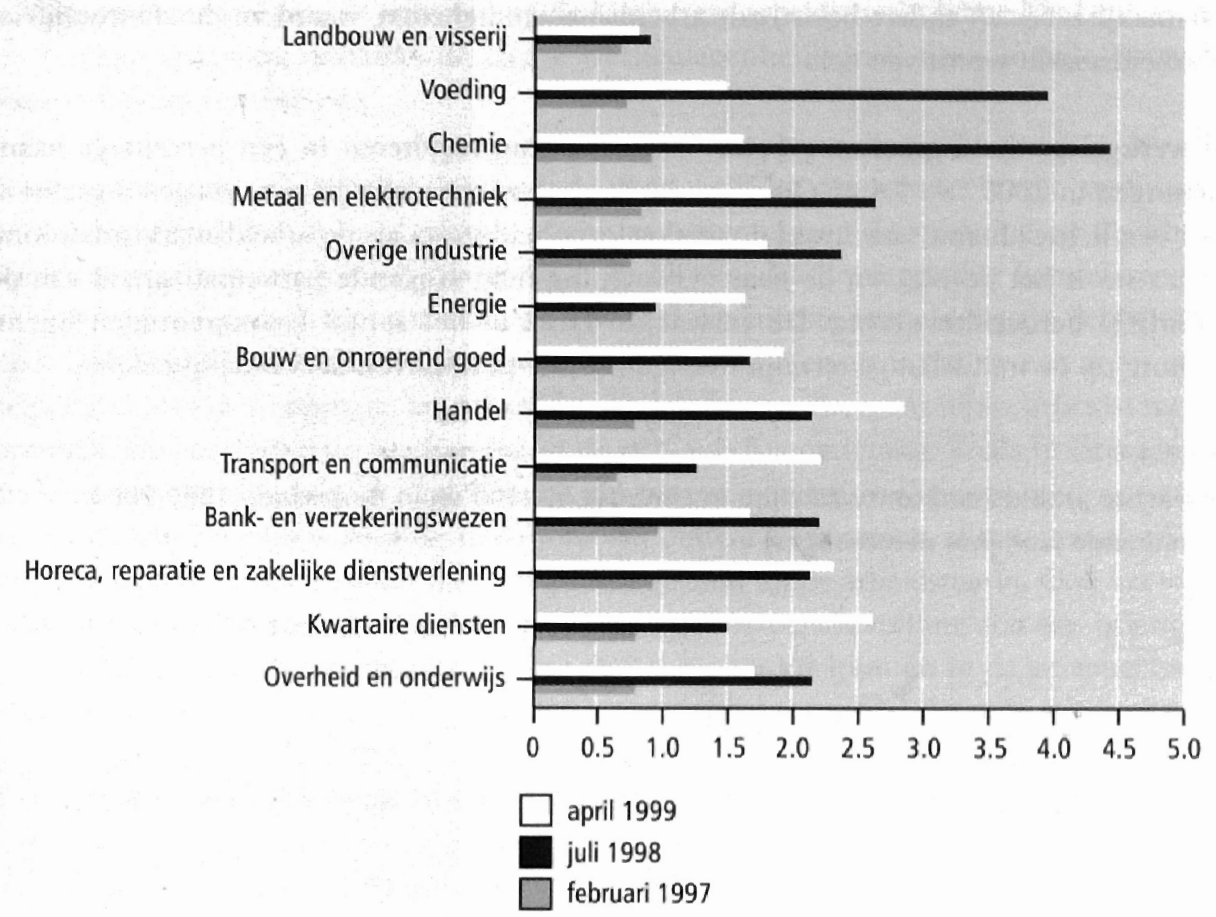

Bron: Arbeidsvoorziening/CBS/ROA

\subsection{De verwachte arbeidsmarktontwikkeling op korte en middellange termijn}

De economische groei die Limburg de laatste jaren doormaakı, zal zich naar verwachting op de korte en middellange termijn voortzetten. Toch zal het groeitempo in het kielzog van de landelijke ontwikkelingen enigszins afzwakken. Vanuit deze optiek is er bij de prognoses van de werkgelegenheidsontwikkelingen op de middellange termijn uilgegaan van het zogenaamde behoedzame scenario van de CPB-prognoses. Zoals tabel 1.4 laat zien, resulteren deze verwachtingen in een werkgelegenheidsgroei in Limburg van $0,7 \%$ in $2000 \mathrm{cn}$ 
gemiddeld 0,5\% voor de periode 1999-2004. Dit betekent een afremming van het hoge groeitempo van de afgelopen jaren. De verwachte werkgelegenheidsgroei in Limburg ligt lager dan de verwachte werkgelegenheidstoename op landelijk niveau. Dit is met name het gevolg van het relatief hoge werkgelegenheidsaandeel van de meer conjunctuurgevoelige industrie in Limburg.

De arbeidsmarktuitstroom vanwege bijvoorbeeld (al dan niet vervroegde) pensionering en arbeidsongeschiktheid zal naar verwachting op de korte en middellange termijn respectievelijk $4,7 \%$ en $4,4 \%$ bedragen. Het laatste percentage ligt daarmee $1 \%$-punt hoger dan het landelijke percentage. De relatief hoge uitstroom hangt, zoals in voorgaande versies van het RAIL-rapport reeds werd aangegeven, samen met de vergrijzing van de Limburgse beroepsbevolking. De hoge arbeidsmarktuitstroom in Limburg is echter niet alleen het gevolg van de snelle vergrijzing van de beroepsbevolking, maar wordt tevens veroorzaakt door het industriële karakter van de werkgelegenheid. In de industrie is vaker sprake van zwaar lichamelijk werk en andere belastende arbeidsomstandigheden, waardoor de uitstroom van de arbeidsmarkt wordt versneld.

De werkgelegenheidsgroei en arbeidsmarktuitstroom resulteren in een percentage baanopeningen in 2000 van $5,4 \%$. Op de middellange termijn vlakt dit percentage enigszins af door een lichte afname van zowel de werkgelegenheidsgroei als de arbeidsmarktuitstroom. Dit laatste is het gevolg van de naar verwachting licht stijgende participatiegraad van de potentiële beroepsbevolking. De verwachte groei in het aantal baanopeningen ligt in Limburg op de middellange termijn overigens $0,5 \%$-punt boven het landelijke cijfer.

Tabel 1.4

Verwachte arbeidsmarktontwikkeling in Limburg in 2000 en in de periode 1999-2004 (gemiddelde jaarlijkse percentages)

\begin{tabular}{|c|c|c|c|}
\hline & $\begin{array}{c}\text { Limburg } 2000 \\
\%\end{array}$ & $\begin{array}{c}\text { Limburg 1999-2004 } \\
\%\end{array}$ & $\begin{array}{c}\text { Nederland 1999-2004 } \\
\%\end{array}$ \\
\hline Werkgelegenheidsgroei & 0,7 & 0,5 & 1,0 \\
\hline Arbeidsmarktuitstroom & 4,7 & 4,4 & 3,4 \\
\hline Baanopeningen & 5,4 & 4,9 & 4,4 \\
\hline Instroom schoolverlaters & 4,2 & 4,2 & 4,2 \\
\hline
\end{tabular}

Bron: TNO//nro/ROA

Het instroompercentage van schoolverlaters in 2000 en in de periode 1999-2004 ligt met $4,2 \%$ duidelijk hoger dan in de vorige korte- en middellange termijn prognoses. Dit houdt verband met een aanpassing in de methodiek. Desalniettemin is er sprake van ontgroening in de zin dat het percentage jongeren in de totale bevolking nog steeds daalt. Verder is in tegenstelling tot de vorige middellange termijnprognoses nu uitgegaan van het behoed-

8 In procenten van het totaal aantal werkenden op de Limburgse arbeidsmarkt. 
zame scenario van het Centraal Planbureau (vorige keer is het gunstige scenario gevolgd wat betreft werkgelegenheidsontwikkelingen). Beide veranderingen laten de conclusie onverlet dat de knelpunten op de Limburgse arbeidsmarkt groot zullen zijn. Uitgaande van de huidige krappe arbeidsmarkt en het gegeven dat de verwachte baanopeningen de verwachte instroom van schoolverlaters overtreffen, zullen de knelpunten op de arbeidsmarkt zich de komende jaren verscherpen. Dit manifesteert zich bij een zeer groot deel van de opleidingen op MBO-niveau of hoger.

Aan de aanbodzijde van de arbeidsmarkt eist de ontgroening zijn tol. Hierdoor neemt het aantal onderwijsvolgenden af. Bovendien volgen jongeren langer een dagopleiding, waardoor hun intrede op de arbeidsmarkt wordt uitgesteld. In 2000 zal de arbeidsmarktinstroom van schoolverlaters $4,2 \%$ bedragen en daarmee fors onder het percentage baanopeningen liggen. Hierbij moet bedacht worden dat dit tekortschietende aanbod bovenop de momenteel reeds bestaande tekorten op de Limburgse arbeidsmarkt komt. Dit betekent dat de huidige spanning ondanks de lagere werkgelegenheidsgroei de komende jaren nog aanzienlijk zal verscherpen.

Naar verwachting zal derhalve de komende jaren, zelfs bij een minder sterke groei van de werkgelegenheid dan in de afgelopen jaren, op macro-niveau de spanning op de arbeidsmarkt nog toenemen. Schoolverlaters zijn en blijven daardoor gewilde kandidaten voor werkgevers die op zoek zijn naar nieuw personeel. De meeste schoolverlaters hebben daardoor gunstige arbeidsmarktperspectieven. De keerzijde hiervan is dat op een groot aantal segmenten van de Limburgse arbeidsmarkt een tekort aan direct inzetbare arbeidskrachten optreedt. Dit zal leiden tot knelpunten in de personeelsvoorziening. Zoals in latere hoofdstukken van dit rapport nader zal worden uitgewerkt, zouden werkgevers op deze ontwikkeling in kunnen spelen door de uitstroom van oudere werknemers af te remmen, of door arbeidskrachten aan te trekken met een grotere afstand tot de arbeidsmarkt. Ook het verder verhogen van de participatiegraad van de Limburgse beroepsbevolking zou een belangrijke rol kunnen spelen bij het voorkomen van de verwachte knelpunten in de personeelsvoorziening.

\subsection{Ontwikkelingen naar bedrijfssector}

Uit tabel 1.5 blijkı dat de positieve ontwikkeling van de werkgelegenheid zich niet in alle bedrijfssectoren manifesteert. In het RAIL-rapport van vorig jaar werd reeds opgemerkt dat er de laatste jaren in Limburg een verschuiving van de werkgelegenheid heeft plaatsgevonden van de industrie naar de commerciële dienstverlening. Op de korte termijn wordt de grootste werkgelegenheidsgroei verwacht voor de sectoren voeding, horeca, reparatie en zakelijke dienstverlening, kwartaire diensten en handel. Daarentegen wordt in 2000 een daling verwacht van de werkgelegenheid in de sectoren chemie, energie, bouw en onroerend goed, overheid en onderwijs, metaal en elektrotechniek, bank-en verzekeringswezen en overige industrie. 


\section{Tabel 1.5}

Ontwikkeling aantal werkenden in Limburg en Nederland per bedrijfssector in 2000 en de periode 1999-2004 (gemiddelde jaarlijkse percentages)

\begin{tabular}{|c|c|c|c|c|}
\hline Bedrijfssector & $\begin{array}{l}\text { aantal } \\
\text { werkenden } \\
1997-1998\end{array}$ & $\begin{array}{c}2000 \\
\text { Limburg } \\
\%\end{array}$ & $\begin{array}{c}1999-2004 \\
\text { Limburg } \\
\%\end{array}$ & $\begin{array}{c}1999-2004 \\
\text { Nederland } \\
\%\end{array}$ \\
\hline Landbouw en visserij & 15.500 & 1,0 & 0,8 & $-1,4$ \\
\hline Voeding & 9.500 & 3,4 & 0,6 & $-0,9$ \\
\hline Chemie & 16.000 & $-1,2$ & $-0,8$ & 0,8 \\
\hline Metaal en elektrotechniek & 44.500 & $-0,6$ & $-0,5$ & $-0,1$ \\
\hline Overige industrie & 36.500 & $-0,1$ & $-0,4$ & $-0,3$ \\
\hline Energie & 5.000 & $-1,0$ & $-0,6$ & $-0,1$ \\
\hline Bouw en onroerend goed & 34.000 & $-0,8$ & $-0,7$ & $-0,6$ \\
\hline Handel & 62.500 & 1,3 & 0,8 & 1,9 \\
\hline Transport en communicatie & 26.500 & 0,3 & 0,0 & 1,2 \\
\hline Bank- en verzekeringswezen & 15.000 & $-0,3$ & $-0,3$ & $-0,2$ \\
\hline Horeca, reparatie en zakelijke dienstverlening & 58.000 & 3,2 & 3,0 & 2,3 \\
\hline Kwartaire diensten & 69.500 & 1,8 & 1,2 & 1,9 \\
\hline Overheid en onderwijs & 61.500 & $-0,8$ & $-0,3$ & 0,4 \\
\hline Totaal & 463.500 & 0,7 & 0,5 & 1,0 \\
\hline
\end{tabular}

Bron: CBS/TNO/Inro/ROA

Op de middellange termijn wordt veruit de grootste groei verwacht voor de horeca, reparatie en zakelijke dienstverlening. In deze sector is de verwachte werkgelegenheidsgroei in Limburg groter dan in de rest van Nederland. De horeca profiteert duidelijk van de toename in welvaart in ons land. Daarbij groeit de werkgelegenheid in de subsector horeca verhoudingsgewijs overigens sneller dan in de subsector toerisme en recreatie ${ }^{9}$. De hoge werkgelegenheidsgroei in de zakelijke dienstverlening is mede het gevolg van het feit dat de uitzendbranche en de detacheringsbedrijven deel uitmaken van deze sector. De flexibilisering van de arbeidsmarkt zorgt voor een toenemende werkgelegenheid in deze bedrijven. Bovendien besteden grote bedrijven steeds vaker hun facilitaire diensten uit aan gespecialiseerde dienstverlenende bedrijven. Men spreekt in dit verband vak van een 'outsourcing' van activiteiten. Belangrijke groeisectoren zijn verder kwartaire diensten en de handel. Opmerkelijk is - gelet op de verdienstelijking van de economie - de verwachte werkgelegenheidsgroei in de sectoren landbouw en visserij en voeding. Op landelijk niveau is er voor deze sectoren op middellange termijn dan ook sprake van een daling in de werkgelegenheid. Daarentegen is de verwachte werkgelegenheidsontwikkeling in de industriële sectoren in Limburg ongunstiger dan de landelijke ontwikkeling. Voor alle industriesectoren wordt een krimpende werkgelegenheid verwacht. Voor een deel is dit het gevolg van de verwachte minder gunstige conjuncturele ontwikkeling. Voor een ander deel is de werkgelegenheidsdaling in de industrie het gevolg van de toename van de arbeidsproductiviteit

9 Zie Sectorrapportage horeca, toerisme \& recreatic, ETIL, Maastricht, 1999. 
vanwege vernieuwingen in het productieproces. Dit is met name het geval in de chemie en de metaal en elektrotechniek. De verwachte afname van de werkgelegenheid in de bouwsector is vooral toe te schrijven aan het hier gevolgde behoedzame scenario van het Centraal Planbureau en de verwachte stagnerende groei van de bouwproductie.

Tabel 1.6 geeft voor de diverse bedrijfssectoren een overzicht van de opleidingstypen op VMBO- en MBO-niveau waarvoor de sector op de middellange termijn geconfronteerd

Tabel 1.6

(Zeer) grote knelpunten in de personeelsvoorziening naar bedrijfssector in Limburg in 2004

Bedrijfssector

Landbouw en visserij

Voeding

Chemie

Overige industrie

Bouw en onroerend goed

Handel

Transport en communicatie

Horeca, reparatie en zakelijke dienstverlening

Kwartaire diensten

Overheid en onderwijs
Verwachte knelpunten

MBO landbouw en veeteelt

MBO milieu en groene ruimte

MBO levensmiddelentechniek/vleesverwerking

MBO procestechniek

MBO milieu en groene ruimte

VMBO elektrotechniek

VMBO theorie*

VMBO elektrotechniek

VMBO (uiterlijke) verzorging

HAVO/NWO

$\mathrm{MBO}$ landbouw en veeteelt

MBO levensmiddelentechniek/vleesverwerking

$M B O$ vervoer en logistiek

MBO gezondheidstechniek

MBO uiterlijke verzorging

MBO administratie

MBO handel

$M B O$ secretariaat

MBO vervoer en logistiek

$\mathrm{MBO}$ toerisme en recreatie

HAVONWO

$\mathrm{MBO}$ administratie

MBO secretariaat

VMBO (uiterlijke) verzorging

$M B O$ verpleging

$M B O$ verzorging

$\mathrm{MBO}$ uiterlijke verzorging

$M B O$ secretariaat

$M B O$ milieu en groene ruimte

$\mathrm{MBO}$ administratie

MBO openbare orde en veiligheid

\footnotetext{
* In dit rapport is gebruik gemaakt van de meest recente benaming VMBO theorie in plaats van MAVO Bron: ROA
} 
wordt met (zeer) grote knelpunten in de personeelsvoorziening ${ }^{10}$. De toekomstige knelpunten op de arbeidsmarkt blijken vooral geconcentreerd te zijn in de tertiaire en kwartaire sector, in het bijzonder in de handel en de kwartaire diensten. Daarnaast kampt ook de agrarische sector met knelpunten bij het aantrekken van mensen met een middelbare beroepsopleiding. Hetzelfde geldt voor de chemie, die kampt met problemen bij het werven van MBO'ers procestechniek.

Wél moet benadrukt worden dat werkgevers bij de werving van nieuw personeel bij verschillende beroepsgroepen de mogelijkheid hebben om arbeidskrachten met een uiteenlopende opleidingsachtergrond aan te trekken. Deze substitutiemogelijkheden zullen in de praktijk worden aangegrepen om wervingsproblemen te verlichten. In sommige gevallen zal dit echter gepaard moeten gaan met het bijscholen of omscholen van mensen met een andere opleidingsachtergrond. Met name voor een aantal beroepen in de kwartaire diensten lijkt deze flexibiliteit echter nauwelijks te bestaan, aangezien deze beroepen zeer specifieke kennis en vaardigheden vereisen en de werkenden in deze beroepen veelal een specifieke opleidingsachtergrond moeten hebben. Voor bijvoorbeeld de verplegende beroepen zullen de knelpunten in de personeelsvoorziening waarschijnlijk nijpend zijn. Ook de tekorten aan mensen met een opleiding $M B O$ handel, $M B O$ economie en $M B O$ secretariaat zullen naar verwachting groot zijn. Voor werkgevers die kampen met problemen bij het aantrekken van arbeidskrachten met een dergelijke opleidingsachtergrond zijn er immers weinig alternatieven voorhanden voor wat betreft het werven van mensen met een andere opleidingsachtergrond waarnaar zij zouden kunnen uitwijken.

\subsection{Ontwikkelingen naar beroepssector}

De veranderingen in de werkgelegenheidsstructuur naar bedrijfssector beinvloeden de ontwikkeling van de werkgelegenheid in de verschillende beroepssectoren. Maar ook de verschuivingen in de beroepenstructuur binnen dé verschillende bedrijfssectoren leiden vaak tot een sterk uiteenlopende werkgelegenheidsgroei in de verschillende beroepen ${ }^{\text {". In }}$ tabel 1.7 wordt een overzicht gegeven van de ontwikkeling van het aantal werkenden in de verschillende beroepssectoren. Ook deze cijfers illustreren de verdergaande verdienstelijking van de Limburgse economie.

10 Voor (bijna) alle bedrijfssectoren geldt overigens dat het werven van mensen met een $\mathrm{HBO}$ - en WO-opleiding zeer problematisch is. Gezien het landelijke karakter van het arbeidsaanbod van deze groep is hieraan in de tabel echter geen aandacht besteed.

11 Dit biedt bijvoorbeeld een verklaring van de verwachte daling in de werkgelegenheid voor de agrarische beroepen, terwijl de sector landbouw en visserij een werkgelegenheidsgroei laat zien. Onder de agrarische beroepen valt bijvoorbeeld de beroepsgroep milieuhygiennisten en agrarisch vertegenwoordigers. Deze mensen zijn echter veelal buiten de sector landbouw en visserij werkzaam. 
Tabel 1.7

Ontwikkeling aantal werkenden in Limburg per beroepssector in 2000 en de periode 1999-2004 (gemiddelde jaarlijkse percentages)

\begin{tabular}{|c|c|c|c|c|}
\hline Beroepssector & $\begin{array}{l}\text { aantal } \\
\text { werkenden } \\
1997-1998\end{array}$ & $\begin{array}{c}2000 \\
\text { Limburg } \\
\%\end{array}$ & $\begin{array}{c}1999-2004 \\
\text { Limburg } \\
\%\end{array}$ & $\begin{array}{c}1999-2004 \\
\text { Nederland } \\
\%\end{array}$ \\
\hline Pedagogische beroepen & 23.500 & $-0,6$ & $-0,3$ & 1,0 \\
\hline Culturele beroepen & 5.000 & $-1,4$ & $-0,3$ & 1,0 \\
\hline Agrarische beroepen & 18.500 & $-2,0$ & $-1,1$ & $-1,5$ \\
\hline Technische en industrieberoepen & 121.500 & $-1,1$ & $-4,6$ & $-3,0$ \\
\hline Transportberoepen & 28.000 & 0,8 & $-0,8$ & 0,5 \\
\hline Medische en paramedische beroepen & 25.500 & $-0,1$ & $-0,3$ & 0,5 \\
\hline Economisch-administratieve beroepen & 121.000 & 2,0 & 3,4 & 3,3 \\
\hline Informaticaberoepen & 8.500 & 6,5 & 7,5 & 4,7 \\
\hline Sociaal-culturele beroepen & 12.000 & $-0,3$ & 1,4 & 2,5 \\
\hline Verzorgende en dienstverl. beroepen & 80.000 & 2,4 & 3,2 & 1,8 \\
\hline Openbare orde en veiligheidsberoepen & 7.000 & $-2,2$ & $-1,4$ & 0,0 \\
\hline Totaal (inclusief beroep onbekend) & 463.500 & 0,7 & 0,5 & 1,0 \\
\hline
\end{tabular}

Bron: CBS/ROA

Voor het jaar 2000 wordt - net als in de vorige voorspelling voor 1999 - de sterkste groei verwacht voor de informaticaberoepen. Verder is er groei in de verzorgende en dienstverlenende, de economisch-administratieve en de transportberoepen. Een duidelijke daling van de werkgelegenheid wordt daarentegen verwacht voor de agrarische beroepen alsmede voor de openbare orde en veiligheidsberoepen. Ook in de culturele beroepen en in de technische en industrieberoepen is er sprake van enige daling.

Op middellange termijn blijft dit beeld in grote lijnen bestaan. Voor de krimpberoepen zal de krimp naar verwachting iets alzwakken, met uitzondering van de technische en industrieberoepen en de medische en paramedische beroepen. Met name voor de technische en industrieberoepen wordt er een forse werkgelegenheidskrimp verwacht. Daarentegen wordt een sterke groei verwacht van de werkgelegenheid in de economisch-administratieve beroepen. Het sterkst is de verwachte werkgelegenheidsgroei voor de informaticaberoepen. Het jaarlijkse groeipercentage van het aantal werkenden in de informaticaberoepen stijgt zelfs van $6,5 \%$ naar $7,5 \%$. Ook landelijk gezien blijken de economisch-administratieve en de informaticaberoepen het sterkst te groeien. 


\subsection{Ontwikkelingen naar opleidingssector}

Door het totaal van de verwachte baanopeningen te confronteren met de verwachte arbeidsmarktinstroom en de direct inzetbare niet-werkende werkzoekenden wordt een indicatie verkregen van de arbeidsmarktperspectieven per opleidingstype. Tabel 1.8 geeft een overzicht van de verwachte uitbreidingsvraag, vervangingsvraag en arbeidsmarktinstroom van schoolverlaters, alsmede van de arbeidsmarktperspectieven voor de verschillende opleidingssectoren ${ }^{12}$. Deze perspectieven worden gekwantificeerd aan de hand van de Indicator Toekomstige Arbeidsmarktperspectieven (ITA) ${ }^{13}$. Wanneer de ITA kleiner is dan 1, overtreft de vraag het arbeidsaanbod met de betreffende opleidingsachtergrond en is het toekomstig perspectief gunstiger.

\section{Tabel 1.8}

Uitbreidingsvraag, vervangingsvraag en instroom van schoolverlaters (gemiddelde jaarlijkse percentages) en de daaruit voortvloeiende toekomstige arbeidsmarktperspectieven per opleidingssector in Limburg, 1999-2004

\begin{tabular}{lccccc} 
Opleidingssector & $\begin{array}{c}\text { uitbreidings- } \\
\text { vraag } \\
\%\end{array}$ & $\begin{array}{c}\text { vervangings- } \\
\text { vraag } \\
\%\end{array}$ & $\begin{array}{c}\text { arbeidsmarkt- } \\
\text { instroom } \\
\%\end{array}$ & $\begin{array}{c}\text { ITA } \\
2004\end{array}$ & $\begin{array}{l}\text { typering } \\
\text { ITA }\end{array}$ \\
\hline Basisonderwijs & $-4,0$ & 4,0 & 4,2 & 1,02 & redelijk \\
VMBO Theorie & 1,6 & 5,1 & 4,4 & 0,94 & goed \\
VMBO Landbouw en techniek & $-3,9$ & 4,3 & 3,1 & 0,96 & goed \\
VMBO Economie & $-0,9$ & 4,8 & 6,1 & 1,11 & matig \\
VMBO Verzorging & 0,9 & 5,4 & 3,4 & 0,90 & goed \\
HAVO/NWO & 3,4 & 5,5 & 6,9 & 0,95 & goed \\
MBO Landbouw en techniek & $-0,8$ & 3,5 & 3,3 & 0,98 & goed \\
MBO Economie & 1,5 & 3,4 & 4,0 & 0,97 & goed \\
MBO Dienstverlening en gez.zorg & 1,2 & 3,9 & 4,3 & 0,98 & goed
\end{tabular}

Bron: $R O A$

Uit de tabel blijkt dat de vraagontwikkeling sterk uiteenloopt tussen de verschillende opleidingssectoren. Zo wordt er een forse daling verwacht van de vraag naar mensen die alleen Basisonderwijs of VMBO Landbouw en techniek hebben gevolgd. Opvallend is de aanzienlijke uitbreidingsvraag voor schoolverlaters met een $\mathrm{HAVO} / \mathrm{VWO}$-diploma. Met uitzondering van de opleidingssector MBO Landbouw en techniek is de verwachte uitbreidingsvraag voor de opleidingen op MBO-niveau positief. De vervangingsvraag laat tussen de verschillende opleidingssectoren een minder grote variatie zien en ligı tussen 3,4\% voor MBO Economie en $5,5 \%$ voor HAVO/VWO. Deze opleidingssector kent ook de grootste arbeidsmarktin-

12 Het HBO en WO worden hierbij buiten beschouwing gelaten. De perspectieven voor opleidingen op dit niveau zijn over het algemeen (zeer) goed.

13 In hoofdstuk 4 wordt een nadere uitleg gegeven van deze indicator en de daaruit afgeleide typering van de toekomstige arbeidsmarktperspectieven voor een bepaald opleidingstype. 
stroom met 6,9\%. Ook voor VMBO Economie, VMBO Theorie en MBO Dienstverlening en gezondheidszorg is de arbeidsmarktinstroom relatief hoog.

Voor maar liefst 7 van de 9 in tabel 1.8 onderscheiden opleidingssectoren is er sprake van goede arbeidsmarktperspectieven. Duidelijk minder positief zijn de vooruitzichten voor mensen met alleen Basisonderwijs of een opleiding VMBO Economie. Vanuit werkgeversoogpunt betekenen de goede arbeidsmarktperspectieven voor nieuwkomers op de arbeidsmarkt dat er ook op de middellange termijn knelpunten zullen blijven optreden in de personeelsvoorziening. Het aanbod van direct inzetbare arbeidskrachten blijft de komende jaren kleiner dan het aantal baanopeningen. Dit betekent dat werkgevers problemen zullen blijven ondervinden bij het aantrekken van nieuw personeel. Het voortduren van de arbeidsmarktknelpunten kan een bedreiging vormen voor de economische groei in de provincie $^{1+}$.

\subsection{De participatiegraad in Limburg}

Voor het verminderen van de knelpunten op de arbeidsmarkt is een optimaal opleidingsaanbod in het initiële en niet-initiële onderwijs van groot belang. Daarnaast is een adequaat 'curatief' bij- en omscholingsbeleid gericht op het niet-direct inzetbare aanbod van (langdurig) niet-werkende werkzoekenden van grote betekenis voor het voorkomen van knelpunten in de personeelsvoorziening. Ook het stimuleren van de arbeidsmarktparticipatie in het algemeen kan een belangrijke bijdrage leveren aan het vergroten van het aanbod van gekwalificeerd personeel.

Tabel 1.9 geeft een beeld van de omvang van de non-participatie, verbijzonderd naar geslacht en leeftijd. Uit de tabel blijkt dat de arbeidsparticipatie onder de oudere arbeidskrachten in Limburg zeer laag is. Van de bevolking tussen de 50 en 64 jaar biedt bijna $60 \%$ zich niet (meer) aan op de arbeidsmarkt. De kans is groot dat zij door vervroegde uittreding of arbeidsongeschiktheid de arbeidsmarkt reeds definitief hebben verlaten. In dat geval zal het waarschijnlijk aanzienlijke investeringen vergen deze groep te activeren en (opnieuw) klaar te stomen voor de arbeidsmarkt. Dit roept de vraag op in hoeverre deze investeringen opwegen tegen de baten, gezien het feit dat de periode gedurende welke de investeringen rendement op kunnen leveren kort zal zijn.

Minder verrassend is dat de arbeidsmarktparticipatie onder mannen veel hoger is dan onder vrouwen. Slechts 16\% van de Limburgse mannen tussen de 15 en de 64 jaar heeft geen werk en zoekt ook niet actief naar werk. Bij de vrouwen is dit percentage veel hoger, namelijk $48 \%$. Geconcludeerd kan worden dat er vanuit een macro-optiek duidelijk mogelijkheden bestaan om via een verhoging van de participatiegraad de krapte op de Limburgse arbeidsmarkt te verminderen. Met name door de participatie van vrouwen te stimuleren kan het aanbod op de Limburgse arbeidsmarkt worden vergroot. In hoofdstuk 6 zal hierop nader worden ingegaan.

14 Uit prognoses van het Nederlands Economisch Instituut blijkt dat de verwachte gemiddelde jaarlijkse groeivoet van de Limburgse economie in de periode 1999-2003 2, I bedraagt. Dit percentage ligt enigszins onder de vorige prognose uit 1998 die voor de periode 1996-2002 een jaarlijkse groei van 2,6\% voorspelde. Zie European Regional Prospects, Analysis and Forecasts to 2003, NEI, Rotterdam, 1999. 
Tabel 1.9

Non-participatie naar geslacht en leeftijd, Limburg, gemiddelde 1997-1998

\begin{tabular}{lrrr} 
& \multicolumn{2}{c}{$\begin{array}{l}\text { totaal } \\
\text { aantal }\end{array}$} & \multicolumn{2}{c}{$\begin{array}{l}\text { niet-participerend } \\
\text { aantal }\end{array}$} & $\%$ \\
\hline $\begin{array}{l}\text { mannen } \\
\text { vrouwen }\end{array}$ & 354.500 & 57.000 & 16 \\
& 341.000 & 163.500 & 48 \\
jonger dan 30 jaar & 126.500 & & 12 \\
30-50 jaar & 367.500 & 15.000 & 24 \\
ouder dan 50 jaar & 201.500 & 86.500 & 58 \\
totaal & & 117.000 & 32 \\
\hline
\end{tabular}

Bron: CBS/ROA 


\section{Actuele discrepanties op de Limburgse arbeidsmarkt}

In dit hoofdstuk wordt de actuele situatie op de Limburgse arbeidsmarkt belicht. De krapte op de arbeidsmarkt is het geringst in de sector landbouw en visserij. Hier is zelfs sprake van een ruime arbeidsmarkt. In alle andere bedrijfssectoren is er duidelijk sprake van een krappe arbeidsmarkt. De krapte is het grootst in de dienstensectoren. In de sector handel zijn er per 100 niet-werkende werkzoekenden in fase 1 maar liefst 284 openstaande vacatures beschikbaar. Ook in een groot aantal beroepssegmenten is sprake van een krappe arbeidsmarkt. De arbeidsmarktkrapte is het grootst in de hogere (para)medische beroepen en de lagere beveiligingsberoepen. Voor de meeste beroepssegmenten is het tekort kwalitatief van aard. In dat geval is er weliswaar een tekort aan direct bemiddelbare werkzoeken, maar voldoende aanbod van arbeidskrachten met een wat grotere afstand tot de arbeidsmarkt. Kwantitatieve tekorten zijn er bij de lagere verzorgende beroepen, de lagere administratieve, commerciële en economische beroepen, de lagere agrarische beroepen, de lagere beveiligingsberoepen en de hogere (para)medische beroepen. Voor de opleidingssectoren VMBO Economie, Basisonderwijs, HAVO/VWO, VMBO Theorie en VMBO Verzorging is er sprake van een ruime arbeidsmarkt. Kwalitatieve aansluitingsproblemen bestaan vooral bij de technische en verzorgende opleidingen op lager en middelbaar niveau. Over het algemeen worden de middelbare en hogere opleidingen gekenmerkt door een kwantitatief tekort.

Meer specifieke cijfers voor de actuele arbeidsmarktpositie van schoolverlaters laten zien dat in het afgelopen jaar de positie van schoolverlaters op MBO-niveau aanzienlijk is verbeterd. Dit geldt echter niet voor alle opleidingssectoren in even sterke mate. Zo is de werkloosheid relatief hoog onder de schoolverlaters van de opleidingssector MBO Landbouw en natuurlijke omgeving. De werkloosheid is voor deze opleidingssector in Limburg ook veel hoger dan in de rest van Nederland. Het werkloosheidspercentage voor MBO Techniek is daarentegen in Limburg lager dan landelijk. Daarnaast blijken schoolverlaters van MBO Techniek en MBO Economie in Limburg gemiddeld genomen meer te verdienen dan landelijk. Voor MBO Economie is het verschil in bruto maandsalaris tussen de Limburgse schoolverlaters en de schoolverlaters in de rest van Nederland echter het grootst.

\subsection{Inleiding}

In dit hoofdstuk zal de actuele situatie op de Limburgse arbeidsmarkt nader worden belicht. De omvang en samenstelling van de openstaande vacatures en het aanbod van nietwerkende werkzoekenden staan hierbij centraal. Daarnaast zal worden beschreven op welke arbeidsmarktsegmenten er sprake is van kwantitatieve of kwalitatieve discrepanties tussen vraag en aanbod. Er wordt getracht een antwoord te geven op twee vragen:

- in hoeverre zijn er op dit moment voldoende geschikte niet-werkende werkzoekenden beschikbaar om de openstaande vacatures te vervullen?

in hoeverre zijn er voldoende openstaande vacatures om de niet-werkende werkzoekenden aan een baan te helpen?

Eerst wordt in paragraaf 2.2 aandacht besteed aan de openstaande vacatures. Een overzichı van de niet-werkende werkzoekenden komt vervolgens in paragraaf 2.3 aan de orde. In paragraaf 2.4 worden de openstaande vacatures en de niet-werkende werkzoekenden met elkaar geconfronteerd om inzicht te krijgen in de actuele discrepanties op de Limburgse 
arbeidsmarkt. In de afsluitende paragraaf zal worden gekeken naar de actuele arbeidsmarktpositie van de schoolverlaters van het secundair beroepsonderwijs (MBO).

\subsection{Openstaande vacatures in Limburg}

Een overzicht van de openstaande vacatures biedt per definitie een momentopname van de mogelijke knelpunten die er aan de vraagzijde van de arbeidsmarkt optreden. In deze paragraaf worden twee indicatoren gepresenteerd:

- de vacaturegraad: het aantal openstaande vacatures per 1.000 werkenden;

- het percentage langdurig (langer dan 3 maanden) openstaande vacatures.

Een lage vacaturegraad wijst erop dat de vereiste rekruteringsinspanningen relatief gering zijn. Dit betekent echter niet dat er geen knelpunten op specifieke deelterreinen van de markt kunnen bestaan. Om dit te kunnen beoordelen, moet naast de vraag ook naar het aanbod van nieuwkomers worden gekeken. Wat dat betreft vormt het percentage langdurig openstaande vacatures een meer direct signaal voor het bestaan van rekruteringsproblemen.

Wanneer zowel de vacaturegraad als het percentage langdurig openstaande vacatures hoog is, is er waarschijnlijk sprake van ernstige knelpunten in de personeelsvoorziening. In dat geval hebben bedrijven niet alleen veel moeite met het vervullen van vacatures, maar zijn de gevolgen van het openstaan van het grote aantal vacatures bovendien sterk merkbaar in het productieproces. De rekrutering van personeel staat bij deze bedrijven dan ook onder grote druk. Wanneer een lage vacaturegraad gepaard gaat met een laag percentage langdurig openstaande vacatures, hebben bedrijven niet alleen relatief weinig moeite met het vervullen van vacatures; ook de gevolgen van het openstaan van deze vacatures zijn waarschijnlijk gemakkelijker op te vangen.

\section{Openstaande vacatures naar beroepssegment}

Een overzicht van de openstaande vacatures naar beroepssegment laat zien waar de rekruteringsproblemen op de arbeidsmarkt zich met name voordoen. In tabel 2.1 wordt aangegeven welke beroepssegmenten gekenmerkt worden door een hoge tot zeer hoge vacaturegraad. De hoogste vacaturegraden worden gevonden bij de lagere verzorgende en de elementaire beroepen. Dat de vacaturegraad vooral bij lagere beroepen groot blijkt te zijn, kan twee oorzaken hebben. Enerzijds is de vervangingsvraag als gevolg van arbeidsmarktuitstroom in de lagere beroepen vaak hoger. Anderzijds worden vacatures voor hogere functies vaak via interne promoties opgevuld waardoor er zogenaamde vacatureketens ontstaan die

Tabel 2.1

Beroepssegmenten met een hoge tot zeer hoge vacaturegraad in Limburg, april 1999

\begin{tabular}{|c|c|c|c|c|c|}
\hline Beroepssegment & vacaturegraad & typering & langdu & openstaand & typering \\
\hline & $\%$ & & aantal & $\%$ & \\
\hline Lagere verzorgende beroepen & 150 & zeer hoog & 425 & 24 & laag \\
\hline Elementaire beroepen & 65 & hoog & 525 & 25 & laag \\
\hline
\end{tabular}

Bron: Arbeidsvoorziening/CBS/ROA 
uiteindelijk leiden tot een externe vacature in een lagere functie. Toch zijn de rekruteringsproblemen in deze twee beroepssegmenten niet excessief, gelet op het lage percentage vacatures dat langdurig openstaat.

Tabel 2.2 geeft een beeld van de beroepssegmenten waarvoor de vacaturegraad laag tot zeer laag is. Het betreft hier beroepssegmenten op middelbaar niveau, over een breed spectrum van de arbeidsmarkt. De lage vacaturegraad voor de beroepssegmenten op middelbaar niveau is waarschijnlijk het gevolg van het feit dat de uitbreidingsvraag achterblijft ten opzichte van beroepssegmenten op hoger niveau. Ernstige rekruteringsproblemen zullen bij de beroepssegmenten die in tabel 2.2 genoemd staan niet of nauwelijks optreden, ook al is het percentage langdurig openstaande vacatures voor een tweetal segmenten hoog.

Tabel 2.2

Beroepssegmenten met een lage tot zeer lage vacaturegraad in Limburg, april 1999

\begin{tabular}{|c|c|c|c|c|c|}
\hline \multirow[t]{2}{*}{ Beroepssegment } & \multirow{2}{*}{$\begin{array}{c}\text { vacaturegraad } \\
\% 00\end{array}$} & \multirow[t]{2}{*}{ typering } & \multicolumn{2}{|c|}{ langdurig openstaand } & \multirow[t]{2}{*}{ typering } \\
\hline & & & aantal & $\%$ & \\
\hline Middelbare agrarische beroepen & 13 & laag & 50 & 42 & hoog \\
\hline Middeibare (para-)medische beroepen & 14 & laag & 100 & 47 & hoog \\
\hline Middelbare verzorgende beroepen & 19 & laag & 75 & 25 & laag \\
\hline Middelbare adm., comm., ec. beroepen & 23 & laag & 550 & 37 & gemiddeld \\
\hline Middelbare technische beroepen & 25 & laag & 525 & 41 & gemiddeld \\
\hline
\end{tabular}

Bron: Arbeidsvoorziening/CBS/ROA

\section{Openstaande vacatures naar opleidingssector}

Een overzicht van de openstaande vacatures naar opleidingssector geeft inzicht in de problemen die ondervonden worden bij het vinden van personeel met een bepaalde opleidingsachtergrond. Tabel 2.3 geeft een beeld van de opleidingssectoren die gekenmerkt worden door een hoge tot zeer hoge vacaturegraad. De tabel laat zien dat de opleidingen met een (zeer) hoge vacaturegraad niet geconcentreerd zijn in een bepaalde vakrichting of

Tabel 2.3

Opleidingssectoren met een hoge tot zeer hoge vacaturegraad in Limburg, april 1999

\begin{tabular}{|c|c|c|c|c|c|}
\hline Opleidingssector & vacaturegraad & typering & langdu & enstaand & typering \\
\hline & $\%$ & & aantal & $\%$ & \\
\hline VMBO Techniek & 69 & zeer hoog & 625 & 25 & laag \\
\hline MBO Economie & 38 & hoog & 425 & 19 & zeer laag \\
\hline VMBO Landbouw en nat. omg. & 34 & hoog & 50 & 37 & gemiddeld \\
\hline HBO Techniek & 33 & hoog & 200 & 54 & hoog \\
\hline VMBO Verzorging & 33 & hoog & 250 & 44 & hoog \\
\hline
\end{tabular}

Bron: Arbeidsvoorziening/CBS/ROA 
op een bepaald opleidingsniveau. Wel werd vorig jaar reeds gesteld dat de nadruk lijkt te liggen op opleidingssectoren in de technische richting. De vacaturegraad is het hoogst voor de opleidingssector VMBO Techniek. Ook bij HBO Techniek is de vacaturegraad hoog. Bij HBO Techniek en VMBO Verzorging wijzen de beide indicatoren dezelfde kant op. Dit duidt op aanzienlijke rekruteringsproblemen.

Tabel 2.4 laat zien voor welke opleidingssectoren de vacaturegraad laag of zeer laag is. De opleidingssectoren met de laagste vacaturegraden hebben een aantal gemeenschappelijke kenmerken: een relatief laag opleidingsniveau en/of een relatief algemeen/breed karakter. De tabel illustreert de upgrading van de opleidingseisen die er op de arbeidsmarkt plaatsvindt. Dit leidt ertoe dat de vraag naar mensen die slechts over lagere kwalificaties beschikken afneemt. Bij deze opleidingssectoren ligt het percentage vacatures dat langdurig openstaat op een gemiddeld niveau.

Tabel 2.4

Opleidingssectoren met een lage tot zeer lage vacaturegraad in Limburg, april 1999

\begin{tabular}{|c|c|c|c|c|c|}
\hline \multirow[t]{2}{*}{ Opleidingssector } & \multirow{2}{*}{$\begin{array}{c}\text { vacaturegraad } \\
\% 0\end{array}$} & \multirow[t]{2}{*}{ typering } & \multicolumn{2}{|c|}{ langdurig openstaand } & \multirow[t]{2}{*}{ typering } \\
\hline & & & aantal & $\%$ & \\
\hline Basisonderwijs & 4 & zeer laag & - & - & - \\
\hline VMBO Economie & 8 & laag & - & - & - \\
\hline HAVONWWO & 13 & laag & 75 & 29 & gemiddeld \\
\hline MBO Dienstverl. en gez.h.zorg & 17 & laag & 275 & 33 & gemiddeld \\
\hline MBO Landbouw en nat. omg. & 17 & laag & 50 & 39 & gemiddeld \\
\hline
\end{tabular}

Bron: Arbeidsvoorziening/CBS/ROA

\subsection{Niet-werkende werkzoekenden in Limburg}

\section{Niet-werkende werkzoekenden naar beroepssegment}

Wanneer een werkzoekende zich inschrijft bij het arbeidsbureau, wordt onder andere het wensberoep geregistreerd. Dit maakt het mogelijk inzicht te krijgen in de verdeling van de niet-werkende werkzoekenden over de verschillende beroepssegmenten. In tabel 2.5 wordt een overzicht gegeven van de beroepssegmenten waarin er sprake is van een hoog tot zeer hoog percentage niet-werkende werkzoekenden. Het gaat hier vooral om beroepssegmenten op elementair en lager niveau. Dit wijst erop dat voor veel functies een opleiding op tenminste middelbaar niveau vereist is. Het meest dramatisch is de situatie voor de elementaire beroepen, met niet alleen een extreem hoog werkloosheidspercentage van $25,6 \%$, maar ook een hoog percentage langdurig werkzoekenden van maar liefst $63 \%$. Opmerkelijk is ten slotte het relatief grote aantal niet-werkende werkzoekenden dat op zoek is naar een managementfunctie op HBO-niveau. 
Tabel 2.5

Beroepssegmenten met een hoog tot zeer hoog aantal niet-werkende werkzoekenden als percentage van de beroepsbevolking in Limburg, april 1999

\begin{tabular}{|c|c|c|c|c|c|}
\hline \multirow[t]{2}{*}{ Beroepssegment } & \multirow{2}{*}{$\begin{array}{c}\text { werkloosheid } \\
\%\end{array}$} & \multirow[t]{2}{*}{ typering } & \multicolumn{2}{|c|}{ langdurig werkzoekend } & \multirow{2}{*}{ typering } \\
\hline & & & aantal & $\%$ & \\
\hline Elementaire beroepen & 25,6 & zeer hoog & 6.875 & 63 & hoog \\
\hline Lagere verzorgende beroepen & 16,3 & zeer hoog & 1.150 & 51 & gemiddeid \\
\hline Lagere transportberoepen & 10,4 & hoog & 1.125 & 49 & gemiddeld \\
\hline Managers ( $\mathrm{HBO}$ werk- en denkniveau) & 9,7 & hoog & 150 & 56 & gemiddeld \\
\hline
\end{tabular}

Bron: Arbeidsvoorziening/ROA

Tabel 2.6 laat zien dat vooral beroepssegmenten op tenminste middelbaar niveau profiteren van de gunstige situatie op de arbeidsmarkt. Het gaat dan met name om beroepssectoren met een medisch of economisch karakter. Het lage percentage werklozen voor de lagere agrarische beroepen is wat dat betreft opvallend. Dit hangt waarschijnlijk samen met het meetmoment (april) van de werkzoekendencijfers. Verder valt het hoge percentage langdurig werkzoekenden op voor de beroepssegmenten managers (WO-niveau) en wetenschappelijke juridische, bestuurlijke beroepen.

Tabel 2.6

Beroepssegmenten met een laag tot zeer laag aantal niet-werkende werkzoekenden als percentage van de beroepsbevolking in Limburg, april 1999

Beroepssegment werkloosheid typering langdurig werkzoekend typering $\%$ aantal \%

Hogere (para)medische beroepen

$\begin{array}{llrll}1,0 & \text { zeer laag } & 25 & 45 & \text { laag } \\ 1,7 & \text { zeer laag } & 75 & 59 & \text { hoog } \\ 2,4 & \text { laag } & 275 & 49 & \text { gemiddeld } \\ 2,5 & \text { laag } & 25 & 35 & \text { zeer laag } \\ 2,8 & \text { laag } & 50 & 60 & \text { hoog } \\ 2,9 & \text { laag } & 125 & 55 & \text { gemiddeld }\end{array}$

Bron: Arbeidsvoorziening/ROA

\section{Niet-werkende werkzoekenden naar opleidingssector}

In tabel 2.7 wordt een overzicht gegeven van de opleidingssectoren die gekenmerkt worden door een hoog tot zeer hoog percentage niet-werkende werkzoekenden ${ }^{15}$. Het gaat hier zonder uitzondering om mensen met weinig opleiding. Bij VMBO Theorie spelen waar-

15 Bij het bepalen van iemands opleidingsachtergrond is ook met de na het dagonderwijs geıolgde scholing rekening gehouden. 
schijnlijk twee zaken een rol. Enerzijds wordt de arbeidsmarktpositie van werkzoekenden met een 'algemene' opleiding verzwakt omdat vacatures vaak worden gesteld in termen van redelijk nauw omschreven opleidingseisen, waaraan mensen met een meer gespecialiseerde opleidingsachtergrond veelal beter voldoen. Anderzijds verbetert een brede opleiding iemands arbeidsmarktomstandigheden wanneer de economische situatie in bepaalde marktsegmenten slecht is, omdat het iemand in staat stelt een breder scala aan beroepen te bestrijken. Men heeft dus betere mogelijkheden over te stappen naar segmenten waar de markt verhoudingsgewijs goed is. Wanneer een opleiding zowel een laag niveau heeft als een algemeen karakter, dan zal het eerstgenoemde effect waarschijnlijk het grootst zijn.

\section{Tabel 2.7}

Opleidingssectoren met een hoog tot zeer hoog aantal niet-werkende werkzoekenden als percentage van de beroepsbevolking in Limburg, april 1999

\begin{tabular}{|c|c|c|c|c|c|}
\hline Opleidingssector & werkloosheid & typering & langdur & werk & nd typering \\
\hline & $\%$ & & aantal & $\%$ & \\
\hline VMBO Economie & 24,6 & zeer hoog & 1.700 & 57 & gemiddeld \\
\hline VMBO Verzorging & 21,6 & zeer hoog & 2.975 & 64 & zeer hoog \\
\hline Basisonderwijs & 14,3 & hoog & 4.750 & 73 & zeer hoog \\
\hline VMBO Theorie & 14,2 & hoog & 2.600 & 52 & gemiddeld \\
\hline VMBO Techniek & 12,5 & hoog & 2.700 & 52 & gemiddeld \\
\hline VMBO Landbouw en natuurlijke omgeving & 9,8 & hoog & 175 & 43 & laag \\
\hline
\end{tabular}

Bron: Arbeidsvoorziening/ROA

Tabel 2.8 laat zien in welke opleidingssectoren het werkloosheidspercentage laag tot zeer laag is. Het betreft een zevental opleidingssectoren op middelbaar en hoger niveau die qua richting vrijwel de gehele arbeidsmarkt bestrijken. Er dient overigens opgemerkt te worden dat het percentage langdurig werkzoekenden voor de opleidingssectoren $\mathrm{HBO}$ onderwijs en

\section{Tabel 2.8}

Opleidingssectoren met een laag tot zeer laag aantal niet-werkende werkzoekenden als percentage van de beroepsbevolking in Limburg, april 1999

\begin{tabular}{|c|c|c|c|c|c|}
\hline \multirow{2}{*}{ Opleidingssector } & \multirow{2}{*}{$\begin{array}{c}\text { werkloosheid } \\
\%\end{array}$} & \multirow[t]{2}{*}{ typering } & \multicolumn{3}{|c|}{ langdurig werkzoekend typering } \\
\hline & & & aantal & $\%$ & \\
\hline HBO (Para)medisch & 0,2 & zeer laag & - & - & - \\
\hline HBO Economie & 0,6 & zeer laag & 25 & 43 & laag \\
\hline MBO Openbare orde en veiligheid & 0,7 & zeer laag & 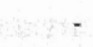 & -1 & $-2 \cot 2 \cos ^{2}$ \\
\hline HBO Techniek & 1,3 & zeer laag & 75 & 53 & gemiddeld \\
\hline MBO Landbouw en natuurlijke omgeving & 1,3 & zeer laag & 50 & 39 & zeer laag \\
\hline HBO Onderwijs en tolk en vertaler & 2,7 & laag & 200 & 61 & hoog \\
\hline HBO Sociaal-cultureel & 2,8 & laag & 75 & 60 & hoog \\
\hline
\end{tabular}

Bron: Arbeidsvoorziening/ROA 
tolk en vertaler en $\mathrm{HBO}$ sociaal-cultureel hoog is. Waarschijnlijk is bij deze opleidingen de werkloosheid tot een moeilijk inzetbare 'harde kern' teruggebracht.

\subsection{Discrepanties op de Limburgse arbeidsmarkt}

\section{Discrepantiemaatstaven en typering arbeidsmarktkrapte}

Uitgangspunt is het principe dat een vergelijking van het aantal openstaande vacatures en het aantal niet-werkende werkzoekenden de vraag-aanbodverhouding in een arbeidsmarktsegment weergeeft. Wanneer het aantal openstaande vacatures het aantal niet-werkende werkzoekenden overtreft is er sprake van een tekort. In het tegenovergestelde geval is er sprake van een overschot in het betreffende arbeidsmarktsegment. Omdat niet elke werkzoekende een gelijke geschiktheid heeft om een bepaalde vacature te vervullen, wordt een onderscheid gemaakt tussen direct bemiddelbare werkzoekenden en werkzoekenden met een grotere afstand tot de arbeidsmarkt ${ }^{16}$. Hierbij wordt gebruik gemaakt van het faseringsmodel van Arbeidsvoorziening. Bij deze indeling worden vier fasen onderscheiden. Nietwerkende werkzoekenden in fase 1 zijn onmiddellijk bemiddelbaar voor de arbeidsmarkt. Niet-werkende werkzoekenden in fase 2 en 3 hebben respectievelijk een kort of een langer scholings- of begeleidingsprogramma nodig om hun arbeidsmarktkansen te vergroten. Niet-werkende werkzoekenden in fase 4 kunnen daarentegen (voorlopig) niet naar de reguliere vacaturemarkt begeleid worden. Aangezien werkgevers primair geïnteresseerd zijn in mensen die direct inzetbaar zijn, wordt de arbeidsmarktkrapte op een bepaald arbeidsmarktsegment gedefinieerd als de verhouding tussen het aantal openstaande vacatures en het aantal niet-werkende werkzoekenden in fase 1.

Wanneer er sprake is van een tekort aan direct inzetbare werkzoekenden, zullen de vacatures ook opgevuld moeten worden door werkzoekenden die een grotere afstand tot de arbeidsmarkt hebben ${ }^{17}$. De knelpuntsindicator geeft aan in hoeverre er voldoende nietwerkende werkzoekenden in fase 2 en 3 beschikbaar zijn om de resterende openstaande vacatures na het volgen van een bijscholingstraject te kunnen vervullen.

Er bestaat overigens wel een aantal verschillen tussen de analyses op basis van vacaturecijfers enerzijds en de confrontatie van vraag en aanbod anderzijds. Deze verschillen kunnen diverse oorzaken hebben. Ten eerste belichten beide analyses een verschillend aspect van het probleem. Het percentage langdurig openstaande vacatures geeft bijvoorbeeld ook een indicatie van de wijze waarop werkgevers rekruteringsproblemen proberen te verhelpen. Wanneer het probleem tijdelijk intern wordt opgelost door bijvoorbeeld overwerk, zal de vacature blijven openstaan. Wanneer daarentegen gekozen wordt voor bijvoorbeeld het in dienst nemen van uitzendkrachten of werkzoekenden met een iets grotere afstand tot de arbeidsmarkt komen de rekruteringsproblemen niet tot uiting in een hoog percentage langdurig openstaande vacatures.

16 J. Hartog, Tussen vraag en aanbod, Stenfert Kroese, Leiden, 1980.

17 Daarbij wordt op dit moment voorbijgegaan aan de mogelijkheid deze vacatures op te vullen door het stimuleren van de participatie of (internationale) pendel. Hierop zal in de paragrafen 6.2 en 6.3 nader worden ingegaan. 
Een tweede oorzaak kan gelegen zijn in de eisen die vraag en aanbod stellen. Ondanks het feit dat er voldoende werkzoekenden zijn die geacht worden direct inzetbaar te zijn, kunnen werkgevers op sommige arbeidsmarktsegmenten toch problemen hebben met het vinden van geschikte mensen, hetzij omdat deze werkzoekenden om één of andere reden toch niet aan hun wensen voldoen, hetzij omdat de banen niet aan de wensen van de werkzoekenden voldoen. Hierbij kan gedacht worden aan andere aspecten dan de inhoudelijke aansluiting tussen kwalificaties waarover de werkzoekenden beschikken en de gevraagde kwalificaties, waarop in dit rapport de nadruk ligt. Voorbeelden zijn leeftijd, de duur van het arbeidscontract, werktijden, duur van de werkweek, etc.

Een derde oorzaak zou gelegen kunnen zijn in de heterogeniteit van de beroepssegmenten. De problemen kunnen zich in een zeer specifiek deelgebied binnen beroepssegmenten voordoen. Deze problemen leiden tot een hoog percentage langdurig openstaande vacatures, maar komen niet tot uiting in de arbeidsmarktkrapte. Daarnaast dient gewezen te worden op de aantrekkingskracht van het werken bij grotere bedrijven, waardoor bij knelpunten op de arbeidsmarkt vooral kleine bedrijven meer moeite hebben met het vinden van geschikt personeel. Bovendien kunnen grotere bedrijven rekruteringsproblemen beter opvangen door gebruik te maken van hun interne arbeidsmarkt.

\section{Arbeidsmarktkrapte naar bedrijfssector}

Tabel 2.9 geeft een overzicht van de arbeidsmarktkrapte naar bedrijfssector in Limburg in april 1999. De krapte blijkt het kleinst te zijn in de sector landbouw en visserij. Omdat de indicator voor de arbeidsmarktkrapte in deze sector kleiner is dan 1 , is hier zelfs sprake van

Tabel 2.9

Arbeidsmarktkrapte naar bedrijfssector in Limburg, april 1999

\begin{tabular}{lcc} 
Bedrijfssector & arbeidsmarktkrapte & typering \\
\cline { 2 - 3 } Landbouw en visserij & 0,80 & laag \\
Voeding & 1,47 & hoog \\
Chemie & 1,60 & hoog \\
Energie & 1,62 & hoog \\
Bank- en verzekeringswezen & 1,66 & hoog \\
Overheid en onderwijs & 1,70 & hoog \\
Overige industrie & 1,78 & hoog \\
Metaal en elektrotechniek & 1,81 & hoog \\
Bouw en onroerend goed & 1,91 & hoog \\
Transport en communicatie & 2,20 & zeer hoog \\
Horeca, reparatie en zak. dienstverlening & 2,30 & zeer hoog \\
Kwartaire diensten & 2,60 & zeer hoog \\
Handel & 2,84 & zeer hoog \\
& &
\end{tabular}

Bron: Arbeidsvoorziening/CBS/ROA 
een ruime arbeidsmarkt. Het feit dat de sector landbouw en visserij als geheel geen of weinig rekruteringsproblemen kent, betekent overigens niet dat zich in deze sector op zeer specifieke segmenten geen knelpunten kunnen voordoen. De geaggregeerde cijfers voor bedrijfssectoren geven nu eenmaal minder gedetailleerde informatie. In alle andere bedrijfssectoren is er duidelijk sprake van een krappe arbeidsmarkt. De krapte is het grootst in de dienstensectoren. In de sector handel zijn er per 100 niet-werkende werkzoekenden in fase 1 maar liefst 284 openstaande vacatures beschikbaar. Met zulke grote verschillen is het maar zeer de vraag of er voldoende werkzoekenden met een grotere afstand tot de arbeidsmarkt zijn om in deze behoefte te voorzien.

\section{Arbeidsmarktkrapte naar beroepssegment}

Tabel 2.10 geeft een beeld van de arbeidsmarktkrapte verbijzonderd naar beroepssegment. De tabel laat zien dat er in alle onderscheiden beroepssegmenten sprake is van een krappe arbeidsmarkt: de arbeidsmarktkrapte is groter dan 1. De arbeidsmarktkrapte is het grootst in de hogere (para)medische beroepen en de lagere beveiligingsberoepen. Een zestal beroepssegmenten wordt geconfronteerd met een grote tot zeer grote krapte. Het gaat daarbij om sterk uiteenlopende segmenten van de arbeidsmarkt. Het niveau van deze beroepen is overigens over het algemeen relatief laag. Voor het beroepssegment lagere verzorgende beroe-

Tabel 2.10

Arbeidsmarktkrapte en karakter van het tekort naar beroepssegment in Limburg, april 1999

\begin{tabular}{|c|c|c|c|c|}
\hline Beroepssegment & $\begin{array}{l}\text { arbeidsmarkt- } \\
\text { krapte }\end{array}$ & typering & $\begin{array}{l}\text { knelpunts- } \\
\text { indicator }\end{array}$ & $\begin{array}{l}\text { karakter van } \\
\text { het tekort }\end{array}$ \\
\hline Middelbare agrarische beroepen & 1,06 & hoog & 0,04 & kwalitatief \\
\hline Middelbare transportberoepen & 1,10 & hoog & 0,08 & kwalitatief \\
\hline Elementaire beroepen & 1,38 & hoog & 0,12 & kwalitatief \\
\hline Hogere pedagogische beroepen & 1,46 & hoog & 0,36 & kwalitatief \\
\hline Lagere technische beroepen & 1,61 & hoog & 0,57 & kwalitatief \\
\hline Lagere transportberoepen & 1,63 & hoog & 0,30 & kwalitatief \\
\hline Middelbare adm., comm., ec. beroepen & 1,66 & hoog & 0,27 & kwalitatief \\
\hline Middelbare verzorgende beroepen & 1,73 & hoog & 0,33 & kwalitaitef \\
\hline Hogere taalkundige, culturele beroepen & 1,79 & hoog & 0,20 & kwalitatief \\
\hline Middelbare beroepen m.b.t. gedrag en maatsch. & 2,44 & zeer hoog & 0,70 & kwalitaitef \\
\hline Middelbare taalkundige, culturele beroepen & 2,50 & zeer hoog & 0,75 & kwalitatief \\
\hline Middelbare (para)medische beroepen & 2,53 & zeer hoog & 0,53 & kwalitatief \\
\hline Lagere (para)medische beroepen & 2,54 & zeer hoog & 0,45 & kwalitatief \\
\hline Middelbare technische beroepen & 2,57 & zeer hoog & 0,91 & kwalitatief \\
\hline Lagere verzorgende beroepen & 3,48 & zeer hoog & 1,08 & kwantitatief \\
\hline Lagere adm., comm., ec. beroepen & 3,89 & zeer hoog & 1,12 & kwantitatief \\
\hline Lagere agrarische beroepen & 4,26 & zeer hoog & 1,46 & kwantitatief \\
\hline Lagere beveiligingsberoepen & 5,39 & zeer hoog & 1,36 & kwantitatief \\
\hline Hogere (para)medische beroepen & 8,33 & zeer hoog & 5,79 & kwantitatief \\
\hline
\end{tabular}

Bron: Arbeidsvoorziening/CBS/ROA 
pen wordt de krapte vooral veroorzaakt door vraagfactoren, i.c. een zeer hoge vacaturegraad. Voor de hogere (para)medische beroepen is daarentegen het aanbod van niet-werkende werkzoekenden zeer laag. Voor de lagere agrarische beroepen geldt dat zowel het aantal nietwerkende werkzoekenden als het percentage niet-werkende werkzoekenden in fase 1 laag is. Voor de overige segmenten is een combinatie van vraag- en aanbodfactoren voor de grote krapte verantwoordelijk.

Een tekort aan direct inzetbare werkzoekenden kan verschillende oorzaken hebben. De discrepanties op de arbeidsmarkt kunnen kwantitatief of kwalitatief van aard zijn. In tabel 2.10 wordt eveneens aangegeven of het tekort voor een bepaald beroepssegment kwalitatief dan wel kwantitatief van aard is. Voor het merendeel van de beroepssegmenten is er sprake van een kwalitatief aansluitingsprobleem. Dat wil zeggen dat het tekort aan direct inzetbare werkzoekenden gepaard gaat met een relatief groot aantal werkzoekenden met een grotere afstand tot de arbeidsmarkt. In dergelijke situaties kunnen scholings- of begeleidingsprogramma's, gericht op het verkleinen van deze afstand, een effectief middel zijn om het tekort aan werkzoekenden te verminderen. Aangezien de knelpuntsindicator kleiner is dan één, zijn er voldoende werkzoekenden in fase 2 en 3 beschikbaar om het tekort te verhelpen. De tabel bevat een aantal beroepssegmenten op elementair en lager niveau, waar het kwalitatieve karakter van de aansluitingsproblematiek niet inhoudelijk van aard is. Het feit dat er een groot aantal werkzoekenden een grotere afstand tot de arbeidsmarkt heeft, wordt met name door bijvoorbeeld lichamelijke (bijvoorbeeld gedeeltelijke arbeidsongeschiktheid) of sociale factoren veroorzaakt.

Er is sprake van een kwantitatief tekort wanneer een bepaald beroepssegment niet alleen wordt gekenmerkt door een tekort aan direct inzetbare werkzoekenden, maar er tevens onvoldoende aanbod is van werkzoekenden met een wat grotere afstand tot de arbeidsmarkt. Deze problemen doen zich voor bij de lagere verzorgende beroepen, de lagere administratieve, commerciële en economische beroepen, de lagere agrarische beroepen, de lagere beveiligingsberoepen en de hogere (para)medische beroepen. Zo is er in het laatstgenoemde beroepssegment slechts één direct inzetbare niet-werkende werkzoekende beschikbaar per (afgerond) 8 openstaande vacatures. Dit betekent overigens wel dat scholingsprogramma's een bijzonder effectief middel zijn om de werkloosheid in deze beroepssegmenten te verminderen. Bij de hogere (para)medische beroepen zijn er bijvoorbeeld 6 openstaande vacatures beschikbaar voor elke niet-werkende werkzoekende in fase 2 en 3. Om het tekort aan arbeidskrachten in segmenten met een kwantitatief tekort aan te pakken, zijn bijscholingsprogramma's die gericht zijn op werkzoekenden op het desbetreffende arbeidsmarktsegment die zijn ingedeeld in fase 2 en 3 echter niet toereikend. Niet alle openstaande vacatures in deze beroepen kunnen door het bijscholen van mensen in fase 2 en 3 opgevuld worden. Werving op andere arbeidsmarktsegmenten is derhalve noodzakelijk om werkzoekenden te vinden die via omscholing of 'substantiële bijscholing'l8 geschikt gemaakt kunnen worden voor beroepen met een kwantitatief tekort. In tabel 2.10 geldt dit in het bijzonder voor de hogere (para)medische beroepen waar de knelpuntsindicator beduidend groter is dan één.

18 Van substantiele scholing is bijvoorbeeld sprake wanneer iemand met een opleiding op VMBO-niveau word bijgeschoold tot op MBO-niveau. 


\section{Arbeidsmarktkrapte naar opleidingssector}

In tabel 2.11 wordt een overzicht gegeven van de arbeidsmarktkrapte voor de verschillende opleidingssectoren. Voor de opleidingssectoren VMBO Economie, Basisonderwijs, HAVO/ VWO, VMBO Theorie en VMBO Verzorging is er sprake van een ruime arbeidsmarkt. Het betreft hier opleidingen op een laag niveau en/of met een algemeen karakter. Kwalitatieve aansluitingsproblemen blijken vooral te bestaan bij de technische en verzorgende opleidingen op lager en middelbaar niveau. Voor de verplegende en verzorgende opleidingen bestaat het grote potentieel aan niet-werkende werkzoekenden met een min of meer grote afstand tot de arbeidsmarkt voornamelijk uit herintredende vrouwen. Deze groep werkzoekenden vindt doorgaans redelijk gemakkelijk zijn weg naar de arbeidsmarkt terug en kan dus op termijn een oplossing bieden voor het tekort aan direct inzetbare werkzoekenden.

Tabel 2.11

Arbeidsmarktkrapte en karakter van het tekort naar opleidingssector in Limburg, april 1999

Opleidingssector arbeidsmarkt- typering knelpunts- karakter van krapte indicator het tekort

\begin{tabular}{lllll}
\hline VMBO Economie & 0,15 & zeer laag & - & geen tekort \\
Basisonderwijs & 0,35 & zeer laag & - & geen tekort \\
HAVO/NWO & 0,52 & laag & - & geen tekort \\
VMBO Theorie & 0,68 & laag & - & geen tekort \\
VMBO Verzorging & 0,90 & laag & - & geen tekort \\
VMBO Landbouw en natuurlijke omgeving & 1,21 & hoog & 0,12 & kwalitatief \\
MBO Techniek & 1,48 & hoog & 0,29 & kwalitatief \\
VMBO Openbare orde en veiligheid & 2,08 & zeer hoog & 0,55 & kwalitatief \\
VMBO Techniek & 2,15 & zeer hoog & 0,59 & kwalitatief \\
MBO Dienstverlening en gezondheidszorg & 2,33 & zeer hoog & 0,52 & kwalitatief \\
MBO Economie & 3,38 & zeer hoog & 1,31 & kwantitatief \\
MBO Landbouw en natuurlijke omgeving & 3,38 & zeer hoog & 2,15 & kwantitatief \\
HBO Sociaal-cultureel & 4,17 & zeer hoog & 1,12 & kwantitatief \\
HBO Onderwijs en tolk en vertaler & 4,45 & zeer hoog & 1,58 & kwantitatief \\
HBO Techniek & 9,15 & zeer hoog & 4,91 & kwantitatief \\
HBO Economie & 10,00 & zeer hoog & 8,71 & kwantitatief \\
HBO Paramedisch & 12,50 & zeer hoog & 5,11 & kwantitatief
\end{tabular}

Bron: Arbeidsvoorziening/CBS/ROA

Over het algemeen worden de middelbare en hogere opleidingen gekenmerkt door een kwantitatief tekort. Zo is er slechts één direct bemiddelbare niet-werkende werkzoekende met een opleiding HBO Paramedisch beschikbaar per (afgerond) 13 openstaande vacatures. Soortgelijke problemen doen zich vaor bij de opleidingen HBO Economie en HBO Technick. Doorgaans zijn scholingsprogramma's een bijzonder effectief middel om de werkloosheid onder mensen met een opleidingsachtergrond waarvoor een kwantitatief tekort bestaat, te verminderen. Wanneer deze tekorten zich echter voornamelijk voordoen bij opleidingen op 
hoger niveau, dan zijn de mogelijkheden hiervoor relatief gering omdat de werkloosheid meestal ook laag is. Zo zijn er voor HBO Paramedisch voor elke niet-werkende werkzoekende in fase 2 en 3 weliswaar 5 openstaande vacatures beschikbaar, maar om het tekort aan arbeidskrachten in deze sector aan te pakken zijn bijscholingsprogramma's gericht op deze werkzoekenden niet toereikend. Werving op andere arbeidsmarktsegmenten is noodzakelijk om werkzoekenden te vinden die door omscholing geschikt gemaakt kunnen worden voor functies in deze sector.

\subsection{De actuele arbeidsmarktpositie van schoolverlaters}

In deze paragraaf zal een beeld worden geschetst van de actuele arbeidsmarktpositie van schoolverlaters. We beperken ons hierbij tot schoolverlaters van de BeroepsOpleidende Leerweg (BOL) in het secundair beroepsonderwijs (MBO) van de regionale opleidingscentra in Limburg: Arcus College, Gilde Opleidingen, Leeuwenborgh Opleidingen en het AOC. Het MBO wordt hiertoe in een viertal sectoren ingedeeld: $M B O$ Landbouw en natuurlijke omgeving, MBO Techniek, MBO Dienstverlening en gezondheidszorg en MBO Economie. Voor deze vier opleidingssectoren zal aan de hand van een aantal arbeidsmarktkenmerken de actuele positie van schoolverlaters op de arbeidsmarkt worden gekarakteriseerd.

Aansluitingsproblemen op de arbeidsmarkt kunnen zich op verschillende manieren manifesteren. Deze paragraaf richt zich allereerst op de (intrede-)werkloosheid onder schoolverlaters van het $\mathrm{MBO}$. Het werkloosheidspercentage voor een bepaalde opleidingssector geeft een indicatie van de 'open discrepanties' tussen vraag en aanbod. Naast deze open discrepanties kan er ook sprake zijn van 'verborgen discrepanties' bij diegenen die wel emplooi hebben gevonden. Daarvan is bijvoorbeeld sprake als schoolverlaters werk moeten accepteren beneden hun niveau of buiten hun vakgebied, slechter beloond worden, vaker een tijdelijke in plaats van een vaste aanstelling krijgen, of vaker genoegen moeten nemen met deeltijdwerk, terwijl men liever een full-timè betrekking zou willen hebben.

\section{Werkloosheid}

Een belangrijk aspect van de arbeidsmarktpositie van schoolverlaters is vanzelfsprekend de kans op het vinden van een baan. Tabel 2.12 geeft voor vier MBO-opleidingssectoren het werkloosheidspercentage onder schoolverlaters in 1998 weer. Daarbij worden de werkloosheidspercentages voor Limburg vergeleken met de gemiddelde werkloosheid onder schoolverlaters met de desbetreffende opleidingsachtergrond in Nederland.

De werkloosheid is het hoogst onder schoolverlaters van de opleidingssector $M B O$ Landbouw en natuurlijke omgeving. De werkloosheid is voor deze opleidingssector in Limburg ook veel hoger dan in de rest van Nederland. Dit hoge werkloosheidspercentage in Limburg wordt met name veroorzaakt door de relatief hoge werkloosheid onder schoolverlaters van het opleidingstype $M B O$ milieu en groene ruimte. Het werkloosheidspercentage voor MBO Techniek geeft daarentegen in Limburg een gunstiger beeld te zien dan landelijk. De zeer lage werkloosheid onder de technisch opgeleide MBO'ers in Limburg wijst op de grote krapte op deze segmenten van de Limburgse arbeidsmarkt. Opleidingstypen met een laag werkloosheidspercentage zijn $M B O$ werktuigbouw en mechanische techniek, MBO procestechniek en MBO motorvoertuigentechniek. Deze opleidingstypen profiteren van de nadruk- 
kelijke aanwezigheid van de industrie in Limburg. Daarnaast is de werkloosheid erg laag voor de opleidingen $M B O$ verpleging en $M B O$ dokters-, tandarts- en dierenartsassistent.

De werkloosheidspercentages per MBO-opleidingssector in 1998 zijn, voor zowel Nederland als Limburg, vergelijkbaar met de cijfers van 1997. De werkloosheidscijfers zijn in de meeste gevallen gelijk aan of iets lager dan de percentages van vorig jaar. MBO Dienstverlening en gezondheidszorg geeft in Limburg een kleine stijging in het werkloosheidspercentage te zien, van $2 \%$ in 1997 naar 3\% in 1998. Het werkloosheidspercentage voor de schoolverlaters van $M B O$ Economie is in Nederland in één jaar tijd gehalveerd van $6 \%$ in 1997 tot 3\% in 1998. In Limburg is deze daling voor MBO Economie minder uitgesproken, maar ook hier is er duidelijk sprake van een verhoogde kans op werk voor schoolverlaters van deze $\mathrm{MBO}$-opleidingssector.

Tabel 2.12

Werkloosheidspercentage onder schoolverlaters per MBO-opleidingssector, Limburg en Nederland, 1998

MBO-opleidingssector

$\begin{array}{cccc}\text { Limburg } & \text { typering } & \text { Nederland } & \text { typering } \\ \% & \% & \end{array}$

\begin{tabular}{lllll} 
MBO Landbouw en natuurlijke omgeving & 7 & hoog & 3 & gemiddeld \\
MBO Techniek & 1 & laag & 3 & gemiddeld \\
MBO Dienstverlening en gezondheidszorg & 3 & gemiddeld & 4 & gemiddeld \\
MBO Economie & 4 & gemiddeld & 3 & gemiddeld \\
MBO Totaal & 3 & - & 3 & - \\
\hline
\end{tabular}

Bron: $R O A$

Tabel 2.13 geeft een overzicht van de percentages gediplomeerde schoolverlaters van de verschillende opleidingssectoren met een intredewerkloosheid van vier maanden of meer. Het percentage schoolverlaters dat na het behalen van het diploma langer dan vier maanden werkloos is, is in Limburg hoger dan landelijk. Dit geldt voor alle vier opleidingssectoren. Hoewel het werkloosheidspercentage, zoals tabel 2.12 liet zien, vrij laag is en het merendeel van de schoolverlaters dus na enige tijd werk vind, betekent dit niet dat alle schoolverlaters al direct na het verlaten van de schoolbanken een baan hebben.

MBO-opleidingstypen die in Limburg met name te kampen hebben met een hoge intredewerkloosheid zijn MBO sociaal-cultureel, MBO administratie, MBO laboratorium en $M B O$ elektrotechniek. Schoolverlaters van de MBO-opleidingstypen MBO motorvoertuigen-techniek, MBO dokters-, tandarts- en dierenartsassistent, MBO werktuigbouw en mechanische techniek en $M B O$ secretariaat vinden daarentegen betrekkelijk snel een baan na afronding van hun opleiding.

In hoeverre komen de percentages uit tabel 2.13 overeen met de cijfers van vorig jaar? Met uitzondering van MBO Technick geldt dat voor alle MBO-opleidingssectoreu de intrede- 
werkloosheid in Limburg, evenals in de rest van Nederland, is afgenomen. Het percentage schoolverlaters dat langer dan 4 maanden op de eerste baan moet wachten is in de meeste gevallen zelfs sterk gedaald. MBO Economie, welke ook al een forse afname van het werkloosheidspercentage te zien had gegeven, spant ook nu de kroon: van 13\% in 1997 naar 5\% in 1998.

\section{Tabel 2.13}

Percentage schoolverlaters met een intredewerkloosheid langer dan 4 mnd. per MBOopleidingssector, Limburg en Nederland, 1998

\begin{tabular}{|c|c|c|c|c|}
\hline MBO-opleidingssector & $\begin{array}{c}\text { Limburg } \\
\%\end{array}$ & typering & Nederland & $\begin{array}{l}\text { typering } \\
\%\end{array}$ \\
\hline MBO Landbouw en natuurlijke omgeving & 7 & gemiddeld & 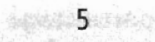 & gemiddeld \\
\hline MBO Techniek & 5 & gemiddeld & 3 & laag \\
\hline MBO Dienstverlening en gezondheidszorg & 6 & gemiddeld & 5 & gemiddeld \\
\hline MBO Economie & 7 & gemiddeld & 5 & gemiddeld \\
\hline MBO Totaal & 6 & - & 4 & - \\
\hline
\end{tabular}

Bron: ROA

\section{Beloning}

De beloning is ook een indicator voor de schaarste aan (nieuwe) werknemers met een bepaalde opleidingsachtergrond. Tabel 2.14 geeft voor de vier MBO-opleidingssectoren een overzicht van het gemiddelde bruto maandloon in 1998. Uit de tabel blijkt dat schoolverlaters van $M B O$ Techniek en $M B O$ Economie in Limburg gemiddeld genomen meer verdienen dan landelijk. Bij MBO Techniek hangt dit samen met de relatief grotere schaarste aan schoolverlaters in Limburg, zoals naar voren kwam uit het zeer lage werkloosheidspercentage. Voor MBO Economie is het verschil in bruto maandsalaris tussen de Limburgse schoolverlaters en de schoolverlaters in de rest van Nederland echter het grootst. De schoolverlaters van MBO Landbouw en natuurlijke omgeving verdienen daarentegen in Limburg gemiddeld genomen evenveel of minder dan landelijk.

Als we kijken naar de beloning per opleidingstype, dan komen in Limburg vooral MBO bouw, MBO procestechniek en MBO administratie erg gunstig naar voren. Schoolverlaters van deze opleidingstypen verdienen bruto rond 500 gulden meer in Limburg dan landelijk. MBO beweging en therapie is daarentegen een voorbeeld van een opleidingstype dat in Limburg minder verdient dan landelijk. 
Tabel 2.14

Gemiddelde bruto maandloon in guldens voor werkende schoolverlaters per opleidingstype, Limburg en Nederland, 1998

\begin{tabular}{llllll} 
MBO-opleidingssector & Limburg & typering & Nederland & typering \\
\cline { 5 - 6 } & & & & & \\
MBO Landbouw en natuurlijke omgeving & & laag & 2.450 & gemiddeld \\
MBO Techniek & 2.850 & gemiddeld & 2.600 & gemiddeld \\
MBO Dienstverlening en gezondheidszorg & 2.700 & gemiddeld & 2.700 & gemiddeld \\
MBO Economie & 2.750 & gemiddeld & 2.400 & laag \\
MBO Totaal & & & & 2.550 & -
\end{tabular}

Bron: ROA

Voor alle vier opleidingssectoren geldt dat het gemiddelde bruto maandloon in 1998 is gestegen ten opzichte van 1997. In sommige gevallen is de stijging fors te noemen. De beloning van Limburgse schoolverlaters van de opleidingssector $M B O$ Economie is maar liefst met meer dan $25 \%$ gestegen. Ook bij de andere opleidingssectoren is er sprake van een aanzienlijke stijging van de lonen.

\section{Aard van het dienstverband}

De aard van het dienstverband van schoolverlaters hangt doorgaans ook samen met hun arbeidsmarktpositie. Bij een verkrapping van de arbeidsmarkt zullen werkgevers vaker proberen hun werknemers zoveel mogelijk aan zich te binden. Verkrapping van de arbeidsmarkt remt daardoor de flexibilisering van de arbeidsmarkt af. Tabel 2.15 laat zien dat de schoolverlaters van MBO Techniek het minst vaak een flexibele aanstelling hebben. We spreken hier van een flexibele aanstelling als er sprake is van een tijdelijk arbeidscontract (zoals bij uitzendkrachten, oproepkrachten en invalskrachten) en contracten zonder 'een vast aantal arbeidsuren. Hierbij wordt een contract als niet-vast aangemerkt wanneer de contractuele termijn korter is dan een jaar en er geen vooruitzicht is op een vast dienstverband. Bij MBO procestechniek heeft slechts 19\% van de schoolverlaters een flexibele aanstelling. Ook de schoolverlaters van MBO motorvoertuigentechniek en MBO elektrotechniek hebben lage flex-werk percentages in Limburg.

MBO Dienstverlening en gezondheidszorg is daarentegen een opleidingssector waarin zowel opleidingstypen met hoge, als opleidingstypen met lage percentages flex-werkers voorkomen. Zo zijn er onder schoolverlaters van de opleidingstypen $M B O$ uiterlijke verzorging, MBO apothekersassistent en MBO dokters-, tandarts- en dierenartsassistent zeer weinig flexwerkers. Daarentegen hebben $M B O$ sociaal-cultureel en $M B O$ verzorging juist veel tot zeer veel flex-werkers onder hun schoolverlaters. Andere opleidingstypen met relatief veel flexibele aanstellingen in Limburg zijn MBO administratie en MBO secretariaat. Voor de meeste opleidingstypen geldt dat er slechts geringe verschillen bestaan tussen de percentages flexwerkers in Limburg en in de rest van Nederland. 
Het percentage flexibele aanstellingen onder de schoolverlaters is tussen 1997 en 1998 voor alle MBO-opleidingssectoren gedaald, behalve voor MBO Techniek. Bij alle andere opleidingstypen is er dus een relatieve toename van het aantal vaste aanstellingen. Dit wijst eveneens op de toegenomen krapte op de arbeidsmarkt. Opmerkelijk genoeg is dit dus niet het geval bij MBO Techniek. Werkgevers voelen zich, ondanks de grote krapte op de arbeidsmarkt, kennelijk niet geroepen technisch opgeleide schoolverlaters een vast contract aan te bieden.

Tabel 2.15

Percentage werkende schoolverlaters met een flexibele aanstelling per MBO-opleidingssector, Limburg en Nederland, 1998

\begin{tabular}{|c|c|c|c|c|}
\hline MBO-opleidingssector & $\begin{array}{c}\text { Limburg } \\
\%\end{array}$ & typering & Nederland & $\begin{array}{l}\text { typering } \\
\%\end{array}$ \\
\hline MBO Landbouw en natuurlijke omgeving & 37 & gemiddeld & 32 & gemiddeld \\
\hline MBO Techniek & 30 & laag & 33 & gemiddeld \\
\hline MBO Dienstverlening en gezondheidszorg & 38 & gemiddeld & 35 & gemiddeld \\
\hline MBO Economie & 44 & gemiddeld & 38 & gemiddeld \\
\hline MBO Totaal & 38 & - & 35 & - \\
\hline
\end{tabular}

Bron: $R O A$

Tabel 2.16 toont een tweede aspect van de flexibilisering, namelijk de mate waarin er in deeltijd wordt gewerkt. Het hoge percentage deeltijders bij MBO Dienstverlening en gezondheidszorg is met name toe te schrijven aan de opleidingstypen $M B O$ verpleging, $M B O$ verzorging, $M B O$ uiterlijke verzorging en $M B O$ sociaal-cultureel. Het hoge percentage deeltijders bij deze opleidingen hangt samen met het hoge percentage vrouwen onder de schoolverlaters. De opleidingssector MBO Techniek, een sector met een zeer laag percentage vrouwen, heeft daarentegen een zeer laag percentage deeltijdwerkers. De opleidingstypen MBO werktuigbouw en mechanische techniek en MBO motorvoertuigentechniek kennen het laagste percentage deeltijdwerkers.

De mate waarin in deeltijd wordt gewerkt hangt vanzelfsprekend ook samen met de wens van de schoolverlaters zelf om in deeltijd te werken. Veel in deeltijd werkende schoolverlaters zouden echter - wanneer de mogelijkheid bestond - liever voltijd werken. Van alle in deeltijd werkende schoolverlaters met een MBO-opleidingsachtergrond zou $54 \%$ liever fulltime aan de slag gaan. Deze wens komt in Limburg vooral veel voor bij het opleidingstype MBO horeca. Maar liefst $92 \%$ van de deeltijdwerkers onder de schoolverlaters van dit opleidingstype geeft aan onvrijwillig in deeltijd te werken. 
Tabel 2.16

Percentage werkende schoolverlaters dat in deeltijd werkt per MBO-opleidingssector, Limburg en Nederland, 1998

\begin{tabular}{|c|c|c|c|c|}
\hline MBO-opleidingssector & $\begin{array}{c}\text { Limburg } \\
\%\end{array}$ & typering & $\begin{array}{c}\text { Nederland } \\
\%\end{array}$ & typering \\
\hline MBO Landbouw en natuurlijke omgeving & 12 & gemiddeld & 21 & gemiddeld \\
\hline MBO Techniek & 8 & laag & 16 & gemiddeld \\
\hline MBO Dienstverlening en gezondheidszorg & 50 & hoog & 50 & hoog \\
\hline MBO Economie & 22 & gemiddeld & 17 & gemiddeld \\
\hline MBO Totaal & 29 & - & 26 & - \\
\hline
\end{tabular}

Bron: ROA

\section{Aansluiting tussen opleiding en werk}

De 'kwalitatieve' aansluiting tussen beroep en opleiding kent twee dimensies:

- de benutting van het verworven kwalificatieniveau;

- de aansluiting tussen de gevolgde opleidingsrichting en de inhoud van de baan.

Hoe kleiner het percentage schoolverlaters dat op een te laag functieniveau werkzaam is en hoe kleiner het percentage schoolverlaters dat buiten de gevolgde vakrichting werkzaam is, des te beter is de aansluiting tussen opleiding en baan.

Aangenomen mag worden dat een verkrapping op de arbeidsmarkt leidt tot een verbetering van de aansluiting tussen de gevolgde opleiding en de baan die men heeft. Men is dan immers niet gedwongen uit te wijken naar een baan op een lager niveau of in een ander beroepsveld ${ }^{19}$. De tabellen 2.17 en 2.18 geven de percentages schoolverlaters van de vier MBO-sectoren waarbij er sprake is van 'onderbenutting' (d.w.z. werken onder het eigen niveau) en werken buiten de eigen vakrichting.

Gezien de krapte op de arbeidsmarkt is het opmerkelijk hoeveel schoolverlaters nog aangeven op een, in vergelijking met hun opleidingsniveau, te laag functieniveau werkzaam te zijn. Voor het MBO als geheel zijn de Limburgse schoolverlaters, vergeleken mel de resı van Nederland, echter minder vaak op een te laag niveau werkzaam. De verschillen tussen Limburg en het landelijke beeld zijn op dit punt het grootst voor MBO Landbouw en natuurlijke omgeving en MBO Techniek. Dit doet vermoeden dat voor deze twee opleidingssectoren de aansluiting zussen opleiding en beroep in Limburg beter is dan landelijk het geval is. Bij MBO Techniek hang dit samen met de grotere schaarste aan schoolverlaters in Limburg. Op een meer gedetailleerd niveau valt in Limburg de hoge 'onderbenutting' op bij schoolverla-

19 Een verkrapping van de arbeidsmarkt kan overigens op een gegeven moment ook weer de aansluiting tussen opleiding en werk verslechteren, wanneer werkgevers gedwongen zijn schoolverlaters op een, in vergelijking tor hun opleiding, te hoog functieniveau in te zetten 
Tabel 2.17

Onderbenutting per MBO-opleidingssector, Limburg en Nederland, 1998

\begin{tabular}{|c|c|c|c|c|}
\hline MBO-opleidingssector & $\begin{array}{c}\text { Limburg } \\
\%\end{array}$ & typering & $\begin{array}{c}\text { Nederland } \\
\%\end{array}$ & typering \\
\hline MBO Landbouw en natuurlijke omgeving & 34 & gemiddeld & 41 & hoog \\
\hline MBO Techniek & 27 & gemiddeld & 46 & hoog \\
\hline MBO Dienstverlening en gezondheidszorg & 26 & gemiddeld & 28 & gemiddeld \\
\hline MBO Economie & 30 & gemiddeld & 33 & gemiddeld \\
\hline MBO Totaal & 28 & - & 36 & - \\
\hline
\end{tabular}

Bron: ROA

ters van $M B O$ verzorging, $M B O$ uiterlijke verzorging, $M B O$ handel en $M B O$ bedrijfskunde. Voor alle $\mathrm{MBO}$-opleidingssectoren wordt overigens de aansluiting tussen het niveau van de gevolgde opleiding en het functieniveau in Limburg in 1998 positiever beoordeeld dan in 1997.

Ook tabel 2.18 laat zien dat de Limburgse schoolverlaters minder vaak buiten hun eigen vakrichting werkzaam zijn dan in de rest van Nederland. Toch is het percentage schoolverlaters in Limburg dat buiten de eigen vakrichting werkzaam is relatief hoog. Dit kan overigens ook betekenen dat de schaarste op bepaalde arbeidsmarktsegmenten een aanzuigende werking heeft op schoolverlaters in andere vakrichtingen. Met name de opleidingstypen $M B O$ verzorging, $M B O$ handel en $M B O$ bedrijfskunde hebben in Limburg een hoog percentage schoolverlaters dat buiten de eigen vakrichting werkzaam is. De aansluiting van deze specifieke opleidingstypen laat dus duidelijk te wensen over. Dit weerspiegelt de minder gunstige arbeidsmarktpositie van schoolverlaters van deze opleidingen.

Tabel 2.18

Buiten vakrichting per MBO-opleidingssector, 1998

\begin{tabular}{|c|c|c|c|c|}
\hline MBO-opleidingssector & $\begin{array}{c}\text { Limburg } \\
\%\end{array}$ & typering & Nederland & $\begin{array}{l}\text { typering } \\
\%\end{array}$ \\
\hline MBO Landbouw en natuurlijke omgeving & 42 & hoog & 37 & gemiddeld \\
\hline MBO Techniek & 22 & gemiddeld & 36 & gemiddeld \\
\hline MBO Dienstverlening en gezondheidszorg & 28 & gemiddeld & 28 & gemiddeld \\
\hline MBO Economie & 38 & hoog & 48 & hoog \\
\hline MBO Totaal & 30 & - & 38 & - \\
\hline
\end{tabular}

Bron: ROA 
Een vergelijking met 1997 laat zien dat het percentage schoolverlaters dat buiten de eigen vakrichting werkzaam is, in Nederland voor alle opleidingssectoren is gestegen of gelijk is gebleven. In Limburg is MBO Dienstverlening en gezondheidszorg echter de enige MBOopleidingssector die het landelijke beeld volgt. De andere opleidingssectoren geven tussen 1997 en 1998 namelijk juist een afname te zien van het percentage schoolverlaters dat buiten de eigen vakrichting werkt. Deze daling voor MBO Landbouw en natuurlijke omgeving, $M B O$ Techniek en $M B O$ Economie staat dus haaks op de landelijke veranderingen. 


\section{De Limburgse arbeidsmarkt in $\mathbf{2 0 0 0}$}

De economische groei in Limburg zal, naar verwachting, in 2000 op een wat lager niveau komen te liggen vergeleken met de groei in de afgelopen jaren. De werkgelegenheid zal ondanks dat nog toenemen met ongeveer 0,7\%. Deze groei is goed voor ruim 3.000 banen. De economische groei is niet alleen verantwoordelijk voor de vraag naar nieuwe arbeidskrachten. Er ontstaan ook baanopeningen door de arbeidsmarktuitstroom van werkenden. We spreken hier respectievelijk van de uitbreidingsvraag en de vervangingsvraag. Hiervan geeft de uitbreidingsvraag een indicatie van de groei dan wel krimp van de werkgelegenheid voor een specifieke beroepsgroep en wordt de vervangingsvraag veroorzaakt door (vervroegde) pensionering, arbeidsongeschiktheid, tijdelijke terugtreding van de arbeidsmarkt, beroepsmobiliteit, e.d. De verwachting is dat de arbeidsmarktuitstroom in Limburg in 2000 even hoog is als in 1999, namelijk ongeveer 5\% van het aantal werkenden. Mede door de afname van de werkgelegenheidsgroei is de vervangingsvraag veruit de belangrijkste vraagcomponent op de Limburgse arbeidsmarkt.

Eén en ander levert, naar verwachting, in Limburg in 2000 ongeveer 25.000 baanopeningen op voor nieuwhomers op de arbeidsmarkt. Dit is, vooral vanwege de teruglopende werkgelegenheidsgroei, ongeveer 8.000 minder dan in 1999.

De arbeidsmarktinstroom van schoolverlaters geeft in Limburg in 2000 een stijging te zien ten opzichte van 1999. Naar verwachting zal er een aanbod van nieuwe schoolverlaters op de Limburgse arbeidsmarkt zijn ter grootte van ongeveer $4 \%$ van het aantal werkenden. Dit betekent in concreto dat er in 2000 ongeveer 19.000 schoolverlaters op de Limburgse arbeidsmarkt op zoek zullen gaan naar een baan. Het aanbod van schoolverlaters blijft daardoor sterk achter bij de vraag naar nieuwkomers. Hierdoor zullen in 2000 de reeds bestaande knelpunten op de arbeidsmarkt nog groter worden. Het tekort aan direct-inzetbare werkzoekenden en schoolverlaters ten opzichte van de baanopeningen en vacatures is met 9.300 personen aanzienlijk gestegen vergeleken met de verwachtingen voor 1999.

Het in kaart brengen van de beroepsgroepen waarvoor werkgevers in 2000 knelpunten in de personeelsvoorziening kunnen verwachten, levert een breed scala aan beroepen op. Het gaat hier zowel om technische beroepen als om verzorgende beroepen. Voor het oplossen van dit vraagoverschot moet gedacht worden aan het bij- of omscholen van werkzoekenden met een grotere afstand tot de arbeidsmarkt, het inzetten van buitenlandse werkzoekenden (zgn. internationale pendel) of het bevorderen van de participatie van de stille arbeidsreserve, zoals vrouwen en ouderen.

\subsection{Inleiding}

In dit hoofdstuk zal aandacht worden besteed aan de verwachte situatie op de Limburgse arbeidsmarkt in 2000, op basis van de verwachte arbeidsmarktontwikkelingen op korte termijn. Aan de hand van prognoses van de toekomstige vraag en het toekomstige aanbod van arbeidskrachten, zal een inventarisatie worden gemaakt van de toekomstige knelpunten in de personeelsvoorziening. Tevens zal worden aangegeven welke maatregelen vereisı zijn om deze discrepanties tussen vraag en aanbod te voorkomen. De prognoseresultaten bevorderen zo een tijdige identificatie van de verwachte probleemgebieden. De voorspel- 
lingen in dit hoofdstuk dienen hiermee dus een belangrijk beleidsdoel: werkgevers kunnen de geboden informatie gebruiken om in hun personeelsbeleid te anticiperen op verwachte knelpunten in de personeelsvoorziening.

Afgezien van aanpassingen in het wervings- en selectiebeleid, kunnen werkgevers vooruitlopend op de verwachte arbeidsmarktontwikkelingen ook veranderingen aanbrengen in het interne scholingsbeleid, het eventuele outplacementbeleid e.d. Voor organisaties die betrokken zijn bij scholingsbeleid, zoals Arbeidsvoorziening, de regionale opleidingscentra (ROC's) en het AOC-Limburg, kan de indicatie van de op korte termijn te verwachten knelpunten op de arbeidsmarkt als richtsnoer fungeren voor een marktconform scholingsbeleid dat gericht is op de reïntegratie van werklozen en andere niet-participerenden. Daarmee is het hier geschetste beeld ook een bruikbare leidraad voor degenen die op korte termijn op zoek zijn naar een baan teneinde hun kansen op de arbeidsmarkt goed te kunnen inschatten.

De verdere opbouw van dit hoofdstuk is als volgt. In paragraal 3.2 worden eerst de cijfers gepresenteerd voor de verwachte baanopeningen per beroepsgroep op de Limburgse arbeidsmarkt in 2000. Deze baanopeningen zijn opgebouwd uit twee afzonderlijke vraagcomponenten: de zogenaamde uitbreidingsvraag en de vervangingsvraag, welke in meer detail in de Statistische Bijlage bij dit rapport worden gepresenteerd. Tegenover deze verwachte vraag staat een toekomstig aanbod van nieuwe arbeidskrachten: de arbeidsmarktinstroom van schoolverlaters. Door het vergelijken van de verwachte vraag en het verwachte aanbod voor de verschillende beroepsgroepen kan een indicatie worden gegeven van de knelpunten in de personeelsvoorziening waarmee werkgevers naar verwachting in 2000 zullen worden geconfronteerd. In paragraaf 3.3 zullen enkele aspecten van het scholings- en onderwijsbeleid in Limburg aan bod komen. Hierbij zal nader worden ingegaan op het verwachte vraagoverschot op de Limburgse arbeidsmarkt en zal daarnaast een indicatie worden gegeven van de vereiste inspanningen in het kader van om- en bijscholingstrajecten, zoals deze gewenst zijn in anticipatie op de verwachte knelpunten. Paragraaf 3.4 geeft vervolgens een samenvattend overzicht van de aandachtspunten van het scholingsbeleid.

\subsection{Knelpunten op de Limburgse arbeidsmarkt in 2000}

Baanopeningen in een bepaalde beroepsgroep kunnen voortkomen uit uitbreidingsvraag en vervangingsvraag. De uitbreidingsvraag geeft een indicatie van de economische groei dan wel krimp van de werkgelegenheid voor een specifieke beroepsgroep. De vervangingsvraag word veroorzaakı door (vervroegde) pensionering, arbeidsongeschiktheid, tijdelijke terugtreding van de arbeidsmarkı, beroepsmobiliteit, e.d. Bij een toename van de werkgelegenheid vormen de uitbreidingsvraag en de vervangingsvraag tezamen het totale aantal baanopeningen voor nieuwkomers op de arbeidsmarkt. Bij krimpende werkgelegenheid is er alleen sprake van baanopeningen vanwege de vervangingsvraag.

In deze paragraaf presenteren we de verwachte baanopeningen op de Limburgse arbeidsmarkt in 2000, per beroepsgroep. Voor de onderliggende uitbreidingsvraag- en vervangingsvraagprognoses wordt verwezen naar respectievelijk tabel 3.2 en 3.3 van de Statistische Bijlage, waar deze uitkomsten in meer detail worden gepresenteerd. 
De toekomstige knelpunten in de personeelsvoorziening zijn het resultaat van ontwikkelingen aan zowel de vraag-als aanbodzijde van de arbeidsmarkt. Daarbij gaat het in essentie om een vergelijking van het aantal baanopeningen voor nieuwkomers op de arbeidsmarkı en de arbeidsmarktinstroom. Dit betekent dat er geen een één-op-én relatie bestaat tussen het aantal baanopeningen en de verwachte knelpunten op de arbeidsmarkt. Zo kan er bij een gering aantal baanopeningen toch sprake zijn van grote knelpunten in de personeelsvoorziening, wanneer er tegelijkertijd sprake is van een lage arbeidsmarktinstroom.

\section{Baanopeningen}

Tabel 3.1 toont de beroepsgroepen met het relatief grootste aantal verwachte baanopeningen, als percentage van de werkgelegenheid. De beroepsgroepen verkopers en receptionisten en administratieve employés voeren de lijst aan, met een verwacht aantal baanopeningen ter grootte van $10 \%$ van het huidige aantal werkenden. Men zou nu geneigd kunnen zijn beide beroepen over één kam te scheren, maar er zijn wel degelijk verschillen tussen deze twee beroepen als het gaat om de oorzaken van de hoge vraag. De grote vraag bij verkopers kom voornamelijk voort uit de erg hoge uitbreidingsvraag, waarschijnlijk mede als gevolg van de verruiming van de openingstijden van winkels. De grote vraag bij receptionisten en administratieve employés wordt daarentegen voornamelijk veroorzaakt door de erg hoge vervangingsvraag.

De verschillen tussen de in tabel 3.1 gepresenteerde beroepsgroepen en de beroepsgroepen waarvoor in het vorige RAIL-rapport in 1999 de grootste aantallen baanopeningen werden verwacht zijn opmerkelijk. Alleen de ziekenverzorgenden en de systeemanalisten waren ook in 1999 beroepsgroepen met een relatief groot aantal verwachte baanopeningen. Waarschijnlijk zijn de verschillen mede een gevolg van de verschuivingen in de opbouw

Tabel 3.1

Beroepsgroepen met het relatief grootste aantal verwachte baanopeningen (als percentage van de werkgelegenheid) in Limburg in 2000

\begin{tabular}{|c|c|c|c|c|}
\hline Beroepsgroep & $\begin{array}{c}\text { baanopeningen } \\
\%\end{array}$ & typering & $\begin{array}{l}\text { uitbreidings- } \\
\text { vraag }\end{array}$ & $\begin{array}{l}\text { vervangings- } \\
\text { vraag }\end{array}$ \\
\hline Verkopers & 10,4 & erg hoog & erg hoog ${ }^{\star}$ & gemiddeld \\
\hline Receptionisten en administratieve employés & 9,6 & erg hoog & hoog & erg hoog* \\
\hline Interieurverzorgers & 7,6 & hoog & erg hoog* & gemiddeld \\
\hline Productieplanners & 7,6 & hoog & erg hoog* & laag \\
\hline Systeemanalisten & 7,5 & hoog & erg hoog* & erg laag \\
\hline Ziekenverzorgenden & 6,9 & hoog & erg hoog* & laag \\
\hline Commercieel medewerkers & 6,4 & hoog & erg hoog* & laag \\
\hline Docenten talen en expressie & 6,4 & hoog & laag & erg hoog* \\
\hline Assistent accountants & 6,3 & hoog & hoog $^{*}$ & gemiddeld \\
\hline
\end{tabular}

* de belangrijkste oorzaak van het grote aantal verwachte baanopeningen

Bron: $R O A$ 
van de vraag. Tabel 3.1 laat zien dat in de meeste gevallen waar er sprake is van grote tot zeer grote aantallen verwachte baanopeningen, de uitbreidingsvraag nu de grootste bijdrage aan de vraag naar nieuwkomers levert. In De Limburgse arbeidsmarkt 1998-2002 kon het merendeel van de baanopeningen van de beroepsgroepen met de grootste vraag nog worden toegeschreven aan de vervangingsvraag.

Naast de beroepen met een relatieve grote verwachte vraag, zijn er natuurlijk ook beroepsgroepen welke weinig tot geen baanopeningen bieden voor nieuwkomers. Tabel 3.2 geeft een overzicht van de beroepsgroepen met het relatief kleinste aantal verwachte baanopeningen in Limburg in 2000, als percentage van het huidige aantal werkenden in de betreffende beroepsgroep. In de tabel komen met name hogere en middelbare beroepsgroepen voor. De twee lijstaanvoerders zijn juristen en programmeurs, elk met minder dan 3\% verwachte baanopeningen in Limburg. De meeste beroepen uit tabel 3.2 worden geconfronteerd met een krimp in de werkgelegenheid waardoor er alleen baanopeningen ontstaan door de vervangingsbehoefte.

Tabel 3.2

Beroepsgroepen met het relatief kleinste aantal verwachte baanopeningen (als percentage van de werkgelegenheid) in Limburg in 2000

\begin{tabular}{|c|c|c|c|c|}
\hline Beroepsgroep & $\begin{array}{c}\text { baanopeningen } \\
\%\end{array}$ & typering & $\begin{array}{l}\text { uitbreidings- } \\
\text { vraag }\end{array}$ & $\begin{array}{l}\text { vervangings- } \\
\text { vraag }\end{array}$ \\
\hline Juristen & 2,7 & laag & gemiddeld & laag \\
\hline Programmeurs & 2,8 & gemiddeld & gemiddeld & erg laag \\
\hline Medewerkers sociaal-cult. werk en & & & & \\
\hline personeel en arbeid & 3,1 & gemiddeld & laag & gemiddeld \\
\hline Commercieel employés & 3,1 & gemiddeld & gemiddeld & gemiddeld \\
\hline Boekhouders en secretaresses & 3,2 & gemiddeld & gemiddeld & laag \\
\hline Accountants & 3,3 & gemiddeld & gemiddeld & laag \\
\hline Asp. politieagenten, soldaten en & & & & \\
\hline beveiligingshulpkrachten & 3,3 & gemiddeld & laag & gemiddeld \\
\hline Assembleurs & 3,3 & gemiddeld & laag & gemiddeld \\
\hline Chauffeurs & 3,4 & gemiddeld & gemiddeld & gemiddeld \\
\hline Monteurs & 3,5 & gemiddeld & gemiddeld & gemiddeld \\
\hline
\end{tabular}

Bron: ROA

Opvallend is de aanwezigheid van de beroepsgroep boekhouders en secretaresses in tabel 3.2, omdat deze beroepsgroep in De Limburgse arbeidsmarkt 1998-2002 nog was ingedeeld bij de beroepen met een relatief groot aantal verwachte baanopeningen. Met name de terugval in de verwachte uitbreidingsvraag is de oorzaak van het geringe percentage baanopeningen in deze beroepsgroep. Het totale aantal verwachte baanopeningen is voor boekhouders en secretaresses nog steeds ongeveer 1.000. Gezien het grote aantal werkenden in deze beroepsgroep is dit echter verhoudingsgewijs gering. 


\section{Toekomstige knelpunten in de personeelsvoorziening}

Om een indicatie te krijgen van de verwachte knelpunten in de personeelsvoorziening moeten de baanopeningen in de verschillende beroepsgroepen worden afgezet tegen het verwachte aanbod van nieuwkomers op de arbeidsmarkt. Daarbij is alleen gekeken naar de beroepen en opleidingen op middelbaar niveau of lager, gezien het meer landelijke karakter van de arbeidsmarkt voor de hogere beroepen of opleidingen. In de Statistische Bijlage wordt een gedetailleerd overzicht gegeven van de verwachte instroom van schoolverlaters, verbijzonderd naar beroepsgroep en opleidingstype.

Tabel 3.3 geeft een overzicht van de beroepsgroepen, op middelbaar niveau of lager, waarvoor de knelpunten in de personeelsvoorziening naar verwachting in 2000 in Limburg relatief groot zullen zijn. Om aan te geven waardoor deze knelpunten voornamelijk worden veroorzaakt, zijn tevens de typeringen van het verwachte aantal baanopeningen en de verwachte arbeidsmarktinstroom van schoolverlaters in de tabel opgenomen. Sommige beroepen die we hier zien, kwamen ook voor in tabel 3.1, maar niet in alle gevallen leidı een groot aantal verwachte baanopeningen tot grote knelpunten. De omvang van de verwachte instroom aan schoolverlaters is evenzeer van belang. We zien in de tabel dat in de meeste gevallen de beroepsgroepen met veel baanopeningen tevens een hoge arbeidsmarktinstroom van schoolverlaters hebben. Hoewel de instroom van nieuwe arbeidskrachten vanuit de opleidingen niet toereikend is om alle baanopeningen te vullen, biedt ze dus

Tabel 3.3

Beroepsgroepen waarvoor in 2000 in Limburg grote knelpunten in de personeelsvoorziening worden verwacht

\begin{tabular}{|c|c|c|c|c|}
\hline Beroepsgroep & ITKB & knelpunten & $\begin{array}{l}\text { baan- } \\
\text { openingen }\end{array}$ & $\begin{array}{l}\text { arbeidsmarkt } \\
\text { instroom }\end{array}$ \\
\hline Assembleurs & 0,90 & groot & gemiddeld & laag \\
\hline Verkopers & 0,90 & groot & erg hoog & hoog \\
\hline Receptionisten en administratieve employés & 0,92 & groot & erg hoog & hoog \\
\hline Hulpkrachten horeca en verzorging & 0,92 & groot & gemiddeld & hoog \\
\hline Interieurverzorgers & 0,93 & groot & hoog & hoog \\
\hline Procesoperators & 0,95 & groot & erg laag & erg laag \\
\hline Productieplanners & 0,95 & groot & hoog & erg hoog \\
\hline Aannemers en installateurs & 0,96 & groot & gemiddeld & hoog \\
\hline Bankwerkers en lassers & 0,96 & groot & gemiddeld & gemiddeld \\
\hline Weg-en waterbouwkundige vakkrachten & 0,97 & groot & hoog & gemiddeld \\
\hline Kantoorhulpen, inpakkers en colporteurs & 0,97 & groot & hoog & hoog \\
\hline Ziekenverzorgenden & 0,97 & groot & hoog & hoog \\
\hline Verzorgend personeel & 0,97 & groot & gemiddeld & hoog \\
\hline \multicolumn{5}{|l|}{ Asp. politieagenten, soldaten en } \\
\hline beveiligingshulpkrachten & 0,97 & groot & gemiddeld & erg hoog \\
\hline
\end{tabular}

Bron: $R O A$ 
toch de nodige verlichting van de knelpunten in de personeelsvoorziening. De grote diversiteit van beroepen in de tabel geeft eens te meer aan dat knelpunten in de personeelsvoorziening in 2000 naar verwachting over de volle breedte van de Limburgse arbeidsmarkt zullen optreden.

Voor het vaststellen van de verwachte knelpunten in de personeelsvoorziening naar beroep gebruiken we de Indicator Toekomstige Knelpunten in de personeelsvoorziening naar Beroep (ITKB). Deze indicator geeft aan in welke mate werkgevers problemen ondervinden bij het aantrekken van geschikt personeel. Naarmate de waarde van de ITKB lager is, zijn er meer knelpunten te verwachten. Wanneer het aanbod kleiner is dan de vraag, dan is de ITKB kleiner dan 1,00. De knelpunten in de personeelsvoorziening worden dan als groot getypeerd. Als de waarde van de indicator zelfs kleiner is dan 0,85 wordt gesproken van zeer grote knelpunten. Wanneer de ITKB daarentegen tussen 1,00 en 1,05 ligt, dan wordt gesproken van enige knelpunten. Bij een hogere waarde van de ITKB is sprake van vrijwel geen knelpunten, en indien de ITKB zelfs groter is dan 1,15, dan zijn er geen knelpunten in de personeelsvoorziening.

Tabel 3.4 geeft een overzicht van de beroepsgroepen waarvoor de knelpunten in de personeelsvoorziening in 2000 naar verwachting relatief gering zullen zijn. Verwacht wordt dat in het jaar 2000 het aantal beroepsgroepen waarvoor er slechts geringe knelpunten in de personeelsvoorziening zijn, groter is dan in 1999. De tabel suggereert dat dit vooral komt door de hoge(re) instroom van schoolverlaters. Tevens geldt dat er geen enkele beroepsgroep op de Limburgse arbeidsmarkt voorkomt waarvoor vrijwel geen knelpunten worden verwacht.

Tabel 3.4

Beroepsgroepen waarvoor in 2000 in Limburg enige knelpunten in de personeelsvoorziening worden verwacht

\begin{tabular}{|c|c|c|c|c|}
\hline Beroepsgroep & ITKB & knelpunten & $\begin{array}{l}\text { baan- } \\
\text { openingen }\end{array}$ & $\begin{array}{l}\text { arbeidsmark } \\
\text { instroom }\end{array}$ \\
\hline Bouwvakkers & 1,03 & enige & gemiddeld & gemiddeld \\
\hline Mechanisch operators & 1,03 & enige & gemiddeld & gemiddeld \\
\hline Commercieel employés & 1,03 & enige & gemiddeld & hoog \\
\hline Programmeurs & 1,02 & enige & gemiddeld & erg hoog \\
\hline \multicolumn{5}{|c|}{ Activiteitenbegeleiders en medewerkers } \\
\hline arbeidsbemiddeling & 1,02 & enige & gemiddeld & erg hoog \\
\hline Winkeliers & 1,02 & enige & gemiddeld & gemiddeld \\
\hline \multicolumn{5}{|l|}{ Politieagenten, onderofficieren en } \\
\hline beveiligingsemployés & 1,02 & enige & gemiddeld & gemiddeld \\
\hline Metaalarbeiders & 1,01 & enige & gemiddeld & gemiddeld \\
\hline Agrarische bedrijfshoofden & 1,00 & enige & gemiddeld & gemiddeld \\
\hline Boekhouders en secretaresses & 1,00 & enige & gemiddeld & hoog \\
\hline
\end{tabular}

Bron: ROA 


\subsection{Vraaggericht scholingsbeleid}

\section{Vraagoverschot}

Het verschil tussen de verwachte baanopeningen en de openstaande vacatures aan de ene kant en het verwachte aantal schoolverlaters en direct inzetbare niet-werkende werkzoekenden $^{20}$ aan de andere kant geeft een indicatie van het vraagoverschot voor de betreffende beroepsgroep. Het vraagoverschot is van twee factoren afhankelijk. In de eerste plaats van de ernst van de verwachte knelpunten. Hoe groter de knelpunten, hoe groter het vraagoverschot vanuit werkgeversoptiek zal zijn. In de tweede plaats is het verwachte vraagoverschot (in aantallen personen) afhankelijk van de omvang van het arbeidsmarktsegment. Bestaande of verwachte vraagoverschotten kunnen, tot op zekere hoogte, op verschillende manieren worden verholpen of voorkomen. Daarbij kan gedacht worden aan scholing, het bevorderen van de internationale pendel of het inzetten van de stille arbeidsreserve.

In tabel 3.5 wordt een overzicht gegeven van de beroepsgroepen, op middelbaar of lager niveau, waarvoor er sprake is van een vraagoverschot, gezien de verwachte knelpunten in de personeelsvoorziening in 2000 in Limburg. Daarnaast geeft de tabel aan hoeveel nietwerkende werkzoekenden in fase 2 en 3 er beschikbaar zijn (afgerond op 50-tallen).

De tabel laat zien dat er sprake is van een aanzienlijk vraagoverschot. De kloof van 9.300 arbeidskrachten over het totaal van de lagere en middelbare beroepsgroepen betekent een aanzienlijke toename ten opzichte van het vraagoverschot van 5.300 personen, zoals die in het vorige RAIL-rapport in kaart werd gebracht (in het vorige rapport werd hiervoor nog de naam 'scholingsbehoefte' gehanteerd). Het verwachte vraagoverschot voor 2000 houdt bijna een verdubbeling in. Voor de niet-werkende werkzoekenden met een grotere afstand tot de arbeidsmarkt zullen er dus meer mogelijkheden zijn om werk te vinden na het volgen van een scholingstraject. Gezien het aanbodtekort zullen werkgevers zich in toenemende mate moeten richten op dit onbenutte potentieel aan arbeidskrachten. De sterke toename van het vraagoverschot wijst op het grote belang van een anticiperend scholingsbeleid teneinde grote knelpunten in de personeelsvoorziening te voorkomen.

Tabel 3.5 biedt daarbij een richtinggevend kader voor een arbeidsmarkıconform 'vraaggericht' scholingsbeleid. Dit scholingsbeleid ter voorkoming van knelpunten in de personeelsvoorziening zal zich moeten richten op een groot aantal uiteenlopende beroepsgroepen: beroepen in de dienstensector, maar ook verzorgende beroepen en een aantal lagere en middelbaar technische beroepen. De beroepsgroep verkopers, die werd gekenmerkı door een groot aantal baanopeningen, voert de lijst aan, met een totaal vraagoverschot van meer dan 2.000. Dit betekent dat met het scholen van 2.000 niet-werkende werkzoekenden in fase 2 en 3 het verwachte tekort aan direct inzetbare werkzoekenden voor verkopers voorkomen kan worden. Het aantal niel-werkende werkzoekenden in fase 2 en 3 van 900 is hiervoor dus niet voldoende. Andere beroepsgroepen waarbij er sprake is van een groot absoluut vraagoverschot zijn receptionisten en administratieve employés, chauffeurs, monteurs

20 Het gaat hier om de niet-werkende werkzoekenden die door Arbeidsvoorziening zijn ingedecld in fase I. 
Tabel 3.5

Verwachte vraagoverschot naar beroepsgroep in 2000 in Limburg

Beroepsgroep

$\begin{array}{lrr}\text { vraagoverschot } \begin{array}{r}\text { aantal } \\ \text { werkenden } \\ \text { zoekenden } \\ \text { fase } 2 \text { en } 3\end{array} & \text { vereist opleidingstype }\end{array}$

fase 2 en 3

\begin{tabular}{|c|c|c|c|c|}
\hline Verkopers & 2.150 & 19.000 & 900 & MBO handel \\
\hline $\begin{array}{l}\text { Receptionisten en administratieve } \\
\text { employés }\end{array}$ & 1.450 & 16.500 & 450 & $\begin{array}{l}\text { MBO administratie, } \\
\text { MBO secretariaat }\end{array}$ \\
\hline Hulpkrachten horeca en verzorging & 1.150 & 11.500 & 1.050 & $\begin{array}{l}\text { VMBO (uiterlijke) } \\
\text { verzorging }\end{array}$ \\
\hline Interieurverzorgers & 900 & 12.500 & 1.100 & $\begin{array}{l}\text { VMBO (uiterlijke) } \\
\text { verzorging }\end{array}$ \\
\hline Aannemers en installateurs & 550 & 11.500 & 150 & $\begin{array}{l}\text { MBO bouw, } \\
\text { MBO installatietechniek }\end{array}$ \\
\hline Assembleurs & 500 & 4.500 & 200 & $\begin{array}{l}\text { MBO motorvoertuigen } \\
\text { techiniek }\end{array}$ \\
\hline Verzorgend personeel & 450 & 14.500 & 300 & $\begin{array}{l}\text { MBO verzorging, MBO } \\
\text { (uiterlijke) verzorging }\end{array}$ \\
\hline Procesoperators & 300 & 6.500 & 50 & MBO procestechniek \\
\hline Chauffeurs & 300 & 19.500 & 1.150 & $\begin{array}{l}\text { VMBO transport en } \\
\text { techniek }\end{array}$ \\
\hline Productiemedewerkers & 250 & 8.500 & 2.500 & - \\
\hline Bankwerkers en lassers & 250 & 6.000 & 350 & $\begin{array}{l}\text { MBO werktuigb. en } \\
\text { mech. techniek }\end{array}$ \\
\hline Productieplanners & 200 & 3.000 & antal - & MBO administratie \\
\hline Monteurs & 150 & 18.500 & 100 & $\begin{array}{l}\text { MBO motorvoertuigen } \\
\text { techniek, MBO werktuigb. } \\
\text { en mech. techniek, } \\
\text { MBO elektrotechniek }\end{array}$ \\
\hline Elektromonteurs & 150 & 7.000 & 50 & MBO elektrotechniek \\
\hline $\begin{array}{l}\text { Kantoorhulpen, inpakkers } \\
\text { en colporteurs }\end{array}$ & 150 & 4.500 & 950 & - \\
\hline Ziekenverzorgenden & 150 & 5.000 & - & MBO verzorging \\
\hline $\begin{array}{l}\text { Weg- en waterbouwkundige } \\
\text { vakkrachten }\end{array}$ & 100 & 2.500 & - & $\begin{array}{l}\text { MBO grond-, weg- en } \\
\text { waterbouw }\end{array}$ \\
\hline Laders en lossers & 100 & 6.500 & 250 & - \\
\hline Totaal & 9.300 & 177.500 & 9.500 & \\
\hline
\end{tabular}

Bron: $R O A$

en verzorgend personeel, en ook voor deze beroepen geldt dat het potentieel aan fase 2 en 3 werkzoekenden ontoereikend is om in de restvraag te voorzien. Er is voor verkopers niet alleen een grote absolute behoefte, ook het vraagoverschot als percentage van het aantal werkenden is groter dan voor elk ander beroep. Wil men bij de verkopers knelpunten in de 
personeelsvoorziening voorkomen, dan zal men een contingent niet-werkende werkzoekenden in fase 2 en 3 moeten scholen ter grootte van $11 \%$ van het aantal werkenden. Een anticiperend scholingsbeleid gericht op deze doelgroep is derhalve van groot belang. Andere beroepsgroepen met een relatief groot vraagoverschot zijn de assembleurs (11\%), de hulpkrachten horeca en verzorging (10\%) en de receptionisten en administratieve employés $(9 \%)$.

\section{Bijscholing}

Bijscholing kan een belangrijk instrument zijn om de arbeidsmarktkansen van nietwerkende werkzoekenden in fase 2 en 3 te vergroten. De verwachte knelpunten in de personeelsvoorziening voor de beroepsgroep waarin deze werkzoekenden op zoek zijn naar een baan spelen vanzelfsprekend een belangrijke rol voor het perspectief dat scholingsprojecten voor deze groepen kunnen hebben. Wanneer er sprake is van een ruime arbeidsmarkt zijn er immers voldoende direct inzetbare werkzoekenden beschikbaar, waardoor scholing van de niet-werkende werkzoekenden in fase 2 en 3 weinig perspectiefvol is. Wanneer er daarentegen op een bepaald arbeidsmarktsegment sprake is van krapte en er grote knelpunten in de personeelsvoorziening verwacht worden, kan scholing de niet-werkende werkzoekenden met een grotere afstand tot de arbeidsmarkt een goed perspectief bieden op het vinden van werk.

Naast de vraag of er sprake is van verwachte knelpunten, speelt ook de aard van de knelpunten een rol. Wanneer voor een bepaalde beroepsgroep met knelpunten in de personeelsvoorziening het aantal niet-werkende werkzoekenden met een grotere afstand tot de arbeidsmarkt tekortschiet om de resterende baanopeningen in te vullen, dan is er sprake van een kwantitatief tekort aan werkzoekenden. In dat geval zullen de bijscholingsmogelijkheden voor individuele werkzoekenden in fase 2 en 3 naar verwachting groot zijn. De bijscholingsmogelijkheden-indicator (BSM), d.w.z. de verhouding tussen het aantal niet-werkende werkzoekenden in fase 2 en 3 en de (resterende) vraag die niet door schoolverlaters en nietwerkende werkzoekenden in fase 1 kan worden vervuld, is dan kleiner dan één.

In tabel 3.5 wordt tevens aangegeven welke opleidingsachtergrond het best aansluit op de gevraagde kwalificaties in de betreffende beroepsgroepen. Uit de tabel komt duidelijk naar voren dat de vraagoverschotten vooral de aandacht richten op opleidingen op MBO-niveau. Gezien het feit dat we ons beperken tot de lagere en middelbare beroepen hoeft dit geen verbazing te wekken. Voor steeds meer uitvoerende beroepen in zowel de industrie als de dienstensector is minimaal een opleiding op MBO-niveau vereist. Het bijscholen gericht op het verhogen van de kwalificaties van niet-werkende werkzoekenden met een grotere afstand tot de arbeidsmarkt dient zich dus met name te concentreren op opleidingen op MBO-niveau. De knelpunten in de personeelsvoorziening voor het beroep procesoperator kunnen voornamelijk voorkomen worden door het opschroeven van de scholingsinspanningen op het niveau van het opleidingstype $M B O$ procestechnieh. We zien dat het vraagoverschot zich in Limburg in het jaar 2000 vooral richt op technische opleidingen, zoals MBO installatietechniek, MBO elektrotechniek en $M B O$ werktuigbouw en mechanische technick, de administratieve opleidingen, de verzorgende en verplegende opleidingen en de bouw-opleidingen. 
In tabel 3.6 wordt een overzicht gegeven van de beroepsgroepen die gekenmerkt worden door goede bijscholingsmogelijkheden voor niet-werkende werkzoekenden op het desbetreffende arbeidsmarktsegment met een grotere afstand tot de arbeidsmarkt. De bijscholingsmogelijkheden voor niet-direct inzetbare werkzoekenden zijn het grootst voor de beroepsgroepen productieplanners en ziekenverzorgenden. Voor elke honderd baanopeningen in deze beroepen, die niet door direct inzetbare werkzoekenden kunnen worden vervuld, zijn er 6 respectievelijk 7 niet-werkende werkzoekenden met een grotere afstand tot de arbeidsmarkt beschikbaar. Voor niet-werkende werkzoekenden in fase 2 en 3 zijn de bijscholingsperspectieven in deze beroepsgroepen derhalve groot. Er zijn immers veel minder werkzoekenden beschikbaar dan er nodig zijn om de verwachte tekorten op te vullen. Vanuit het oogpunt van de werkgevers kunnen we echter ook zeggen dat er voor de beroepen in tabel 3.6 te weinig niet-werkende werkzoekenden in fase 2 en 3 aanwezig zijn om de tekorten via bijscholing op te kunnen vullen.

In tabel 3.6 wordt tevens aangegeven welk karakter de bijscholing dient te hebben om zo goed mogelijk aan te sluiten bij de (vakinhoudelijke) lacunes van de niet-werkende werkzoekenden in fase 2 en 3 op het betreffende arbeidsmarktsegment. Het precieze karakter verschilt per beroepsgroep en kan betrekking hebben op de mogelijkheid werk- dan wel praktijkervaring op te doen, maar kan bijvoorbeeld ook gericht zijn op het aanbieden van

Tabel 3.6

\section{Beroepsgroepen met naar verwachting goede bijscholingsmogelijkheden (BSM) voor individuele werkzoekenden in 2000 in Limburg}

\begin{tabular}{|c|c|c|c|}
\hline Beroepsgroep & BSM & MBO-opleidingstype & aard bijscholing \\
\hline Productieplanners & 0,06 & administratie & - \\
\hline Ziekenverzorgenden & 0,07 & verzorging & ervaring opdoen \\
\hline Procesoperators & 0,21 & procestechniek & $\begin{array}{l}\text { niveau verhogen, ervaring } \\
\text { opdoen }\end{array}$ \\
\hline Elektromonteurs & 0,23 & elektrotechniek & vakkennis vergroten \\
\hline $\begin{array}{l}\text { Weg- en waterbouwkundige } \\
\text { vakkrachten }\end{array}$ & 0,23 & grond-, weg- en waterbouw & - \\
\hline Aannemers en installateurs & 0,29 & bouw, installatietechniek & ervaring opdoen \\
\hline Receptionisten en adm. employés & 0,31 & administratie, secretariaat & $\begin{array}{l}\text { ervaring opdoen, } \\
\text { niveau verhogen }\end{array}$ \\
\hline Verkopers & 0,41 & handel & productkennis vergraten \\
\hline Assembleurs & 0,44 & motorvoertuigentechniek & - \\
\hline Monteurs & 0,55 & $\begin{array}{l}\text { motorvoertuigentechniek, } \\
\text { werktuigb. en mechanische } \\
\text { techniek, elektratechniek }\end{array}$ & vakkennis verbreden \\
\hline Verzorgend personeel & 0,68 & (uiterlijke) verzorging & ervaring opdoen \\
\hline Hulpkrachten horeca en verzorging & 0,94 & (uiterlijke) verzorging & niveau verhogen \\
\hline
\end{tabular}


cursussen om de kennis te verbreden. Uit een recente analyse ${ }^{21}$ van de belemmeringen die de niet-direct inzetbare werkzoekenden hebben om werk te vinden, blijkt dat er bij $60 \%$ van de niet-werkende werkzoekenden die zijn ingedeeld in fase 2 of 3 sprake is van een tekortschietende opleiding, terwijl $40 \%$ een gebrekkige werkervaring heeft. Tevens beschikt $40 \%$ over ontoereikende sollicitatievaardigheden.

Knelpunten in de personeelsvoorziening kunnen ook het gevolg zijn van een kwalitatief aansluitingsprobleem bij een bepaald beroep. In dat geval zijn er voor die beroepsgroep voldoende niet-werkende werkzoekenden in fase 2 en 3 beschikbaar om de baanopeningen die niet door schoolverlaters en werkzoekenden in fase 1 kunnen worden vervuld in te vullen. Deze werkzoekenden voldoen echter niet aan de eisen die op het betreffende arbeidsmarktsegment worden gesteld. Het probleem is dus kwalitatief van aard. De bijscholingsmogelijkheden-indicator (BSM), die het bijscholingspotentieel in verhouding tot het vraagoverschot weergeeft, is dan groter dan één. Dit geeft aan dat slechts een deel van de niet-werkende werkzoekenden in fase 2 en 3 door bijscholing een baan zal kunnen krijgen.

In tabel 3.7 wordt een overzicht gegeven van de beroepsgroepen waarvoor er sprake is van een kwalitatief aansluitingsprobleem, waardoor de bijscholingsmogelijkheden voor individuele werkzoekenden die zijn ingedeeld in fase 2 of 3 dus relatief beperkt zijn. Voor de werkgevers in deze beroepsgroepen geldt daarentegen dat ze bij een gericht bijscholingsbeleid in principe kunnen vissen in een betrekkelijk grote vijver. Uit de tabel blijkt dat dit in 2000 naar verwachting voornamelijk het geval is voor productiemedewerkers en kantoorhulpen, inpakkers en colporteurs. Deze twee beroepsgroepen hebben te kampen met een groot overschot aan niet-werkende werkzoekenden met een grotere afstand tot de arbeidsmarkt. Voor alle honderd baanopeningen die resteren nadat gebruik is gemaakt van niet-werkende

\section{Tabel 3.7}

Beroepsgroepen met naar verwachting grote knelpunten in de personeelsvoorziening, maar beperkte bijscholingsmogelijkheden (BSM) voor individuele werkzoekenden in 2000 in Limburg

\begin{tabular}{lrll} 
Beroepsgroep & BSM & (V)MBO-opleidingstype & aard bijscholing \\
\cline { 4 - 5 } Productiemedewerkers & & & - \\
Kantoorhulpen, inpakkers en colporteurs & 6,81 & - & - \\
Chauffeurs & 3,83 & transport en techniek & - \\
Laders en lossers & 2,71 & - & - \\
Bankwerkers en lassers & 1,53 & werktuigb. en mechanische & niveau verhogen, \\
& & techniek & ervaring opdoen \\
Interieurverzorgers & 1,19 & (uiterlijke) verzorging & niveau verhogen, \\
& & & werkmentaliteit
\end{tabular}

Bron: ROA/ETIL

21 Zie Aanbodanalyse 1999: Belemmeringen en Kansen, Arbeidsvoorziening Limburg. Siltard, 1999 
werkzoekenden die direct inzetbaar zijn, zijn er respectievelijk 1.015 en 681 niet-werkende werkzoekenden in fase 2 en 3 beschikbaar. Het potentieel aan werkzoekenden waaruit geput kan worden en dat bijgeschoold kan worden is dus erg groot en biedt de werkgever veel soelaas. Voor de individuele werkzoekende met een relatief grote afstand tot de Limburgse arbeidsmarkt geldt echter ook dat het volgen van een bijscholingstraject, gericht op de beroepsgroep waarin men naar werk zoekt, weinig zekerheid biedt op het verkrijgen van een baan.

Ook voor chauffeurs en laders en lossers geldt dat de bijscholingsmogelijkheden voor de niet- werkende werkzoekenden in fase 2 en 3 relatief beperkt zullen zijn, aangezien het aantal werkzoekenden twee keer zo groot is als het marktconforme vraagoverschot.

Net als voor de beroepsgroepen met naar verwachting grote knelpunten in de personeelsvoorziening en goede bijscholingsmogelijkheden, uit tabel 3.6, wordt ook hier een indicatie gegeven welk karakter de bijscholing dient te hebben. Een voorbeeld: Uit interviews en panels ${ }^{22}$ blijkt dat voor interieurverzorgers vooral werkmentaliteit en plezier in de dienstverlening van belang zijn bij het uitoefenen van dit beroep. Formele opleidingskwalificaties worden niet genoemd. Om het tekort aan mensen op te vullen kan worden geworven onder migranten, asielzoekers en allochtonen, maar ook onder herintredende vrouwen en nietwerkende werkzoekenden. Hierbij heeft wel elke categorie haar eigen voors en tegens:

Migranten etc.

Herintredende vrouwen

Niet-werkende werkzoekenden
- vaak gemotiveerd

- taal- en cultuurproblemen

- weinig ervaring.

- groot verantwoordelijkheidsgevoel

- vragen vaste uren, wat moeilijk is binnen de sector

- onveiligheid avonduren, woon-werkverkeer.

- vaak ongemotiveerd

- beperkte representativiteit en sociale vaardigheden.

\section{Omscholing}

Wanneer er sprake is van een kwantitatief aansluitingsprobleem, dan is bijscholing van de niet-werkende werkzoekenden in fase $2 \mathrm{en} 3$ voor het betreffende beroep niet toereikend om de verwachte knelpunten in de personeelsvoorziening te voorkomen. In dat geval is omscholing van niet-werkende werkzoekenden op een enigszins verwant beroepssegment noodzakelijk om in de vraag te voorzien. Deze mensen zullen vanzelfsprekend moeten worden aangetrokken uit arbeidsmarktsegmenten waarvoor geen knelpunten in de personeelsvoorziening verwacht worden. Het omscholen van arbeidskrachten uit segmenten waarvoor eveneens sprake is van knelpunten is immers weinig efficiënt. 
In tabel 3.8 wordt voor de beroepsgroepen die naar verwachting in 2000 te kampen zullen hebben met een kwantitatief aanbodtekort aangegeven welke niet-werkende werkzoekenden die zijn opgeleid voor een verwant beroep voor omscholing in aanmerking zouden kunnen komen. Hierbij wordt ook aangegeven op welke beroepsgroepen deze scholing gericht zou dienen te zijn.

\section{Tabel 3.8}

Mogelijkheden ter voorkoming van de knelpunten in de personeelsvoorziening door middel van omscholing in 2000 in Limburg

Beroepsgroep

Productieplanners

Ziekenverzorgenden

Procesoperators

Elektromonteurs

Weg- en waterbouwkundige vakkrachten Aannemers en installateurs

Receptionisten en adm. employés

Verkopers

Assembleurs

Monteurs

Verzorgend personeel

Hulpkrachten horeca en verzorging

omscholing vanuit

MBO-opleidingstype

\begin{tabular}{ll} 
verpleeghulpen & $\begin{array}{l}\text { administratie } \\
\text { verzorging } \\
\text { procestechniek } \\
\text { - }\end{array}$ \\
$\begin{array}{ll}\text { controleurs elektro- } \\
\text { technische producten }\end{array}$ & grond-, weg-en waterbouw \\
- & bouw, installatietechniek \\
- & administratie, secretariaat \\
- & handel \\
- & motorvoertuigentechniek \\
elektrotechnici, & motorvoertuigentechniek, \\
controleurs elektro- & werktuigb. en mech. techniek, \\
techn. producten & elektrotechniek \\
- & (uiterlijke) verzorging \\
- & (uiterlijke) verzorging \\
\hline
\end{tabular}

Bron: ROA

Voor een aantal beroepsgroepen blijken er echter geen werkzoekenden uit verwante beroepsgroepen beschikbaar te zijn. Bij verwante beroepsgroepen is er dan ook sprake van knelpunten in de personeelsvoorziening en biedt scholing dus op de korte termijn geen soelaas om de knelpunten in de personeelsvoorziening te verminderen. Voor de monteurs, elektromonteurs en aannemers en installateurs geld dat er voor veel aanverwante beroepsgroepen ook sprake is van grote knelpunten in de personeelsvoorziening. Uitzonderingen zijn elektrotechnici en controleurs elektrotechnische producten. Bij de ziekenverzorgenden en verzorgend personeel is er sprake van een vergelijkbare problematiek. Voor ziekenverzorgenden en verzorgend personeel zijn er echter voldoende potentiële en omschoolbare arbeidskrachten beschikbaar. Daarbij gaat het om werkzoekenden verpleeghulpen en leerling verpleegkundigen.

Bij gebrek aan omschoolbare niet-werkende werkzoekenden uit andere beroepsgroepen, moet bij de omscholingsmogelijkheden vooral gedacht worden aan het substantieel verhogen van het kwalificatieniveau van de lager geschoolden en het stimuleren van de arbeidsmarktparticipatie van goed gekwalificeerde vrouwen, zoals ook vorig jaar reeds werd aangegeven. 


\subsection{Aandachtspunten voor het scholingsbeleid}

Samenvattend kan gesteld worden dat bij- en omscholing van niet-werkende werkzoekenden in principe een effectief middel kan zijn om de verwachte discrepanties tussen vraag en aanbod op de Limburgse arbeidsmarkt te verminderen. Door middel van bijscholing kunnen aansluitingsproblemen tussen de kennis en vaardigheden waarover de werkzoekenden op een bepaald arbeidsmarktsegment beschikken en de in dat segment gevraagde kennis en vaardigheden verminderd worden. Met andere woorden: bijscholing kan een effectief middel zijn om kwalitatieve aansluitingsproblemen in een bepaald arbeidsmarktsegment het hoofd te bieden. Door middel van omscholing kunnen knelpunten op de arbeidsmarkt worden bestreden, die niet kunnen worden opgelost door het bijscholen van het nietdirect inzetbare arbeidsaanbod voor de desbetreffende beroepsgroep. Omscholing van nietwerkende werkzoekenden die zijn opgeleid voor een beroepsgroep waarvoor er sprake is van een overschot, kan dus een effectief middel zijn om kwantitatieve aansluitingsproblemen op andere arbeidsmarktsegmenten te verminderen. Aansluitingsproblemen hebben overigens niet alleen betrekking op vakinhoudelijke kennis en vaardigheden. Ook werkhouding, communicatieve vaardigheden, de wil om te blijven leren, een klantvriendelijke instelling, e.d. spelen een belangrijke rol.

Een marktconform scholingsbeleid zal zich dienen te concentreren op het vergroten van het direct inzetbare arbeidsaanbod in beroepsgroepen uit de segmenten techniek, bouw en administratie. Voor de beroepsgroepen uit tabel 3.7 geldt dat met name kwalitatieve discrepanties debet zijn aan het tekort aan niet-werkende werkzoekenden in fase 1. Bijscholing van niet-werkende werkzoekenden met een grotere afstand tot de arbeidsmarkt zou de in 2000 verwachte knelpunten in de personeelsvoorziening in deze beroepen kunnen voorkomen. Zoals we in tabellen 3.6 en 3.8 zagen, wordt er ook voor een aantal beroepsgroepen een kwantitatief aansluitingsprobleem verwacht. In deze gevallen zal alleen een combinatie van bij- en omscholingstrajecten soelaas kunnen bieden.

Tabel 3.9 geeft een samenvattend overzicht van de gewenste aandachtspunten voor het scholingsbeleid in 2000, verbijzonderd naar de opleidingstypen waarop de scholing zich zou moeten richten, de beroepsgroepen waarvoor ze opleiden, de aard van de gewenste bijscholing en de niet-werkende werkzoekenden die zijn opgeleid voor een verwant beroep die voor omscholing in aanmerking komen. 

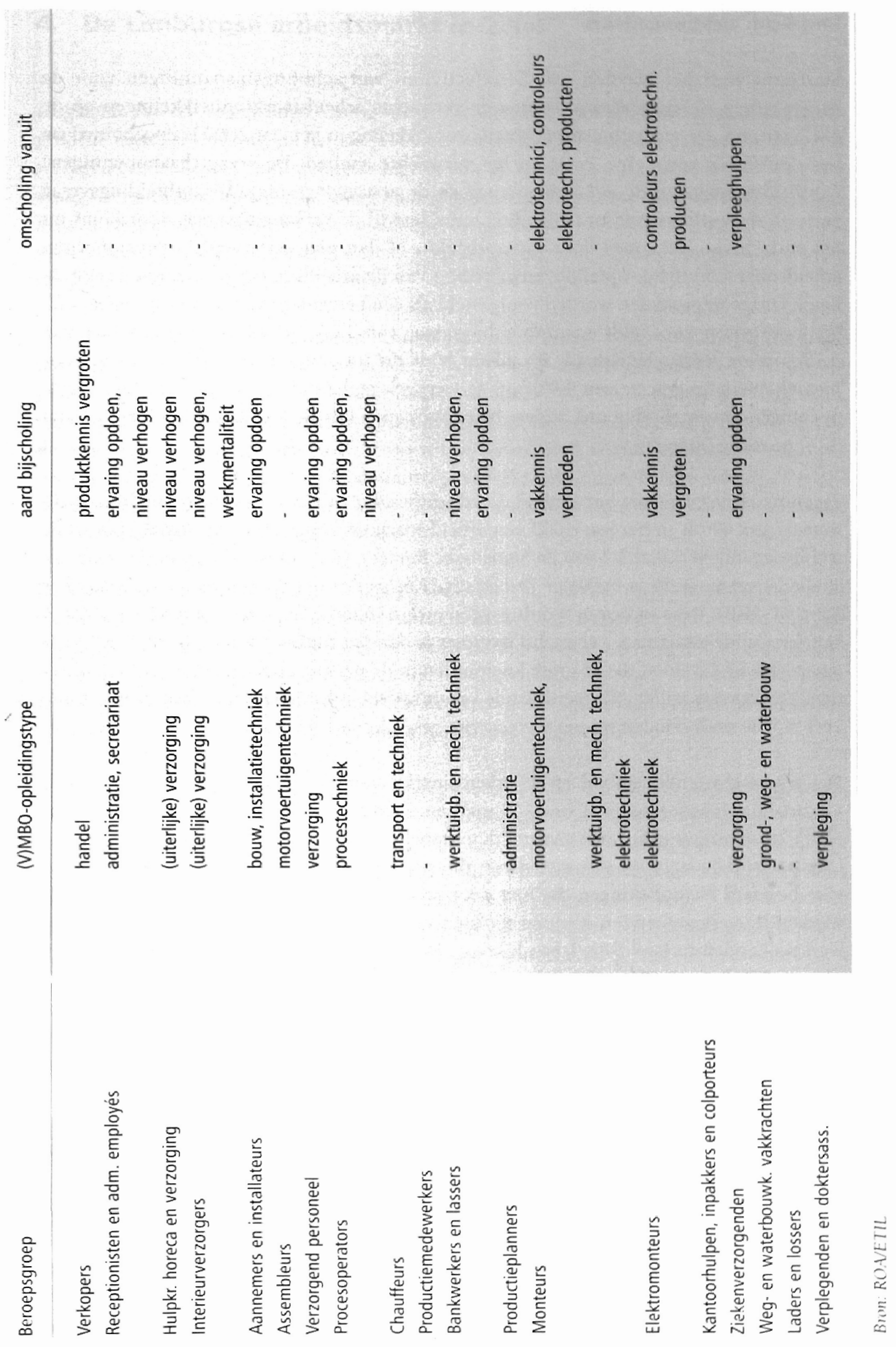


\section{Uitgelicht: elektromonteurs}

Startpunt voor het bepalen van de effectiviteit van scholingsinspanningen voor de beroepsgroep elektromonteurs vormen de verwachte arbeidsmarktontwikkelingen op de korte termijn. De verwachte arbeidsmarktontwikkeling in het jaar 2000 is opgebouwd uit twee delen: de verwachte vraag en het verwachte aanbod. De vraag (baanopeningen) wordt uitgesplitst in de uitbreidingsvraag en de vervangingsvraag. De uitbreidingsvraag geeft de werkgelegenheidsontwikkeling weer, terwijl de vervangingsvraag voortkomt uit het vertrek van personeel door bijvoorbeeld - al dan niet vervroegde - pensionering, arbeidsongeschiktheid, tijdelijke terugtreding van de arbeidsmarkt en beroepsmobiliteit. Beide vraagcomponenten worden voorgesteld als een percentage van de werkgelegenheid. Voor elektromonteurs geldt een uitbreidingsvraag van $2,2 \%$ en een vervangingsvraag van $3,7 \%$ van de werkgelegenheid. Bij elkaar leidt dit tot een aantal baanopeningen voor nieuwkomers ter grootte van $5,9 \%$ van de werkgelegenheid. Dit is een hoog aantal baanopeningen in vergelijking met andere beroepsgroepen (zie de tabellen 3.2, 3.3 en 3.4 van de Statistische Bijlage).

Tegenover de vraag staat het aanbod, i.c. de verwachte arbeidsmarktinstroom. Voor elektromonteurs wordt in het jaar 2000 een arbeidsmarktinstroom verwacht van $4,1 \%$ van de werkgelegenheid (tabel 3.5 van de Statistische Bijlage). Het confronteren van de vraag- en aanbodstromen geeft de Indicator Toekomstige Knelpunten in de personeelsvoorziening naar Beroep (ITKB). Deze indicator wordt gepresenteerd in tabel 3.6 van de Statistische Bijlage. Het feit dat de vraag naar verwachting groter is dan het aanbod (waardoor de ITKB kleiner is dan 1), betekent dat er grote knelpunten in de personeelsvoorziening zullen optreden. Werkgevers zullen bij openstaande vacatures voor elektromonteurs naar verwachting veel moeite ondervinden bij het werven van geschikt personeel.

Het tekortschietende aanbod op de arbeidsmarkt voor elektromonteurs resulteert in een aanzienlijk vraagoverschot. Circa 150 mensen zouden moeten worden bijgeschoold om als elektromonteur te kunnen gaan werken (tabel 3.5). In tabel 3.6 zien we dat de bijscholingsmogelijkheden voor elektromonteurs die zijn ingedeeld in fase 2 of 3 goed zijn. Voor elke honderd baanopeningen die niet door schoolverlaters of direct bemiddelbare nietwerkende werkzoekenden kunnen worden vervuld, zijn er slechts 23 niet-werkende werkzoekenden in fase 2 en 3 beschikbaar. De bijscholing van deze groep overgebleven niet-werkende werkzoekenden zal met name gericht moeten zijn op het verbreden van de vakkennis van niet-werkende werkzoekenden met een technische opleidingsachtergrond. Te denken valt aan de opleiding MBO elektrotechniek. Voor de resterende baanopeningen zouden werkzoekenden die voor een ander beroep staan ingeschreven, moeten worden omgeschoold. Gezien de krapte op verwante segmenten van de arbeidsmarkt is het moeilijk hiervoor geschikte mensen te vinden. Mogelijk zou geworven kunnen worden onder de niet-werkende werkzoekenden die staan ingeschreven voor de beroepsgroep controleurs elektrotechnische produkten. 


\section{De Limburgse arbeidsmarkt in 2004}

Uitgaande van een voorzichtige raming van de economische groei in Limburg zal de werkgelegenheid, naar verwachting, tot het jaar 2004 gemiddeld jaarlijks met 0,5\% toenemen. Naast de werkgelegenheidsgroei (uitbreidingsvraag) is ook de arbeidsmarktuitstroom (vervangingsvraag) verantwoordelijk voor de vraag naar nieuwe arbeidskrachten. Met name de werkzoekenden en schoolverlaters met een opleidingsachtergrond passend bij de meer conjunctuurgevoelige bedrijfssectoren zullen de gevolgen van de teruggang in de economische groei merken bij het zoeken naar een baan.

Ook de komende jaren zal het aanbod achterblijven bij de vraag. Naar verwachting zal er per jaar een arbeidsmarktinstroom van schoolverlaters op de Limburgse arbeidsmarkt zijn ter grootte van ongeveer $4 \%$ van het huidige aantal werkenden. Net als in de rest van Nederland, zal er daarnaast sprake zijn van een up-gradingsproces, dat wil zeggen een verhoging van de gestelde (opleidings-) eisen aan nieuw te werven personeel. Er is daardoor met name veel vraag naar hoger opgeleiden; economisch-administratieve HBO-opleidingen hebben relatief de grootste aantallen baanopeningen. Op het $\mathrm{MBO}$-niveau is vooral veel vraag naar schoolverlaters van de op dienstverlening gerichte opleidingen.

De confrontatie van de verwachte vraag en het verwachte aanbod geeft een indicatie van de kansen van schoolverlaters op de arbeidsmarkt. Gunstige vooruitzichten zijn er voor de hoger opgeleiden. Bij de economisch-administratieve en de informatica-opleidingen kan zelfs gesproken worden van zeer gunstige arbeidsmarktperspectieven. Voor de lager-en middelbaar opgeleiden geldt dat vooral schoolverlaters van de verzorgende opleidingen in 2004 betrekkelijk eenvoudig een goed bij hun opleiding aansluitende baan zullen vinden.

Naast verwachte perspectieven is het van belang rekening te houden met een aantal risico-factoren. De conjunctuurgevoeligheid van de werkgelegenheid en de uitwijkmogelijkheden op de arbeidsmarkt zijn twee van dergelijke risico-factoren. Wanneer de arbeidsmarktperspectieven gekoppeld worden aan deze twee risico-factoren, blijkt dat met name degenen met een opleiding MBO administratie of MBO secretariaat een sterke arbeidsmarktpositie hebben. Een vergroting van de populariteit van deze opleidingen - eventueel gekoppeld aan een vergroting van de capaciteit - kan een zeer effectief middel zijn om de zgn. macrodoelmatigheid van het onderwijs in Limburg te vergroten.

\subsection{Inleiding}

In dit hoofdstuk zal aandacht worden besteed aan de verwachte arbeidsmarktontwikkelingen in Limburg tot 2004. Net als in het vorige hoofdstuk, kan aan de hand van prognoses van de toekomstige vraag en het toekomstige aanbod van arbeidskrachten een inventarisatie worden gemaakt van de eventuele toekomstige tekorten.

In paragraaf 4.2 word $t$ voor de verschillende opleidingen een indicatie gegeven van de verwachte toekomstige arbeidsmarktpositie van schoolverlaters in 2004. Deze informatie kan een bruikbare leidraad vormen voor degenen die op dit moment voor een studiekeuzebeslissing staan teneinde hun kansen op de arbeidsmarkı goed te kunnen inschatten. 
Immers, degenen die dit jaar met een opleiding beginnen zullen in 2004 of daaromtrent voor het eerst op zoek gaan naar een baan. Daarnaast kan de informatie door werkgevers en degenen die betrokken zijn bij het arbeidsmarkt- of onderwijsbeleid worden gebruikt om te anticiperen op de toekomstige situatie op de arbeidsmarkt. Paragraaf 4.3 geeft een soortgelijk overzicht van de verwachte arbeidsmarktperspectieven voor de hoger opgeleiden. In paragraaf 4.4 wordt aan de hand van het arbeidsmarktperspectief en een tweetal risico-indicatoren een typologie gegeven van de arbeidsmarktkansen die de verschillende opleidingen bieden. Dit wederom voor de schoolverlaters op lager en middelbaar niveau. Het hoofdstuk wordt afgesloten met paragraaf 4.5 waarin nader wordt ingegaan op de aandachtspunten voor het onderwijsbeleid die uit de in dit hoofdstuk gepresenteerde informatie naar voren komen.

\subsection{Arbeidsmarktperspectieven van schoolverlaters in $\mathbf{2 0 0 4}$}

De toekomstige arbeidsmarktperspectieven van schoolverlaters zijn het resultaat van ontwikkelingen aan zowel de vraag- als aanbodzijde van de arbeidsmarkt. Daarbij gaat het in essentie om een vergelijking van het aantal baanopeningen voor nieuwkomers op de arbeidsmarkt en de arbeidsmarktinstroom. Dit betekent dat er geen één-op-één relatie bestaat tussen het aantal baanopeningen en de toekomstige arbeidsmarktperspectieven. Zo kan er bij een gering aantal baanopeningen sprake zijn van goede arbeidsmarktperspectieven, wanneer de arbeidsmarktinstroom op een nog lager niveau ligt.

\section{Baanopeningen}

In tabel 4.1 zijn de opleidingstypen met relatief de grootste aantallen verwachte baanopeningen in Limburg tot 2004 in kaart gebracht. Daarnaast is het percentage baanopeningen voor deze opleidingstypen in heel Nederland weergegeven ${ }^{23}$.

Economisch-administratieve $\mathrm{HBO}$-opleidingen, zoals $\mathrm{HBO}$ secretariaat, $\mathrm{HBO}$ commerciële economie, HBO accountancy en bedrijfseconomie, voeren de boventoon. Het grote aantal baanopeningen voor mensen met deze opleidingen heeft niet altijd dezelfde opbouw. Voor HBO secretariaat geldt dat het grote aantal baanopeningen met name veroorzaakt wordt door de hoge vervangingsvraag vanwege een hoge arbeidsmarktuitstroom. Bij HBO commerciele economie daarentegen is het hoge percentage baanopeningen vooral toe te schrijven aan een hoge uitbreidingsvraag.

Op MBO-niveau zijn de baanopeningen, als percentage van de werkgelegenheid, naar verwachting het hoogst voor de op de dienstverlening gerichte opleidingen. De baanopeningen voor deze opleidingen kunnen niet eenduidig worden toegeschreven aan een hoge

23 Opgemerkt zij dat voor Nederland als geheel andere typeringsgrenzen worden gehanteerd dan voor Limburg, omdat de typering nu eenmaal een relatieve maat is, en dit kan er toe leiden dat gelijke percentages verschillende typeringen hebben. Zo ligt landelijk bijvoorbeeld de grenswaarde tussen 'gemiddeld' en 'hoog' op een hoger niveau. Om deze reden krijgt MBO secretariaat met $37 \%$ in Limburg al de typering 'hoog', terwijl HBO commerciele conomic met $39 \%$ in Nederland slechts als 'gemiddeld' word getypeerd. 
Tabel 4.1

Opleidingstypen met relatief het grootste aantal baanopeningen (als percentage van de werkgelegenheid) in Limburg en Nederland tot 2004

Opleidingstype

\begin{tabular}{clll}
$\begin{array}{c}\text { Limburg } \\
\text { baanopeningen } \\
\%\end{array}$ & $\begin{array}{c}\text { Limburg } \\
\text { typering }\end{array}$ & $\begin{array}{c}\text { Nederland } \\
\text { baanopeningen } \\
\%\end{array}$ & $\begin{array}{c}\text { Nederland } \\
\text { typering }\end{array}$ \\
\hline 58 & erg hoog & 45 & hoog \\
52 & erg hoog & 47 & hoog \\
50 & erg hoog & 53 & hoog \\
47 & erg hoog & 41 & hoog \\
41 & hoog & 39 & gemiddeld \\
40 & hoog & 33 & gemiddeld \\
40 & hoog & 38 & gemiddeld \\
39 & hoog & 39 & gemiddeld \\
37 & hoog & 21 & gemiddeld \\
37 & hoog & 41 & hoog \\
& & &
\end{tabular}

Bron: $R O A$

vervangingsvraag of uitbreidingsvraag.

Tabel 4.2 geeft een overzicht van de opleidingstypen waarvoor in Limburg de komende jaren relatief weinig baanopeningen worden verwacht. Voor een aantal, met name techni-

Tabel 4.2

Opleidingstypen met relatief het kleinste aantal baanopeningen (als percentage van de werkgelegenheid) in Limburg en Nederland tot 2004

Opleidingstype

$\begin{array}{cccc}\begin{array}{c}\text { Limburg } \\ \text { baanopeningen }\end{array} & \begin{array}{c}\text { Limburg } \\ \text { typering }\end{array} & \begin{array}{c}\text { Nederland } \\ \text { baanopeningen }\end{array} & \begin{array}{c}\text { Nederland } \\ \text { typering }\end{array} \\ & & \% & \end{array}$

VMBO voertuigentechniek

$\mathrm{MBO}$ bouw

MBO installatietechniek

MBO motorvoertuigentechniek

$\mathrm{MBO}$ openbare orde en veiligheid

MBO elektrotechniek

MBO procestechniek

VMBO landbouw en natuurlijke omgeving WO wiskunde en natuurwetenschappen VMBO transport en logistiek

$\begin{array}{llll}14 & \text { erg laag } & 12 & \text { laag } \\ 15 & \text { erg laag } & 21 & \text { gemiddeld } \\ 15 & \text { erg laag } & 13 & \text { laag } \\ 16 & \text { erg laag } & 18 & \text { gemiddeld } \\ 16 & \text { erg laag } & 17 & \text { gemiddeld } \\ 17 & \text { erg laag } & 16 & \text { gemiddeld } \\ 17 & \text { erg laag } & 23 & \text { gemiddeld } \\ 18 & \text { laag } & 16 & \text { gemiddeld } \\ 18 & \text { laag } & 23 & \text { gemiddeld } \\ 20 & \text { laag } & 22 & \text { gemiddeld }\end{array}$

Bron: $R O A$ 
sche, MBO-opleidingen, zoals bijvoorbeeld $\mathrm{MBO}$ installatietechniek, MBO motorvoertuigentechniek, MBO elektrotechniek en MBO procestechniek is de vraag naar nieuwkomers de komende jaren erg laag.

\section{Arbeidsmarktperspectieven}

De verwachte baanopeningen tonen natuurlijk slechts één kant van de arbeidsmarkt: de vraagzijde. Tegenover de vraag naar arbeidskrachten staat het aanbod van personeel. Het confronteren van de verwachte vraag met het verwachte aanbod, geeft een indicatie van de kansen van schoolverlaters op de toekomstige arbeidsmarkt. We doen dit aan de hand van de Indicator Toekomstige Arbeidsmarktperspectieven (ITA).

De Indicator Toekomstige Arbeidsmarktperspectieven (ITA) geeft voor elk opleidingstype de verhouding weer tussen het arbeidsaanbod met de desbetreffende opleidingsachtergrond en de daar tegenoverstaande vraag. Als het arbeidsaanbod kleiner is dan de vraag, is de ITA kleiner dan 1,00. In dat geval wordt het arbeidsmarktperspectief als goed getypeerd. Schoolverlaters zullen dan naar verwachting betrekkelijk gemakkelijk een baan vinden op een functieniveau en in een richting waarop men, toen de opleiding begon, zou mogen rekenen. Als de waarde van de ITA kleiner is dan 0,85 , dan wordt zelfs gesproken van een zeer goed arbeidsmarktperspectief. Wanneer de ITA daarentegen een waarde heeft tussen de 1,00 en 1,05 dan spreken we van redelijke arbeidsmarktperspectieven. Bij een hogere waarde van de ITA wordt het arbeidsmarktperspectief voor een opleidingstype matig genoemd. Als de ITA zelfs groter is dan 1,15, is er sprake van een slecht arbeidsmarktperspectief.

We beperken ons in deze paragraaf tot de lagere en middelbare opleidingstypen, omdat de hoger opgeleiden een veel grotere (geografische) mobiliteit op de arbeidsmarkt kennen. Daardoor is het moeilijk het regionale aanbod van mensen met een hogere opleidingsachtergrond vast te stellen.

Tabel 4.3 geeft een overzicht van de lagere en middelbare opleidingstypen in Limburg met naar verwachting goede tot zeer goede arbeidsmarktperspectieven. Schoolverlaters van deze opleidingen zullen waarschijnlijk betrekkelijk gemakkelijk een baan vinden op een functieniveau en in een richting die past bij hun opleiding. De verzorgende opleidingen zijn goed vertegenwoordigd in de tabel, met $M B O$ verpleging, VMBO (uiterlijke) verzorging en $M B O$ uiterlijke verzorging. Opmerkelijk zijn ook de zeer goede perspectieven voor $M B O$ landbouw en veeteelt. We zullen in de volgende paragraaf, waar we kort de toekomstige arbeidsmarktperspectieven voor de hogere opleidingstypen in Nederland als geheel bespreken, zien dat de vooruitzichten voor de lagere en middelbare opleidingstypen in Limburg in het algemeen minder gunstig zijn dan voor de hogere opleidingen.

Naast de opleidingen met goede vooruitzichten zijn er ook opleidingstypen op het lagere of middelbare niveau die een minder gunstig toekomstperspectief hebben. Tabel 4.4 geeft een overzicht van de opleidingstypen met een minder gunstig perspectief voor de schoolverlaters. Technische opleidingen, zoals MBO bouw, VMBO bouwtechniek, MBO installatietech- 
Tabel 4.3

Lagere en middelbare opleidingstypen met (zeer) goede perspectieven in Limburg in 2004

\begin{tabular}{lllll} 
Opleidingstype & $\begin{array}{c}\text { Limburg } \\
\text { ITA }\end{array}$ & $\begin{array}{c}\text { Limburg } \\
\text { typering }\end{array}$ & $\begin{array}{c}\text { Nederland } \\
\text { ITA }\end{array}$ & $\begin{array}{c}\text { Nederland } \\
\text { typering }\end{array}$ \\
\hline MBO landbouw en veeteelt & 0,85 & zeer goed & 0,90 & goed \\
VMBO metaal: mechanische techniek & 0,87 & goed & 1,01 & redelijk \\
MBO verpleging & 0,89 & goed & 0,83 & zeer goed \\
VMBO elektrotechniek & 0,90 & goed & 1,05 & redelijk \\
VMBO (uiterlijke) verzorging & 0,90 & goed & 1,04 & redelijk \\
MBO vervoer en logistiek & 0,90 & goed & 0,92 & goed \\
MBO secretariaat & 0,90 & goed & 0,92 & goed \\
MBO uiterlijke verzorging & 0,93 & goed & 0,95 & goed \\
VMBO theorie & 0,94 & goed & 1,06 & matig \\
MBO handel & 0,94 & goed & 0,98 & goed \\
HAVO/VwO & 0,95 & goed & 1,03 & redelijk \\
MBO verzorging & 0,95 & goed & 1,04 & redelijk \\
MBO openbare orde en veiligheid & 0,95 & goed & 0,94 & goed
\end{tabular}

Bron: $R O A$

niek en VMBO voertuigentechniek, zijn in de tabel enigszins oververtegenwoordigd. Bij deze opleidingen zijn de perspectieven voor schoolverlaters in Limburg overigens duidelijk beter dan landelijk.

Tabel 4.4

Lagere en middelbare opleidingstypen met matige tot redelijke perspectieven in Limburg in 2004

\begin{tabular}{lcccc} 
Opleidingstype & $\begin{array}{c}\text { Limburg } \\
\text { ITA }\end{array}$ & $\begin{array}{c}\text { Limburg } \\
\text { typering }\end{array}$ & $\begin{array}{c}\text { Nederland } \\
\text { ITA }\end{array}$ & $\begin{array}{c}\text { Nederland } \\
\text { typering }\end{array}$ \\
\cline { 2 - 5 } MBO beweging en therapie & 1,13 & matig & 1,06 & matig \\
VMBO administratie, handel en mode & 1,11 & matig & 1,25 & slecht \\
MBO installatietechniek & 1,11 & matig & 1,26 & slecht \\
VMBO landbouw en natuurlijke omgeving & 1,07 & matig & 1,13 & matig \\
VMBO bouwtechniek & 1,07 & matig & 1,22 & slecht \\
MBO sociaal-cultureel & 1,07 & matig & 1,04 & redelijk \\
VMBO voertuigentechniek & 1,04 & redelijk & 1,13 & matig \\
MBO bouw & 1,04 & redelijk & 1,12 & matig \\
MBO horeca & 1,03 & redelijk & 0,98 & goed \\
Basisonderwijs & 1,02 & redelijk & 1,12 & matig
\end{tabular}




\subsection{De arbeidsmarkt voor hoger opgeleiden in 2004}

In de vorige paragraaf werden de verwachte perspectieven voor schoolverlaters alleen besproken voor de lagere en middelbare opleidingstypen. De arbeidsmarkt voor de hogere opleidingstypen heeft immers een meer landelijk karakter, vanwege de hogere geografische mobiliteit van de schoolverlaters van deze opleidingen. Daarom bespreken we de vooruitzichten voor het $\mathrm{HBO}$ en het WO aan de hand van het nationale beeld ${ }^{24}$.

Tabel 4.5 geeft een overzicht van de hogere opleidingen met naar verwachting zeer goede perspectieven. Voor de hoger opgeleiden is het beeld bijna onverdeeld gunstig. Er zijn tien opleidingstypen met een zeer goed arbeidsmarktperspectief, waarbij met name de afgestudeerden van de economisch-administratieve en de informatica opleidingen een zeer goed perspectief hebben. Daarnaast zullen ook schoolverlaters van de lerarenopleidingen $H B O$ lerarenopleiding basisonderwijs en $\mathrm{HBO}$ lerarenopleiding economie en maatschappij erg gemakkelijk een baan kunnen krijgen.

De HBO opleidingstypen in tabel 4.5 kunnen grofweg in drie categorieën worden ingedeeld, al naar gelang de voornaamste oorzaken van de zeer goede perspectieven:

- Bij de HBO lerarenopleiding basisonderwijs en de HBO lerarenopleiding economie en maatschappij zorgt de hoge verwachte vervangingsvraag, veroorzaakt door de hoge uitstroom van (oudere) docenten, ervoor dat de vooruitzichten voor toekomstige schoolverlaters gunstig zijn. Bovendien is bij de HBO lerarenopleiding basisonderwijs de arbeidsmarktinstroom van schoolverlaters relatief laag.

- Bij de opleidingen HBO informatica, HBO recht en bestuur en $\mathrm{HBO}$ bibliotheek en documentatie is de hoge uitbreidingsvraag de belangrijkste oorzaak van de zeer goede verwachte arbeidsmarktperspectieven. Deze opleidingen profiteren vooral sterk van de gunstige werkgelegenheidsontwikkeling in de commerciële en niet-commerciële dienstverlening. Voor de opleiding $H B O$ bibliotheek en documentatie geldt bovendien dat de verwachte arbeidsmarktinstroom van schoolverlaters relatief laag is.

- De perspectieven van het opleidingstype HBO accountancy en bedrijfseconomie zijn gunstig ondanks het feit dat deze studie populair is en daardoor veel studenten trekt. Het goede perspectief van deze opleiding is voor het gevolg van het feit dat deze opleiding sterk profiteert van de tekorten bij de economische opleidingen op WO-niveau, zoals WO accountancy en belastingen en WO econom(etr)ie.

Met name bij de opleiding WO accountancy en belastingen zijn de arbeidsmarktperspectieven zeer goed. Evenals bij de opleidingen WO informatica en bestuurlijke informatie, WO cconom(etr)ie en WO bedrijfskunde, zijn de zeer goede arbeidsmarktperspectieven vooral het gevolg van een erg hoge uitbreidingsvraag. Mensen met deze opleidingen vinden voornamelijk emplooi in de snel groeiende zakelijke dienstverlening. Aan deze groeiende vraag

24 De in deze paragraaf gepresenteerde uitkomsten zijn ontleend aan de ROA-publicatie De arbeidsmarkt naar opleiding on beroep tor 2004, ROA-R-1999/8, Maastricht, 1999. 
Tabel 4.5

Hogere opleidingstypen met zeer goede perspectieven in Nederland in 2004

Opleidingstype

WO accountancy en belastingen

WO informatica en bestuurlijke informatiekunde

$\mathrm{HBO}$ informatica

$\mathrm{HBO}$ lerarenopleiding basisonderwijs

$\mathrm{HBO}$ lerarenopleiding economie en maatschappij

$\mathrm{HBO}$ recht en bestuur

WO econom(etr)ie

$\mathrm{HBO}$ bibliotheek en documentatie

$\mathrm{HBO}$ accountancy en bedrijfseconomie

WO bedrijfskunde
ITA

typering

zeer goed

zeer goed

zeer goed

zeer goed

zeer goed

zeer goed

zeer goed

zeer goed

zeer goed

zeer goed

Bron: De Arbeidsmarkt Naar Opleiding en Beroep tor 2004, ROA-R-1999/8

vanuit de arbeidsmarkt kan naar verwachting de komende jaren niet worden voldaan, ondanks de populariteit van deze opleidingen en de daaruit resulterende hoge toekomstige instroom.

\subsection{Kansen op de arbeidsmarkt: een typologie}

In deze paragraaf wordt een typologie gegeven van de arbeidsmarktkansen voor schoolverlaters van de onderscheiden opleidingstypen op VMBO- en MBO-niveau op de Limburgse arbeidsmarkt. Dit doen we aan de hand van een drietal aspecten:

- het toekomstig arbeidsmarktperspectief

- de conjunctuurgevoeligheid van de werkgelegenheid

- de uitwijkmogelijkheden op de arbeidsmarkt.

Het toekomstig arbeidsmarktperspectief is reeds uitvoerig aan de orde geweest in de voorgaande paragraaf. Dit arbeidsmarktperspectief wordt voor een belangrijk deel bepaald door de verwachte economische en demografische ontwikkelingen. Een goed perspectief kan het gevolg zijn van een structureel sterke positie van het betreffende opleidingstype op de arbeidsmarkt. Het kan echter ook voor een belangrijk deel conjunctureel van aard zijn. Zo kan een relatief gunstige conjuncturele ontwikkeling een structureel zwakke arbeidsmarkıpositie tijdelijk compenseren. Wanneer de keuze voor een conjunctuurgevoelig opleidingstype gebaseerd is op een goed perspectief, bestaat het risico dat de kansen op de arbeidsmarkt op het moment dat het diploma behaald wordt slecht zijn, omdat de economische situatie door een plotselinge conjuncturele dip plotseling is verslechterd. Bovendien is er in dat geval sprake van een onzekere werkgelegenheidssituatie op de langere termijn, vanwege de grotere kans op toekomstig baanverlies als er op een gegeven moment sprake is van een laagconjunctuur. De conjunctuurgevoeligheid van de werkgelegenheid is derhalve een risico-indicator, waarmee een belangrijk facet wordt belicht van de structurele arbeidsmarktpositie van een opleidingstype. 
De mate waarin schoolverlaters afhankelijk zijn van de werkgelegenheidsperspectieven in een beperkt aantal beroepsgroepen is ook een risico-factor. Dit risico is vooral groot bij specialistische opleidingen die specifiek gericht zijn op functies in een bepaalde vakdeelmarkt. Degenen die een opleiding hebben gevolgd waarmee men in diverse beroepsgroepen emplooi kan vinden, kunnen daarentegen, wanneer het werkgelegenheidsperspectief in een bepaalde beroepsgroep minder gunstig is, betrekkelijk gemakkelijk uitwijken naar beroepen waarvoor de werkgelegenheidsontwikkeling op dat moment gunstiger is. Er is als het ware sprake van een zekere risico-spreiding. Bovendien zijn degenen die voor deze opleidingen hebben gekozen flexibeler op de arbeidsmarkt.

Het volgen van een brede opleiding is overigens niet in alle gevallen positief. Wanneer er sprake is van veel uitwijkmogelijkheden impliceert dit immers ook dat de schoolverlaters meer concurrentie ondervinden van andere opleidingstypen. Bovendien kan een verbreding van de opleiding ten koste gaan van de specialisatie, waardoor de directe inzetbaarheid van de schoolverlaters geringer wordt. Wanneer de concurrentieslag met andere opleidingen daardoor verloren wordt, kan dat in sommige gevallen zelfs betekenen dat de schoolverlaters in een breed scala van onaantrekkelijke beroepen met slechte arbeidsvoorwaarden terechtkomen. Men spreekt in dit verband wel van de secundaire arbeidsmarkt.

Figuur 4.1 geeft een typologie van de arbeidsmarktkansen voor schoolverlaters van de onderscheiden opleidingstypen op VMBO- en MBO-niveau op de Limburgse arbeidsmarkt. De figuur deelt de opleidingstypen in op basis van de arbeidsmarktperspectieven en de combinatie van de beide risico-factoren: de conjunctuurgevoeligheid en de uitwijkmogelijkheden op de arbeidsmarkt, c.q. de breedte van de inzetbaarheid ${ }^{25}$.

Wanneer een goed arbeidsmarktperspectief gepaard gaat met een laag arbeidsmarktrisico dat wil zeggen een lage tot gemiddelde conjunctuurgevoeligheid van de werkgelegenheid en gemiddelde tot grote uitwijkmogelijkhederi - dan geeft het betreffende opleidingstype schoolverlaters een sterke positie op de arbeidsmarkt. Op de Limburgse arbeidsmarkt geldt dit met name voor de opleidingstypen in het kwadrant rechtsboven in figuur 4.1.

Bij sommige van deze opleidingen gaat het goede perspectief gepaard met een lage conjunctuurgevoeligheid. Dit zijn VMBO (uiterlijke) verzorging en $M B O$ milieu en groene ruimte. De kansen op werk voor nieuwkomers met één van deze opleidingsachtergronden zijn betrekkelijk ongevoelig voor conjuncturele fluctuaties. Bovendien zal later in de loopbaan, wanneer de conjunctuur op een gegeven moment verslechtert, de kans relatief klein zijn dat men zijn baan verliest. Verder zijn er opleidingstypen waarbij de sterke positie met name het gevolg is van de brede inzetbaarheid. Opleidingstypen met (erg) veel uitwijkmogelijkheden zijn de opleidingen $V M B O$ theorie en $H A V O / V W O$. Ook MBO secretariaat en $M B O$ administratie zijn opleidingstypen die goede arbeidsmarktperspectieven combineren met een brede inzetbaarheid.

25 Een volledig overzicht van het arbeidsmarkiperspectief, de conjunctuurgevoeligheid en de uitwijkmogelijkheden naar opleidingstype, waarop deze paragraaf is gebaseerd, wordt gegeven in de Statistische Bijlage van dis rapport. (Vooralsnog zijn, in het licht van de betrouwbaarheid en de beschikbaarheid van de vereiste regionale data, de indicatoren voor de conjunctuurgevoeligheid van de werkgelegenheid en de uitwijkmogelijkheden gebaseerd op landelijke cijfers.) 
Figuur 4.1

Arbeidsmarktpositie op basis van het arbeidsmarktperspectief, de conjunctuurgevoeligheid van de werkgelegenheid en de uitwijkmogelijkheden

Matig arbeidsmarktperspectief
Breed inzetbaar (b)
Ongevoelig voor conjunctuur (o)
VMBO landbouw en natuurlijke omgeving (o)
VMBO consumptief en levensmiddelentechniek
(b,o)
VMBO administratie, handel en mode (b)
VMBO beveiliging (b,o)
MBO laboratorium (b,o)
MBO sociaal-cultureel ( $b, 0)$
Beperkt inzetbaar (b)
Conjunctuurgevoelig ( $g$ )
VMBO bouwtechniek ( $g$ )
MBO installatietechniek (b, $g$ )
MBO operationele techniek ( $g$ )
MBO dokters-, tandarts- en dierenarts-
MBO beweging en therapie (b)

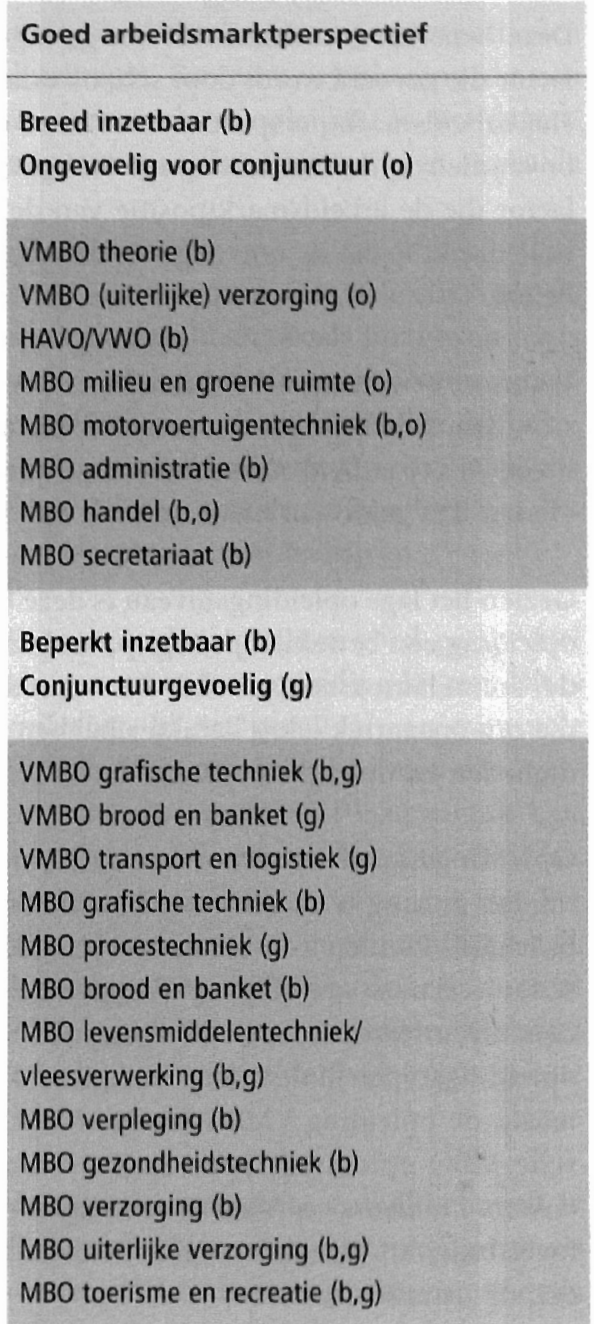

Bron: ROA

Wanneer daarentegen een goed arbeidsmarktperspectief gepaard gaat met een hoog risico dan is weliswaar de kans op een passende baan voor schoolverlaters met een dergelijke opleidingsachtergrond groot, maar kan een plotselinge verslechtering van de arbeidsmarktsituatie een sterk negatief effect hebben op de arbeidsmarktpositie. Dit geldı met name voor de opleidingstypen rechtsonder in figuur 4.1. Het gaat hier voor een groot deel om verplegende en verzorgende opleidingen en daarnaast ook om een aantal technische opleidingen. De arbeidsmarktkansen voor de schoolverlaters van deze technische opleidingen zijn zeer gevoelig voor de werkgelegenheidsontwikkelingen in de conjunctuurgevoelige industriële bedrijfssectoren en de bouw. Een verdere conjuncturele achteruitgang kan daarmee het perspectief aanzienlijk verslechteren. De schoolverlaters zullen dan de nadelige effecten van 
hun beperkte inzetbaarheid merken. Voor deze specialistische, technische opleidingstypen vormt de beperkte inzetbaarheid buiten het eigen beroependomein een risicoverhogende factor, waar terdege rekening mee gehouden dient te worden.

Deze beperkte inzetbaarheid, het geringe aantal uitwijkmogelijkheden is ook een risicofactor die gevoeld wordt door schoolverlaters van de verplegende en verzorgende beroepen. Het arbeidsmarktperspectief voor deze opleidingstypen is echter goed tot zeer goed en bovendien is de conjunctuurgevoeligheid van de werkgelegenheid gering. Een tweede factor die de arbeidsmarktpositie van de schoolverlaters van deze opleidingstypen kwetsbaar maakt is dat de omvang van de vraag in aanzienlijke mate afhangt van het overheidsbeleid.

Wanneer een matig arbeidsmarktperspectiel gepaard gaat met een gering arbeidsmarktrisico, dan is de kans op een passende baan naar verwachting weliswaar klein, maar biedt de brede inzetbaarheid misschien mogelijkheden om elders op de arbeidsmarkt een plek te vinden. Dit geldt met name voor de opleidingstypen linksboven in de figuur.

Gezien het lage opleidingsniveau is deze brede inzetbaarheid voor degenen met een VMBOopleiding een betrekkelijk begrip. Vaak zullen schoolverlaters terechtkomen in functies op de 'secundaire arbeidsmarkt'. Dit secundaire arbeidsmarktsegment kent met name banen die een onaantrekkelijk karakter hebben als gevolg van bijvoorbeeld zware arbeidsomstandigheden en tijdelijke contracten.

Opleidingstypen waarvoor het toekomstige arbeidsmarktperspectief naar verwachting minder gunstig is en waarvoor bovendien de risico-indicatoren wijzen op een grote kwetsbaarheid, kennen een structureel zwakke positie op de arbeidsmarkt. De kans dat de schoolverlaters van deze opleidingen een passende baan vinden is klein. Bovendien is de concurrentiepositie op andere segmenten van de arbeidsmarkt zwak. Dit geldt voor de opleidingstypen linksonder in figuur 4.1. Met name de hoge conjunctuurgevoeligheid maakt de opleiding VMBO bouwtechniek extra kwetsbaar. Hetzelfde geldt voor de technische $\mathrm{MBO}-$ opleidingstypen in dit kwadrant. Schoolverlaters van de opleidingen $M B O$ dokters-, tandarts- en dierenartsassistent en MBO apothekersassistent zijn binnen het MBO kwetsbaar vanwege de matige arbeidsmarktperspectieven en de geringe uitwijkmogelijkheden op de arbeidsmarkt.

\subsection{Aandachtspunten voor het onderwijsbeleid}

Paragraal 2.5 heeft laten zien dat voor schoolverlaters de initiële opleidingskeuze voor een groot deel bepalend is voor hun arbeidsmarktpositie. Ook voor het verdere loopbaanperspectief speelt de initiële opleidingsachtergrond een belangrijke rol. In het onderwijsbeleid wordt op dit punt met name gekeken naar de zogenaamde macrodoelmatigheid van de opleidingscapaciteit in een regio. Vanuit het oogpunt van de macrodoelmatigheid van het onderwijs is het wenselijk de instroom in opleidingen met goede of zeer goede arbeidsmarktperspectieven te bevorderen. Nieuw aanbod van opleidingen zal echter met name zin hebben wanneer er leerlingen worden aangetrokken die anders een opleiding zouden kiezen met duidelijk slechtere perspectieven. Een goede regionale spreiding van de opleidingen is op dit punt van groot belang. Immers, de keuze voor opleidingen met minder gunstige 
perspectieven kan het gevolg zijn van een te grote reisafstand naar een school waar een meer perspectiefrijke opleiding gevolgd zou kunnen worden die eveneens aansluit op de belangstelling en de capaciteiten van de desbetreffende leerling.

Een andere oorzaak voor de keuze voor een opleiding met minder gunstige perspectieven kan liggen in de capaciteiten en interesses van de leerlingen. Een nieuwe opleiding, die een 'beroepsbegeleidende leerweg' biedt aan leerlingen waarvoor een opleiding in het dagonderwijs minder geschikt is, kan zeer waardevol zijn om meer leerlingen in een bepaalde vakrichting op te leiden.

De omvang van de verwachte instroom op de arbeidsmarkt vormt een indicatie voor de mogelijkheden die een vergroting van de opleidingscapaciteit biedt. Zoals hierboven reeds werd opgemerkt, dient een capaciteitsvergroting ter vergroting van de macrodoelmatigheid gepaard te gaan met het aantrekken van de juiste doelgroep en dient er voldoende 'infrastructuur' in de regio aanwezig te zijn om de toegenomen leerlingenstroom een adequate voorbereiding op de arbeidsmarkt te kunnen bieden. Hierbij gaat het niet alleen om het onderwijs zelf, maar bijvoorbeeld ook om het aantal leerplaatsen bij bedrijven.

Wanneer de verwachte arbeidsmarktinstroom bij een opleiding met een goed perspectief relatief klein is, dan is het wenselijk dat meer leerlingen voor deze opleiding kiezen. Dit is bijvoorbeeld het geval bij de opleiding MBO verpleging. In dat geval zal een eventuele vergroting van de opleidingscapaciteit waarschijnlijk snel kunnen leiden tot een daadwerkelijke vergroting van de instroom, omdat de instroom op een relatief laag niveau ligt. Wanneer de verwachte arbeidsmarktinstroom daarentegen reeds relatief hoog is, vindt het goede perspectief vooral zijn oorsprong in de grote vraag naar nieuwkomers met het betreffende opleidingstype. De opleiding is dan reeds relatief populair in verhouding tot de 'omvang' van de markt voor deze opleiding in Limburg. Dit impliceert dat een verdere vergroting van de instroom waarschijnlijk aanzienlijke inspanningen zal vragen, zoals het verder vergroten van het aantal leerplaatsen bij bedrijven en het aanboren van geheel nieuwe doelgroepen van potentiële leerlingen.

Naast het arbeidsmarktperspectief, dat gebaseerd is op de verwachte ontwikkelingen in vraag en aanbod, kan het onderwijsbeleid ook de structurele positie van opleidingen als richtlijn nemen. De twee in paragraaf 4.4 genoemde risico-indicatoren zijn op dit punt van belang: de conjunctuurgevoeligheid van de werkgelegenheid en de uitwijkmogelijkheden naar verschillende beroepsgroepen. Bepaalde opleidingen combineren een hoge mate van conjunctuurgevoeligheid met beperkte uitwijkmogelijkheden. Veranderingen in het curriculum, waardoor de opleiding wordt verbreed en waardoor toegang wordt verkregen tot een breder beroependomein, kunnen deze kwetsbaarheid van de schoolverlaters op de arbeidsmarkt verminderen.

Omgekeerd kunnen ontwikkelingen aan de vraagkant van de arbeidsmarkt leiden tot een behoefte aan personeel met meer specifieke kennis en vaardigheden. Hierdoor kan het wenselijk zijn een meer specialistische opleiding te starten. Hierbij dient echter wel overwogen te worden in hoeverre de vraag naar deze vakspecialisten stabiel is. Immers, de voordelen van het specialisme moeten opwegen tegen de rísico's die de schoolverlaters met een dergelijke specialisatie lopen. 
De volgende opleidingstypen hebben een structureel sterke positie op de Limburgse arbeidsmarkt: VMBO (uiterlijke) verzorging, $M B O$ milieu en groene ruimte, MBO motorvoertuigentechniek, MBO handel, MBO administratie en MBO secretariaat. Vanwege de over het algemeen relatief lage verwachte arbeidsmarktinstroom in de opleidingen met een goed perspectief, kan een vergroting van de populariteit van deze opleidingen - gekoppeld aan een eventuele uitbreiding van de capaciteit - een zeer effectief middel zijn om de macrodoelmatigheid van het onderwijs in Limburg te vergroten. Uitzonderingen vormen de 'groene' opleidingen en de laboratoriumopleiding die gekenmerkt worden door een relatief grote arbeidsmarktinstroom van schoolverlaters. Indien de conjunctuurgevoeligheid van de werkgelegenheid voor een bepaald opleidingstype groot is, dienen de conjuncturele ontwikkelingen hierbij echter zorgvuldig in het oog gehouden te worden, gezien de gevoeligheid van de vraag naar met name schoolverlaters met een technische achtergrond voor schommelingen in de conjunctuur.

Een bijzondere positie nemen de verzorgende en medische opleidingen op MBO-niveau in Het arbeidsmarktperspectief is voor veel van deze opleidingstypen goed tot zeer goed. Bovendien is de conjunctuurgevoeligheid van de werkgelegenheid laag. Gezien de relatief lage verwachte instroom kan een vergroting van de populariteit van deze opleidingen de macrodoelmatigheid van het onderwijs in Limburg bevorderen. Twee factoren maken de arbeidsmarktpositie van de schoolverlaters van deze opleidingstypen echter kwetsbaar. In de eerste plaats is de omvang van de vraag in aanzienlijke mate afhankelijk van het overheidsbeleid. In de tweede plaats zijn de arbeidskrachten met een medische of verzorgende opleidingsachtergrond beperkt inzetbaar; de uitwijkmogelijkheden op de arbeidsmarkt zijn over het algemeen gering.

Het opleidingstype VMBO administratie, handel en textiel kent een matig perspectief. De brede inzetbaarheid van de schoolverlaters van deze opleiding biedt echter misschien mogelijkheden elders op de arbeidsmarkt een plek te vinden. Velen zullen dan echter vaak terecht komen op de secundaire arbeidsmarkt. Een structureel zwakke positie op de arbeidsmarkt hebben de opleidingstypen VMBO bouwtechniek, MBO installatietechniek en MBO operationele techniek.

De macrodoelmatigheid van het beroepsonderwijs is het meest gebaat bij een adequaat aanbod van leerwegen die VMBO schoolverlaters in staat stellen een kwalificatie op MBOniveau te behalen. Dit geldt het sterkst voor de technische, de economisch-administratieve en de horeca-opleidingen. Vanzelfsprekend geldt dit ook voor de opleidingen die ongeschoolden met slechts Basisonderwijs, VMBO theorie en HAVO/VWO'ers in staat stellen met succes een beroepsopleiding te volgen met goede arbeidsmarktperspectieven en geringe arbeidsmarkırisico’s. 


\section{Uitgelicht: МBO verpleging}

Aan de hand van de verwachte ontwikkelingen aan de vraag- en aanbodzijde van de arbeidsmarkt kan een indicatie gegeven worden van de toekomstige arbeidsmarktperspectieven op de middellange termijn voor nieuwkomers op de arbeidsmarkt. Dit arbeidsmarktperspectief geeft aan wat de mogelijkheden zijn voor nieuwkomers om een baan te vinden die op grond van de opleidingsachtergrond als passend kan worden beschouwd. Aan de vraagzijde wordt een onderscheid gemaakt tussen de uitbreidings- en vervangingsvraag. Tezamen vormen deze het aantal baanopeningen voor nieuwkomers. Voor de opleiding MBO verpleging wordt in de periode 1999-2004 in Limburg een uitbreidingsvraag van $4 \%$ van de huidige werkgelegenheid voor dit opleidingstype verwacht (tabel 4.5 van de Statistische Bijlage). De vervangingsvraag voor mensen met deze opleidingsachtergrond zal gedurende de periode 1999-2004 naar verwachting $18 \%$ bedragen (tabel 4.6). Hieruit resulteert in vijf jaar tijd een percentage baanopeningen van $22 \%$ (tabel 4.7 ).

Tegenover de verwachte ontwikkelingen aan de vraagzijde staan de stromen aan de aanbodzijde van de arbeidsmarkt, i.c. de arbeidsmarktinstroom. Deze bedraagt over de periode 1999-2004 slechts 7\% (tabel 4.8). Het arbeidsaanbod voor dit opleidingstype blijft daarmee sterk achter bij de vraag. Dit betekent dat voor degenen die vanuit de opleiding $M B O$ verpleging op de arbeidsmarkt instromen het arbeidsmarktperspectief goed is. Dit blijkt ook uit de waarde van de Indicator Toekomstige Arbeidsmarktperspectieven van 0,88 (tabel 4.10).

Het arbeidsmarktperspectief voor een opleiding wordt voor een belangrijk deel bepaald door de verwachte economische ontwikkeling. Het goede perspectief voor een opleiding kan daarbij het gevolg zijn van een structureel sterke positie op de arbeidsmarkt. Het kan echter ook voornamelijk conjunctureel van aard zijn. Bij de opleiding MBO verpleging is de conjunctuurgevoeligheid van de werkgelegenheid echter laag (zie tabel 4.10).

De risico's op de arbeidsmarkt beperken zich niet tot de conjuncturele fluctuaties in de werkgelegenheid. Ook de mate waarin schoolverlaters afhankelijk zijn van de werkgelegenheids-perspectieven in een beperkt aantal beroepsgroepen is een belangrijke risicofactor. Dit wordt uitgedrukt in de spreidingsindex, die voor de opleiding $M B O$ verpleging 3,17 bedraagt (zie tabel 4.10). Hiermee wordt aangegeven dat voor deze opleiding de uitwijkmogelijkheden naar andere beroepsgroepen zeer gering zijn. Veranderingen in het curriculum, waardoor de opleiding wordt verbreed en daardoor toegang verschaft tot een breder beroependomein, kan deze kwetsbaarheid verminderen. Wel dient bedacht te worden dat een dergelijke verbreding niet slechts voordelen biedt. Wanneer er sprake is van veel uitwijkmogelijkheden impliceert dit immers ook dat de schoolverlaters meer concurrentie ondervinden van andere opleidingstypen. Bovendien kan het ten koste gaan van de specialisatie, waardoor de directe inzetbaarheid van de schoolverlaters geringer wordt. De goede arbeidsmarktperspectieven zijn dan vrij ongevoelig voor de conjuncturele ontwikkeling. 
DE LMRURGSE ARBEIDSMARKT 1999-2004 


\section{Regionale en sectorale perspectieven}

Regio

In Noord-en Midden-Limburg zijn met name de sectoren landbouw en visserij en metaal en elektrotechniek sterk vertegenwoordigd. Zuid-Limburg kenmerkt zich daarentegen vooral door een grotere concentratie van de werkgelegenheid in de chemische industrie en in de dienstensectoren. Dit weerspiegelt zich in de regionale beroepen-en opleidingenstructuur. In Noord-en MiddenLimburg is er vooral veel werkgelegenheid in de lagere en middelbare agrarische beroepen. In Zuid-Limburg is er verhoudingsgewijs veel werkgelegenheid in de economisch en technisch georiënteerde beroepen. Gelet op de structuur van de werkgelegenheid zal de grote krapte in de sectoren horeca, reparatie en zakelijke dienstverlening en kwartaire diensten zich met name in Zuid-Limburg sterk doen gelden. De grote krapte in de lagere agrarische beroepen concentreert zich daarentegen in de regio Noord-en Midden-Limburg. Zuid-Limburg wordt sterker geconfronteerd met een grote krapte in de beroepssegmenten lagere verzorgende beroepen en lagere administratieve, commerciele beroepen. De krapte in de opleidingssectoren HBO Economie en HBO Sociaal-Cultureel is het sterkst in Zuid-Limburg. Er zijn ook regionale verschillen waar te nemen in de aantallen niet-werkende werkzoekenden. Daarbij is het beeld voor Noord-en Midden-Limburg iets gunstiger dan voor Zuid-Limburg. Bovendien is in Noord-en MiddenLimburg een groter deel van de niet-werkende werkzoekenden direct bemiddelbaar, terwijl het percentage langdurig werkzoekenden in Noord-en Midden-Limburg 3\%-punten lager ligt dan in Zuid-Limburg. Met name de rayons Parkstad Limburg en Maastricht-Mergelland hebben een relatief hoge werkloosheid.

\section{Horeca, toerisme en recreatie}

De horeca wordt geconfronteerd met grote knelpunten op de Limburgse arbeidsmarkt. In vergelijking met de grote krapte in 1998 is de situatie vanuit werkgeversoptiek in 1999 enigszins verbeterd. Het percentage langdurig openstaande vacatures is het afgelopen jaar met 6\%-punt gedaald tot $32 \%$. Binnen de horeca zijn de problemen het grootst in de keuken (afwashulpen, keukenassistent, kok), maar ook in de bediening is sprake van grote knelpunten in de personeelsvoorziening (medewerkers bediening, gastheren en -vrouwen, leidinggevenden). Voor de subsector toerisme en recreatie zijn de wervingsproblemen het grootst waar het gaat om koks ch medewerkers bediening. De problemen die in de sector horeca, toerisme en recreatie spelen hebben ook een kwalitatieve achtergrond. De houding, flexibiliteit en sociale vaardigheden van het personeel worden in de sector dan ook steeds belangrijker.

\section{Overheid}

De meest voorkomende langdurig openstaande vacatures in de sector overheid hebben betrekking op technici, ICT-medewerkers, secretariaatsmedewerkers en financieel-administratieve medewerkers. De overheid in enge zin heeft met name behoefte aan instroom van jongeren en tijdelijke krachten. Voor het onderwijs spitsen de problemen zich toe op het werven van docenten voor het primair en voortgezet onderwijs. Voor de overheid in enge zin is het bovendien moeilijk verkeersplanologen, accountmanagers, wijkcoördinatoren, politiesurveillanten, agenten en mensen voor de jeugdzorg te vinden. De verwachte knelpunten in de personeelsvoorziening in de sector overheid en onderwijs zijn ook de komende jaren zeer groot. Deze knelpunten komen voornamelijk voort uit een grote vervangingsvraag, die het gevolg is van de vergrijzing binnen de sector: Voor zowel de sector horeca, toerisme en recreatic als voor de overheid kunnen de aclu- 
ele en verwachte knelpunten op een aantal manieren worden verlicht: verbetering van de aansluiting onderwijs-arbeidsmarkt, het aanboren van alternatieve wervingskanalen en -categorieèn en ten slotte het inzetten van personeelsbeleid.

\subsection{Inleiding}

Uit voorgaande hoofdstukken is naar voren gekomen dat de Limburgse arbeidsmarkt nu en in de toekomst gekenmerkt wordt door een tekort aan geschikt personeel op een groot aantal arbeidsmarktsegmenten. In dit hoofdstuk worden de verwachte knelpunten naar regio en sector verbijzonderd. In paragraaf 5.2 wordt eerst, verbijzonderd naar de twee regio's Noord- en Midden-Limburg en Zuid-Limburg, een beeld geschetst van de structuur van de werkgelegenheid, de samenstelling van het aanbod van niet-werkende werkzoekenden alsmede van de voornaamste huidige en toekomstige knelpunten op de arbeidsmarkt. Daarna zullen de vijf Limburgse rayons op basis van een aantal structuurkenmerken worden getypeerd. In paragraaf 5.3 wordt aansluitend ingegaan op de achtergronden van de tekorten aan geschikt personeel in de twee sectoren die dit jaar door het ETIL nader onder de loep zijn genomen: de sector horeca, toerisme en recreatie en de sector overheid. Inzicht in de oorzaken van de knelpunten in de personeelsvoorziening kan het startpunt vormen voor het vinden van mogelijke oplossingen van het probleem: Ook deze mogelijke oplossingen komen in paragraal 5.3 aan de orde.

\subsection{Een verbijzondering naar regio}

\section{Structuur van de werkgelegenheid}

In de tabellen 1.3 en 1.4 van de Statistische Bijlage wordt een overzicht gegeven van het aantal werkenden per bedrijfssector in de Limburgse regio's. Daaruit blijkt dat met name de sectoren landbouw en visserij en metaal en elektrotechniek in Noord- en Midden-Limburg sterk vertegenwoordigd zijn. Zuid-Limburg kenmerkt zich, naast het relatief grote werkgelegenheidsaandeel van de chemische industrie, vooral door een grotere concentratie van de werkgelegenheid in de dienstensectoren. Dit geld t met name voor de sectoren bank-en verzekeringswezen, horeca, reparatie en zakelijke dienstverlening, kwartaire diensten en overheid en onderwijs. Voor wat betreft de horeca ligt het accent daarbij op de logiesverstrekkende bedrijven ${ }^{20}$. Binnen de sector overheid en onderwijs is in Zuid-Limburg vooral het aantal werkenden in het hoger onderwijs hoog ${ }^{27}$.

De werkgelegenheid naar sector heeft vanzelfsprekend ook consequenties voor de beroepen- en opleidingenstructuur van de werkgelegenheid. De beroepenstructuur komt naar voren uit de tabellen 1.11 en 1.12 van de Statistische Bijlage. Deze geven een indicatie van de over- dan wel ondervertegenwoordiging van een beroepssegment in een regio. Vooral de agrarische beroepen zijn in Noord- en Midden-Limburg sterk vertegenwoordigd. Dit geldt met name voor de lagere en de middelbare agrarische beroepen: agrarische arbeiders, agrarische vakkrachten en agrarische bedrijfshoofden. In Zuid-Limburg is er verhoudingsgewijs

26. Zic Sectorrapportage horca, toerisme \& recreatic, ETIL, Maastricht, 1999

27 Zie Sectorrapportage overheid, ETIL. Maastricht, 1999. 
veel werkgelegenheid in een viertal beroepssegmenten: de lagere administratieve, commerciële beroepen, de lagere verzorgende beroepen, de middelbare technische beroepen en de middelbare juridische, bestuurlijke beveiligingsberoepen.

Het beeld voor de opleidingssectoren is hiermee vergelijkbaar, zoals blijkt uit de tabellen 1.20 en 1.21 van de Statistische Bijlage. In Noord- en Midden-Limburg zijn relatief veel mensen werkzaam met een opleidingsachtergrond VMBO Landbouw en natuurlijke omgeving en MBO Landbouw en natuurlijke omgeving. In Zuid-Limburg daarentegen is er sprake van oververtegenwoordiging van mensen met een opleiding Basisonderwijs, VMBO Economie, HAVO/VWO, MBO Economie, HBO Economie en HBO Sociaal-Cultureel.

\section{Regionale verbijzondering niet-werkende werkzoekenden}

In tabel 1.2 werden de ontwikkelingen geschetst aan de aanbodzijde van de Limburgse arbeidsmarkt. Daaruit bleek dat het aantal niet-werkende werkzoekenden tussen februari 1997 en april 1999 aanzienlijk is gedaald. Dat gold eveneens voor de percentages langdurig werkzoekenden en de niet-werkende werkzoekenden in fase 1. In deze paragraaf wordt bekeken of de regio's Noord- en Midden-Limburg en Zuid-Limburg in even sterke mate van deze gunstige ontwikkeling hebben geprofiteerd. Tabel 5.1 geeft een beeld van de regionale aanbodsituatie. Daaruit blijkt dat 36\% van het totaal aantal niet-werkende werkzoekenden woonachtig is in Noord- en Midden-Limburg, tegenover 64\% in Zuid-Limburg. Omdat de bevolkingsverhouding tussen Noord- en Midden-Limburg en Zuid-Limburg ongeveer $43 \%$ tegenover $57 \%$ bedraagt, is de verdeling van het totale aantal niet-werkende werkzoekenden over de beide regio's min of meer gelijkmatig, met een iets gunstiger beeld voor Noorden Midden-Limburg. Bovendien is in Noord- en Midden-Limburg een groter deel van de niet-werkende werkzoekenden direct bemiddelbaar, terwijl het percentage langdurig werkzoekenden in Noord- en Midden-Limburg 3\%-punten lager ligt dan in Zuid-Limburg. Daar staat tegenover dat in Noord- en Midden-Limburg duidelijk meer werkzoekenden in fase 4 zijn ingedeeld. De verdeling van de niet-werkende werkzoekenden over beroepssegmenten en opleidingssectoren laat tussen de beide regio's weinig verschillen zien.

\section{Tabel 5.1}

Niet-werkende werkzoekenden (exclusief geen beroep op dienstverlening) in Noord- en Midden-Limburg, Zuid-Limburg en Limburg (totaal), april 1999

\begin{tabular}{|c|c|c|c|c|c|c|}
\hline & \multicolumn{2}{|c|}{ Noord- en Midden-Limburg } & \multicolumn{2}{|c|}{ Zuid-Limburg } & \multicolumn{2}{|c|}{ Limburg (totaal) } \\
\hline & aantal & $\%$ & aantal & $\%$ & aantal & $\%$ \\
\hline Niet-werkende werkzoekenden & 13.500 & 36 & 23.800 & 64 & 37.300 & 100 \\
\hline w.v. langdurig werkzoekend & 7.300 & 54 & 13.700 & 57 & 20.900 & 56 \\
\hline w.v. fase 1 & 3.000 & 22 & 4.200 & 18 & 7.100 & 19 \\
\hline w.v. fase 2 en 3 & 5.400 & 40 & 12.100 & 51 & 17.500 & 47 \\
\hline w.v. fase 4 & 5.100 & 38 & 7.500 & 31 & 12.700 & 34 \\
\hline
\end{tabular}

Bron: Arbeidsvoorziening/ROA 


\section{Regionale arbeidsmarktkrapte in 1999}

Gelet op de verschillen in de structuur van de werkgelegenheid in de Limburgse regio's zal de arbeidsmarktkrapte in bepaalde bedrijfssectoren, beroepssegmenten of opleidingssectoren zich in de ene regio sterker doen gelden dan in de andere. Dit betekent dat de grote krapte in de sectoren horeca, reparatie en zakelijke dienstverlening en kwartaire diensten (tabel 2.9 van het hoofdrapport) zich met name in Zuid-Limburg sterk zal doen gelden. De grote krapte in de lagere agrarische beroepen en in de middelbare technische beroepen (tabel 2.10) concentreert zich daarentegen in de regio Noord- en Midden-Limburg. Zuid-Limburg wordt bovendien sterker geconfronteerd met een grote krapte in de beroepssegmenten lagere verzorgende beroepen en lagere administratieve, commerciële beroepen. De krapte in de opleidingssectoren HBO Economie en HBO Sociaal-Cultureel (tabel 2.11) is het sterkst in Zuid-Limburg.

\section{Verwachte regionale knelpunten in de personeelsvoorziening in $\mathbf{2 0 0 0}$}

De naar verwachting grote knelpunten in de personeelsvoorziening voor de agrarische arbeiders (tabel 3.6 van de Statistische Bijlage) concentreren zich waarschijnlijk in Noorden Midden-Limburg.

Een voorbeeld van een beroepssegment dat in Zuid-Limburg oververtegenwoordigd is, zijn de lagere administratieve, commerciële beroepen. Hieronder vallen onder andere de receptionisten en administratieve employés. De voor deze beroepsgroep verwachte zeer grote knelpunten in de personeelsvoorziening in 2000 zullen zich derhalve naar verwachting concentreren in Zuid-Limburg. Hetzelfde geldt bijvoorbeeld voor de hulpkrachten horeca en verzorging, de café- en snackbarhouders en een groot aantal middelbaar technische beroepen. Voor het merendeel van de overige beroepsgroepen waarvoor in 2000 knelpunten in de personeelsvoorziening worden verwacht, zal de problematiek zich niet concentreren in een bepaalde regio, maar overal in de provincie even sterk gevoeld worden.

\section{Verwachte regionale knelpunten in de personeelsvoorziening in 2004}

Tabel 4.9 van de Statistische Bijlage laat zien dat de verwachte knelpunten in de personeelsvoorziening op middellange termijn naar verwachting groot zullen zijn voor mensen met een opleidingsachtergrond MBO landbouw en veeteelt. De grotere vraag naar middelbaar opgeleiden met deze opleidingsachtergrond weerspiegelt de voortschrijdende upgrading op de arbeidsmarkı. Technologische veranderingen in de landbouwsector, zoals mechanisering en automatisering, tezamen met schaalvergroting en een groei van het middenkader, leiden tot een stijging van het (vereiste) opleidingsniveau. De verwachte problemen in de personeelsvoorziening in de agrarische sector in Noord- en Midden-Limburg concentreren zich dus naar verwachting op arbeidskrachten met een middelbare opleiding.

De opleidingssectoren die zijn oververtegenwoordigd in Zuid-Limburg zijn met name te vinden in de administratieve sectoren en onder de hoger opgeleiden. Meer specifiek gaat het hier om de vraag naar mensen met een opleiding VMBO Economie, MBO Economie, HBO Economie, HBO Sociaal-cultureel, WO Techniek, WO Medisch, WO Economie en WO Sociaalcultureel. Voor VMBO Economic worden er geen knelpunten in de personeelsvoorziening 
verwacht. Voor de genoemde opleidingen op HBO- en WO-niveau worden er echter wel grote knelpunten in de personeelsvoorziening verwacht. Deze rekruteringsproblemen zullen zich derhalve concentreren in de regio Zuid-Limburg. Ook hier zijn deze moeilijkheden bij het vinden van geëigend personeel voornamelijk het gevolg van de doorzettende upgrading van de vereiste kwalificatie-eisen in veel bedrijfssectoren. Gezien de grotere geografische mobiliteit van de hoger opgeleiden is het echter minder zinvol van regionale krapte te spreken.

\section{Belangrijkste structuurkenmerken per rayon:}

\section{Noord-Limburg}

- Bevolking: 270.820 , dit is $23,8 \%$ van de totale Limburgse bevolking, trend licht stijgend

- Bevolking: gemiddeld iets jonger dan provinciaal gezien

- Relatief laag percentage arbeidsongeschikten (8,3\%), trend licht stijgend

- Aantal niet-werkende werkzoekenden 8.018 , dit is 18,6\% van het totale aantal NWW in Limburg

- Percentage vrouwen NWW bedraagt 51\% (Limburg totaal 50\%), percentage langdurig werklozen bedraagt 56\% (Limburg totaal 59\%). Opvallend zijn het hoge percentage vrouwen in Helden ( $56 \%$ ) en de lage percentages langdurig werklozen in Horst (44\%), Helden (47\%) en Venray (49\%)

- Grootste werkgelegenheidssectoren zijn: gezondheids- en welzijnszorg (Venray 14\%, Venlo $11 \%$ ), detailhandel en reparatie (Venray $8 \%$, Venlo $11 \%$ ) en overige zakelijke dienstverlening (Venlo 7\%)

- Grootste knelpunten op middellange termijn (alleen lager en middelbaar niveau): VMBO (uiterlijke) verzorging, $M B O$ levensmiddelentechniek/vleesverwerking, $M B O$ verpleging, $M B O$ gezondheidstechniek, $M B O$ verzorging, $M B O$ uiterlijke verzorging, $M B O$ horeca, $M B O$ handel en $M B O$ secretariaat.

\section{Midden-Limburg}

- Bevolking: 217.623, dit is 19,1\% van de totale Limburgse bevolking, trend licht stijgend

- Bevolking: gemiddeld iets jonger dan provinciaal gezien

- Relatief laag percentage arbeidsongeschikten $(8,6 \%)$, trend licht stijgend

- Aantal niet-werkende werkzoekenden 7.769 , dit is $18,1 \%$ van het totale aantal NWW in Limburg

- Percentage vrouwen NWW bedraagı $52 \%$, percentage langdurig werklozen bedraagt $60 \%$

- Grootste werkgelegenheidssectoren zijn: gezondheids- en welzijnszorg (Roermond $14 \%$ ), detailhandel en reparatie (Roermond 9\%, Weert 10\%), overige zakelijke dienstverlening (Roermond 10\%, Weert 8\%) en bouwnijverheid (Weert 8\%)

- Grootste knelpunten op middellange termijn: VMBO (uiterlijke) verzorging, MBO levensmiddelentechniek/vleesverwerking, MBO verpleging, MBO gezondheidstechniek, MBO verzorging, $M B O$ uiterlijke verzorging, $M B O$ horeca, $M B O$ handel en $M B O$ secretariaat. 


\section{Westelijke Mijnstreek}

- Bevolking: 168.738 , dit is $14,8 \%$ van de totale Limburgse bevolking, trend licht dalend

- Bevolkingsopbouw op het provinciale gemiddelde

- Relatief hoog percentage arbeidsongeschikten (11,1\%), trend stijgend

- Aantal niet-werkende werkzoekenden 5.676, dit is 13,2\% van het totale aantal NWW in Limburg

- Percentage vrouwen NWW bedraagt 50\%, percentage langdurig werklozen bedraagt $55 \%$. Opvallend zijn de lage percentages langdurig werklozen in Geleen (49\%) en Beek $(49 \%)$

- Grootste werkgelegenheidssectoren zijn: gezondheids- en welzijnszorg (11\%), vervaardiging van chemische producten (10\%), detailhandel en reparatie $(10 \%)$ en vervaardiging van auto's etc. (10\%)

- Grootste knelpunten op middellange termijn: VMBO (uiterlijke) verzorging, MBO procestechniek, $M B O$ levensmiddelentechniek/vleesverwerking, $M B O$ verpleging, $M B O$ gezondheidstechniek, $M B O$ verzorging, $M B O$ uiterlijke verzorging, $M B O$ horeca, $M B O$ handel en MBO secretariaat.

\section{Parkstad Limburg}

- Bevolking: 269.829, dit is 23,7\% van de totale Limburgse bevolking, trend licht dalend

- Bevolking: gemiddeld iets ouder dan provinciaal gezien

- Relatief hoog percentage arbeidsongeschikten (12,1\%), trend stijgend

- Aantal niet-werkende werkzoekenden 12.587, dit is 29,3\% van het totale aantal NWW in Limburg

- Percentage vrouwen NWW bedraagt 47\%, percentage langdurig werklozen bedraagt $59 \%$. Opvallend is het hoge percentage langdurig werklozen in Kerkrade $(68 \%)$

- Grootste werkgelegenheidssectoren zijn: gezondheids- en welzijnszorg (15\%) en detailhandel en reparatie ( $12 \%$ )

- Grootste knelpunten op middellange termijn: VMBO (uiterlijke) verzorging, MBO levensmiddelentechniek/vleesverwerking, $M B O$ verpleging, $M B O$ gezondheidstechniek, MBO verzorging, $M B O$ uiterlijke verzorging, $M B O$ horeca, $M B O$ handel en $M B O$ secretariaat.

\section{Maastricht-Mergelland}

- Bevolking: 210.925 , dit is 18,5\% van de totale Limburgse bevolking, trend licht stijgend

- Bevolking: gemiddeld iets ouder dan provinciaal gezien

- Percentage arbeidsongeschikten op het provinciale gemiddelde (9,9\%), trend stijgend

- Aantal niet-werkende werkzoekenden 8.945 , dit is $20,8 \%$ van het totale aantal NWW in Limburg

- Percentage vrouwen NWW bedraagt 49\%, percentage langdurig werklozen bedraagt $60 \%$. Opvallend is het lage percentage langdurig werklozen in Valkenburg (50\%)

- Grootste werkgelegenheidssectoren zijn: gezondheids- en welzijnszorg (14\%), overige zakelijke dienstverlening (13\%) en detailhandel en reparatie (10\%)

- Grootste knelpunten op middellange termijn: VMBO (uiterlijke) verzorging, MBO levensmiddelentechniek/vleesverwerking, MBO verpleging, $M B O$ gezondheidstechniek, MBO verzorging, $M B O$ uiterlijke verzorging, $M B O$ horeca, $M B O$ handel en $M B O$ secretariaat. 


\subsection{Sectorspecifieke knelpunten: oorzaken en oplossingen}

De aansluitingsproblematiek in de sector horeca, toerisme en recreatie ${ }^{28 .}$.

De sector horeca, toerisme en recreatie wordt onderverdeeld in een aantal bedrijfsgroepen, te weten ${ }^{29}$ :

- Drankverstrekkende bedrijven

- Spijsverstrekkende bedrijven

- Maaltijdverstrekkende bedrijven

- Logiesverstrekkende bedrijven

- Dagrecreatie

- Verblijfsrecreatie

- Reis- en informatiebemiddeling

- Vervoer-en touroperators.

De sector bestaat voornamelijk uit kleinere bedrijven waar minder dan 20 personen werken. In Limburg behoort ongeveer $90 \%$ van de bedrijven in de sector tot de categorie kleinere bedrijven.

De positieve effecten van de economische groei op de sector horeca, toerisme en recreatie zijn in Limburg wat minder aanwezig dan in de rest van Nederland. Mogelijk beperkı de krapte op de arbeidsmarkt de groeimogelijkheden. De sector zal ervoor moeten waken dat de kwaliteit van het aanbod van vakbekwaam en correct personeel hoog blijft.

De groei van het aantal bedrijven in de horeca blijft in Limburg wat achter bij de groei op nationaal niveau. Er is in de meeste subsectoren zelfs sprake van een lichte daling. Dit geldt met name voor de drankverstrekkende bedrijven, de maaltijdverstrekkende bedrijven en de logiesverstrekkende bedrijven. Alleen de spijsverstrekkende bedrijven groeien in aantal, met ruim 5\%. Daarmee groeit het aantal spijsverstrekkende bedrijven in Limburg bijna driemaal zo snel als in Nederland als geheel.

De knelpunten op de Limburgse arbeidsmarkt worden voor de horeca als gemiddeld getypeerd. In vergelijking met de grote krapte in 1998 is de situatie vanuit werkgeversoptiek verbeterd. Het percentage langdurig openstaande vacatures is het afgelopen jaar met $6 \%$ punt gedaald tot $32 \%$. Het percentage langdurig openstaande vacatures is daarmee nog altijd aanzienlijk. Er bestaan binnen Limburg enkele regionale verschillen. De regio's met veel seizoenwerk (Heuvelland), plaatsen die met het openbaar vervoer slecht bereikbaar zijn in de avonduren (vakantieparken in Noord- en Midden-Limburg) of gebieden waar minder studenten woonachtig zijn, hebben de meeste moeite met de werving van personeel.

28 Deze subparagraal is een samenvatting van de Sectorrapportage horeca, toerisme E recreatic van her ETIL.

29 De eerste vier bedrijfsgroepen vallen onder de subsector horeca, de overige vier onder de subsector toerisme en recreatie. 
De problemen die in de sector horeca, toerisme en recreatie spelen hebben ook een kwalitatieve achtergrond. De kwaliteit van de producten en diensten die geleverd worden is steeds meer afhankelijk van de persoon die ze levert. De houding, de flexibiliteit en de sociale vaardigheden van het personeel worden in de sector steeds belangrijker. De eisen die aan goed personeel worden gesteld veranderen hierdoor en worden steeds algemener, waardoor de sector feller met andere sectoren moet concurreren. De lastige arbeidsomstandigheden ((onregelmatige) werktijden, lichamelijk zwaar werk), de beperkte loopbaanmogelijkheden en het ongunstige imago van de sector maken het moeilijker om aan goede mensen te komen.

Bovendien bestaat de personeelsstructuur van waaruit de bedrijven in de horecasector werken uit een kleine harde kern van vakkrachten met een voltijds contract voor onbepaalde tijd, met daaromheen een grote groep oproep-, hulp-, uitzend- en seizoenkrachten. Deze laatste flexibele 'schil' bestaat voor het merendeel uit jonge mensen zonder horecaopleiding met tijdelijke, variabele contracten. Ook dit aspect maakt de sector horeca, toerisme en recreatie op een krappe arbeidsmarkt extra kwetsbaar bij de werving en het behoud van personeel.

Het werk in de horeca-sector eist erg veel van de mensen, niet alleen wat betreft vakkennis, maar ook wat betreft mensenkennis, multi-inzetbaarheid en sociaal-normatieve vaardigheden. Dit alles maakt de werving van geschikt personeel vaak lastig.

Het bovenstaande geeft een redelijke verklaring voor het feit dat bedrijven binnen de Limburgse horeca, toerisme en recreatie-sector veelvuldig geconfronteerd worden met langdurig openstaande vacatures. Van de bedrijven in de sector heeft 33 tot $45 \%$ structureel problemen met het vinden van goede krachten. Bij de seizoenbedrijven heeft zelfs de helft van de bedrijven hiermee te kampen. In het algemeen zijn vacatures voor seizoenkrachten, oproepkrachten en weekendhulpen moeilijk vervulbaar.

Binnen de horeca zijn de problemen het grootst in de keuken (afwashulpen, keukenassistent, kok), maar ook in de bediening is sprake van grote knelpunten in de personeelsvoorziening (medewerkers bediening, gastheren en -vrouwen, leidinggevenden). Van de langdurig openstaande vacatures in de horeca heeft $49 \%$ betrekking op de bediening. Ten slotte blijkt het moeilijk om voldoende barkeepers, medewerkers cafetaria/fastfood, kamermeisjes en kantinepersoneel voor de avonduren te vinden.

Voor de subsector toerisme en recreatie zijn de wervingsproblemen het grootst waar het gaat om koks en medewerkers bediening. Daarnaast is het moeilijk aan interieurverzorgers, beveiligingsmedewerkers, receptionisten, leidinggevenden en controllers te komen. Ook is er in enkele meer specifieke beroepen sprake van knelpunten in de personeelsvoorziening: touringcarchauffeurs, medewerkers dagrecreatie, reisadviseurs en sportinstructeurs.

Verklaringen voor het bestaan van het grote aantal langdurig openstaande vacatures kunnen worden gezocht aan zowel de aanbodzijde als de vraagzijde van de arbeidsmarkt. 
Aanbod gerelateerde factoren zijn:

- Ontgroening

- Afname van het aanbod van leerlingen in de beroepsbegeleidende leerweg

- Een afnemende interesse voor functies in de horeca

- Afname aanbod door concurrentie vanuit andere sectoren (tuinbouw en zakelijke dienstverlening) of verwante bedrijfstypen (bedrijfscatering, zorginstellingen en detailhandel)

- Afname aanbod door arbeidsvraag vanuit het buitenland, vooral voor schoolverlaters van de middelbare en de hogere hotelschool

- In Noord-Limburg wonen erg weinig studenten

- Euregionale verschillen in de sociaal-fiscale wetgeving maken pendel lastig.

Vraag gerelateerde factoren zijn:

- Groei van de werkgelegenheid

- Arbeidsvoorwaarden zijn relatief onaantrekkelijk

- Arbeidsomstandigheden zijn ongunstig

- Seizoenwerk biedt weinig zekerheid

- Grote voorkeur voor jongeren

- Personeelsbeleid krijgt onvoldoende prioriteit

- Werklokatie is vaak slecht bereikbaar

- Imago horeca.

De oorzaken van het grote aantal langdurig openstaande vacatures verschillen overigens per beroep. Voor koks is bijvoorbeeld het aanbod te gering, terwijl voor kelners de leefijdsgrens te laag wordt gelegd, zodat de wat oudere, meer ervaren gastheren en -vrouwen moeilijk aan een baan kunnen komen. Bovendien hebben goede koks weinig interesse in een baan bij een wegrestaurant. Voor reisadviseurs is de afstand tussen de opleiding en de praktijk nog erg groot, terwijl voor touringcarchauffeurs de toenemende werkdruk de belangstelling voor deze functies afremt.

Voor de korte termijn blijven de knelpunten naar alle waarschijnlijkheid bestaan zoals ze nu zijn, waarbij de meeste knelpunten worden verwacht voor de intericurverzorgers. chauffeurs, receptionisten, café- en snackbarhouders, sportinstructeurs, verzorgend personeel en bedrijfshoofden horeca. Op de middellange termijn worden echter nog slechts knelpunten verwacht voor de bedrijfshoofden, sportinstructeurs, café- en snackbarhouders en receptionisten. Voor de overige beroepsgroepen worden voor 2004 geen knelpunten verwacht. Problemen zullen vooral ontstaan bij de receptionisten, die naar verwachting in 2004 te maken krijgen met zeer grote knelpunten. Interviews in het veld maken cluidelijk dat men binnen de sector verwacht dat de arbeidsmarktsituatie in de toekomst zal verslechteren. 
De gewenste inspanningen kunnen in een viertal categorieèn worden ingedeeld, te weten:

\section{Aansluiting onderwijs-arbeidsmarkt}

2. Alternatieve wervingsmethoden, -kanalen en -categorieēn

3. Arbeidsvoorwaarden, werkomstandigheden en personeelsbeleid

4. Bedrijfsoverstijgende maatregelen.

\section{Ad 1. Aansluiting}

Bij de beschrijving van de knelpunten op de arbeidsmarkt is naar voren gekomen dat er weliswaar knelpunten bestaan, maar dat het daarbij vooral gaat om gebrekkige kwalitatieve aansluiting. Dit geldt dan in het bijzonder voor werknemers die tot de vaste kern van het personeel behoren. Voor hen zijn horecagerichte opleidingskwalificaties en bedrijfstakervaring veelal een vereiste. Verder worden deze mensen geconfronteerd met een aantal technologische veranderingen (vooral in de ICT-sfeer) en snel veranderende trends. Onderwijs en scholing zijn de aangewezen middelen om de beperkte aansluiting te verbeteren. Hiertoe is het volgende mogelijk:

- Opzetten van opleidingstrajecten voor combinatiefuncties

- Allround opleidingen voor horeca- en recreatiemedewerkers

- Meer op de praktijk gericht scholen

- Voorlichting aan schoolverlaters gericht op realistische verwachtingen ten aanzien van toekomstige functie

- Voorlichting gericht op bedrijfsleven, omtrent opleidingen en stageplaatsen.

\section{Ad 2. Werving}

Het aanboren van alternatieve wervingscategorieèn kan voor de Limburgse bedrijven in de sector horeca, toerisme en recreatie een belangrijke oplossing zijn bij het opvullen van langdurig openstaande vacatures. De categorieèn niet-werkenden die het meest in aanmerking komen zijn:

- Niet-werkende werkzoekenden (voor bediening, keuken en schoonmaak)

- Herintreders (bediening, schoonmaak en touringcarchauffeurs)

- Allochtonen, asielzoekers en migranten (keuken, bediening en schoonmaak)

- 40+-ers

- Gedeeltelijk arbeidsgeschikten (technische ondersteuning).

Naast deze groepen is er ook de mogelijkheid om over de grens te gaan werven in Duitsland, België, Portugal en Polen. Ook hierbij moet vooral worden uitgekeken naar keuken-, schoonmaak- en bedienend personeel. Problemen doen zich bij internationale werving met name voor op het gebied van taal, cultuur en mentaliteitsverschillen. Bovendien vraagt clke wervingscategorie om een eigen benadering. 


\section{Ad 3/4. Arbeidsvoorwaarden, werkomstandigheden en personeelsbeleid}

Extra investeringen in de professionalisering van het personeelsbeleid zijn nodig om werk en imago structureel te verbeteren en daarmee de aantrekkingskracht van de sector te vergroten. Op sectorniveau verdient vooral het imago van de horecasector de aandacht. Dit imago kan worden verbeterd door allereerst zorg te dragen voor een striktere naleving van de horeca-CAO. Behalve het verbeteren van het imago is de onderlinge samenwerking tussen bedrijven binnen de sector nog zeer beperkt. Ten slotte verdient de discussie omtrent flexibiliteit en zekerheid nog extra aandacht, zo blijkt uit gesprekken met werkenden binnen de sector.

\section{De aansluitingsproblematiek in de sector overheid en onderwijs ${ }^{30}$}

De sector overheid en onderwijs is ten behoeve van deze rapportage eveneens onderverdeeld in een drietal subsectoren, te weten:

- Overheid in enge zin

- Onderwijs

- Welzijn.

Deze subsectoren bestaan elk afzonderlijk weer uit een aantal bedrijfsgroepen. De subsector overheid in enge zin omvat het openbaar bestuur, politie en brandweer, defensie en justitiële diensten en de rechtskundige dienstverlening. De subsector onderwijs omvat alle vormen van publiek onderwijs, van primair tot hoger. De welzijnssector ten slotte omvat kinderopvang, maatschappelijke dienstverlening, jeugd-en jongerenwerk en overige welzijnszorg.

In de sector overheid en onderwijs werkten in Limburg in mei 1999 ruim 61.000 personen. Hiervan werkte ongeveer $45 \%$ in het onderwijs, $45 \%$ in de overheid in enge zin en $10 \%$ in de welzijnssector. De sector overheid heeft een aandeel van ongeveer $12 \%$ in de totale werkgelegenheid van Limburg. De groei van de werkgelegenheid bij de overheid en onderwijs blijft de laatste jaren iets achter bij de totale werkgelegenheidsgroei. Opvallend is wel dat de werkgelegenheid binnen de welzijnssector in Limburg erg snel groeit. In de periode 1997-1998 met 15\% en in de periode 1998-1999 met 5\%.

Binnen de overheid in enge zin zijn bij het algemeen overheidsbestuur in Limburg bijna 15.000 arbeidsplaatsen. Naar verwachting zal dit aantal arbeidsplaatsen de komende jaren weinig veranderen. Bij de politie en brandweer en justitiële diensten en de rechtskundige dienstverlening zal de werkgelegenheid daarentegen de komende jaren wel toenemen.

In Limburg is het leeuwendeel van de werknemers in het onderwijs werkzaam in het primair onderwijs (ruim 33\%), gevolgd door het hoger en algemeen voortgezet onderwijs met elk ruim 20\%. De werkgelegenheid nam in het primaire onderwijs (kleinere klassen),

30 Deze subparagraal is een samenvatting van de Sectorrapportage overheid van het ETIL. In deze sector rapportage wordt deze sector kortweg angeduid als 'overheid' 
het algemeen voortgezet en het hoger onderwijs de laatste jaren gestaag toe. De werkgelegenheid in het wetenschappelijk onderwijs zal naar verwachting in Limburg toenemen als gevolg van het toenemend aantal studenten.

In de welzijnssector wordt relatief veel gebruik gemaakt van werkgelegenheidsmaatregelen, gericht op de inschakeling van werklozen. Bovendien is er een groot aantal vrijwilligers actief. De werkgelegenheid in de welzijnssector is de laatste jaren in Limburg sterk toegenomen. Vooral in de kinderopvang en het jeugd- en jongerenwerk is sprake van een forse groei. In het ouderenwerk en het emancipatie- en integratiewerk is daarentegen de laatste jaren sprake van een krimpende werkgelegenheid. Voor de toekomst wordt een toename van de werkgelegenheid verwacht in de kinderopvang, het algemeen maatschappelijk werk en de jeugdhulpverlening.

Een regionale verbijzondering van de werkgelegenheid in de overheidssector levert het volgende beeld op:

- Noord-Limburg: relatief veel defensie, weinig justitiële diensten en rechtskundige dienstverlening, veel algemeen voortgezet onderwijs en weinig hoger onderwijs

- Midden-Limburg: relatief weinig politie en brandweer, veel defensie, veel lager en middelbaar onderwijs en weinig hoger onderwijs

- Zuid-Limburg: relatief veel hoger onderwijs en relatief weinig defensie.

De meest voorkomende langdurig openstaande vacatures in de subsector overheid hebben betrekking op technici, ICT-medewerkers, secretariaatsmedewerkers en financieel-administratieve medewerkers. De overheid in enge zin heeft met name behoefte aan instroom van jongeren en tijdelijke krachten. Voor het onderwijs spitsen de moeilijk vervulbare vacatures zich met name toe op het primair onderwijs. Ook invalkrachten zijn erg moeilijk te vinden. Binnen de welzijnssector bestaan met name problemen bij de werving van invalkrachten en begeleiders voor allochtone cliënten.

Voor de overheid in enge zin is het bovendien moeilijk verkeersplanologen, accountmanagers, wijkcoördinatoren, politiesurveillanten, agenten en mensen voor de jeugdzorg te vinden. Het onderwijs heeft moeite om aan docenten voortgezet onderwijs te komen. De welzijnssector ondervindt problemen bij het werven van jeugdhulpverleners, groepsleiders en bedrijfsleiders c.q. unitmanagers.

Voor de overheid in enge zin nemen de kwalificatievereisten toe als gevolg van de toenemende complexiteit van het bestuur en de concentratie op beleidsontwikkelende en controlerende taken. Men spreekt in dit verband wel van een upgrading van de kwalificatie-eisen. De inschatting is dat de openstaande vacatures bij de overheid voor $80 \%$ op HBO/WOniveau liggen en voor $20 \%$ op MBO-niveau. Behalve een hogere opleiding worden ook een brede inzetbaarheid en werkervaring vereist. In het onderwijs en de welzijnssector liggen de vereiste kwalificaties vooral op sociaal-normatief en communicatief vlak.

De langdurig openstaande vacatures in de Limburgse overheidssector zijn ontstaan als gevolg van een aantal aanbod gerelateerde en vraag gerelateerde factoren. 
De aanbod gerelateerde factor is:

- Afname aanbod door concurrentie vanuit andere sectoren.

De vraag gerelateerde factoren zijn:

- Vergrijzing van werkenden binnen de sector

- Herbezetting als gevolg van de verkorting van de werkweek tot 36 uur

- Upgrading opleidingseisen

- Toenemende behoefte aan brede inzetbaarheid

- Veel functies zijn erg opleidingsspecifiek, met name in het onderwijs en in de welzijnssector

- Aantrekkende vraag in primair onderwijs en welzijnssector

- Ongunstig imago op het gebied van arbeidsvoorwaarden (onderwijs); loopbaanontwikkeling, status, bureaucratie en onzekerheid

- Ontmoediging instroom nieuwkomers vanuit het vroegere 'last in first out'-principe

- Toenemende werkdruk.

De verwachte knelpunten in de sector overheid en onderwijs zijn de komende jaren zeer groot. Deze komen voornamelijk voort uit een grote vervangingsvraag, die het gevolg is van de vergrijzing binnen de sector. Het percentage langdurig openstaande vacatures voor de sector overheid en onderwijs is in de periode 1998-1999 gestegen met 11\%-punt, van 38 tot $49 \%$. Dat het moeilijk is de vacatures op te vullen is met name te wijten aan krapte op de arbeidsmarkt, waarmee de onderwijssector wordt geconfronteerd. Bovendien is het voor de onderwijssector lastig te concurreren met de secundaire arbeidsvoorwaarden en loopbaanperspectieven die het bedrijfsleven te bieden heeft. Voor docenten zijn er immers doorgaans geringe loopbaanmogelijkheden binnen het onderwijs.

Wanneer naar de verschillende beroepsgroepen wordt gekeken blijkt dat op de middellange termijn de grootste knelpunten binnen de subsector overheid in enge zin worden verwacht bij receptionisten en administratieve employés. Grote knelpunten, zowel voor de korte als de middellange termijn, worden verwacht voor juridisch en fiscaal medewerkers en juridisch en bestuurlijk medewerkers. Vooral de hoge vervangingsvraag zal voor deze beroepsgroep voor knelpunten zorgen. Op korte termijn worden ten slotte zeer grote knelpunten verwacht voor politie-inspecteurs en officieren. Groot zijn de knelpunten op korte termijn voor brandweerlieden en politieagenten, onderofficieren en beveiligingsemployees.

In het onderwijs worden voor nagenoeg alle beroepsgroepen zowel op korte als op middellange termijn knelpunten in de personeelsvoorziening verwacht. Met name voor leraren basisonderwijs zal er sprake zijn van zeer grote knelpunten. De knelpunten op korte termijn komen met name voort uit de hoge tot erg hoge vervangingsvraag. Voor onderwijskundig medewerkers vormt ook de hoge uitbreidingsvraag een belangrijke oorzaak van de knelpunten.

In de welzijnssector zijn het op korte termijn de werknemers in verzorgende beroepen en de sociale raadslieden en hoofden personeelszaken waar grote tot zeer grote knelpunten 
voor gaan ontstaan. Voor de sociale raadslieden en hoofden personeelszaken moet de oorzaak van de knelpunten met name worden gezocht in de hoge uitbreidingsvraag. Op de middellange termijn worden enkel knelpunten verwacht voor de sociale raadslieden en de hoofden personeelszaken.

Er wordt in drie richtingen gezocht naar oplossingen voor de knelpunten:

1. Verbetering aansluiting onderwijs op arbeidsmarkt

2. Alternatieve wervingsmethoden, -kanalen en -categorieën

3. Arbeidsomstandigheden, werkomgeving en personeelsbeleid.

\section{Ad 1. Aansluiting onderwijs en arbeidsmarkt}

Voor de gehele sector geldt dat het contact en de afstemming tussen onderwijs en arbeidsmarkt op een aantal punten verbeterd kan worden. Met name op het gebied van de opleidingsprofielen is een aantal verbeteringen mogelijk. Omdat de overheid in enge zin werft onder mensen met zeer uiteenlopende opleidingsachtergronden is de relatie tussen opleidingen en de subsector beperkt, waardoor het lastig is de juiste doelgroepen aan te spreken. De concurrentieslag met het bedrijfsleven dat veel gerichter kan werven gaat hierdoor vaak verloren. Het aantal stageplaatsen bij de overheid in enge zin is volgens werkgevers in de sector te beperkt. Als oorzaak wordt aangegeven dat het imago van de sector de belangstelling van leerlingen in eerste instantie doet uitgaan naar het bedrijfsleven.

In het onderwijs bestaat juist een zeer directe band met de opleidingen. Niettemin is de concurrentie met het bedrijfsleven het belangrijkste aandachtspunt voor verbetering. Opmerkelijk is in dit verband dat een relatief grote groep werkenden met een lerarenopleiding werkzaam is buiten het onderwijs. De aansluiting tussen onderwijs en arbeidsmarkt in de welzijnssector wordt over het algemeen positief gewaardeerd. In deze subsector leiden stages vaak tot vaste arbeidscontracten. In sommige gevallen draaien projecten zelfs in hun geheel op stagiaires.

Al met al wordt een drietal mogelijke oplossingen aangedragen ter vermindering van de arbeidsmarktknelpunten via intensievere contacten tussen arbeidsmarkt en opleidingsinstituten:

- Betere profilering en nuancering van de overheid als werkgever

- Actievere betrokkenheid van de overheidsinstellingen bij de inhoudelijke kant van opleidingen

Aanpassing van opleidingen aan de vereiste brede inzetbaarheid in de praktijk.

\section{Ad 2. Alternatieve wervingsmethoden, -kanalen en -categorieën}

De overheid is zeer actief als het gaat om werving binnen de eigen organisatie of branche. Hierbij wordt vooralsnog geworven op basis van de opleidingsachtergrond van mensen. Gezien de vergrijzing binnen de overheidssector en de verkrapping van de arbeidsmarkt lijkt het bekijken van alternatieve wervingscategorieën echter de enige optie om voldoende personeel te kunnen aantrekken. De categorieen die worden genoemd zijn: 
- Uitzendkrachten (invalkrachten)

- Wachtgelders (leerkracht)

- Herintreders (administratief, basisonderwijs)

- Gedeeltelijk arbeidsgeschikten (ondersteunende functies).

Bovendien kan over de grens worden geworven, met name in Duitsland (leerkrachten) en België (welzijnswerk). De ervaringen met de genoemde groepen zijn over het algemeen positief, zij het dat het aan opleiding, talenkennis, ervaring en motivatie nog wel eens schort.

\section{Ad 3. Arbeidsvoorwaarden, werkomstandigheden en personeelsbeleid}

Een derde stap is het verbeteren van de arbeidsvoorwaarden en het creëren van een goede werkomgeving om op die manier de concurrentie met het bedrijfsleven aan te kunnen. Bovendien zou men minder strak moeten vasthouden aan vooropgestelde functiekwalificaties en meer aandacht moeten besteden aan de interne opleiding en begeleiding. Tot dusverre komen deze opties nauwelijks van de grond.

Vanuit het personeelsbeleid wordt vooral het bevorderen van de interne mobiliteit als oplossing aangedragen voor de knelpunten in de personeelsvoorziening. Verschillende instrumenten zijn reeds ontwikkeld om de interne mobiliteit op te voeren. Deeltijdbeleid, seniorenbeleid, om-, bij-, en opscholingstrajecten, functieroulatie, interne mobiliteitsbureaus, loopbaanbegeleiding en mobiliteitsplannen. Of en in hoeverre het inrichten van dergelijke beleidsinstrumenten daadwerkelijk effect sorteert moet de nabije toekomst uitwijzen. Verwacht wordt dat deze beleidsinstrumenten enerzijds het huidige personeel binnen houden en anderzijds nieuw personeel aantrekken. Duidelijk is echter ook dat alleen het bevorderen van de intra-sectorale mobiliteit onvoldoende is om de voorziene knelpunten in de personeelsvoorziening te verminderen. Werving buiten de branche en betere profilering bij schoolverlaters en andere doelgroepen (allochtonen, herintreders) is ook noodzakelijk. Een belangrijk aandachtspunt daarbij is het 'stoffige' imago van de overheid als werkgever. 
DE UMEURGSE ARBEIDSMARKT 1999-2004 


\section{Pendel en participatie: Oplossingen voor knelpunten?}

De arbeidsmarkt in de provincie Limburg heeft een duidelijk internationaler karakter dan elders in Nederland. Limburg neemt dan ook $43 \%$ van de totale pendel vanuit België en $50 \%$ van de pendel vanuit Duitsland voor haar rekening. Toch is het aantal pendelaars relatief gering. Slechts $1,7 \%$ van het totale arbeidsaanbod in Limburg heeft betrekking op pendelaars vanuit de grensstreken in Belgiē en Duitsland. De vrij beperkte omvang van de pendel kan voor een belangrijk deel verklaard worden door de belemmeringen in de sfeer van de sociale zekerheid, belastingen e.d. die ondanks de voortschrijdende Europese samenwerking nog altijd bestaan. Veruit de meeste Belgische grenswerkers zijn in de Limburgse industrie werkzaam. Op duidelijke afstand volgen de kwartaire diensten, de horeca, reparatie en zakelijke dienstverlening en de handel. Ook voor werknemers uit Duitsland geldt dat zij voor het merendeel emplooi vinden in de industrie. Gezien de omvang van het huidige aanbod van grensarbeiders is het weinig realistisch te veronderstellen dat de knelpunten op de Limburgse arbeidsmarkt met behulp van arbeidsaanbod vanuit België en Duitsland in de nabije toekomst opgelost zouden kunnen worden. Hiervoor zou een substantiële verhoging noodzakelijk zijn.

Het percentage mensen dat niet participeert op de arbeidsmarkt ligt in Limburg op een iets hoger niveau dan landelijk. Bijna éénderde deel van de bevolking tussen de 15 en de 64 jaar biedt zich niet aan op de arbeidsmarkt. Dit betekent dat er vanuit een macro-optiek duidelijk mogelijkheden bestaan om via een verhoging van de participatiegraad de krapte op de Limburgse arbeidsmarkt te verminderen. Met name door de participatie van vrouwen te stimuleren kan het aanbod op de Limburgse arbeidsmarkt worden vergroot. Ruim 160.000 Limburgse vrouwen nemen momenteel niet deel aan het arbeidsproces. De knelpunten op de Limburgse arbeidsmarkt doen zich vooral voor bij de middelbare en hogere opleidingsniveaus. Dit betekent dat met name het activeren van de arbeidsreserve met een middelbare of hogere opleiding een effectief middel kan zijn om de knelpunten in de personeelsvoorziening het hoofd te bieden. Het gaat hier in totaal om ongeveer 85.000 mensen, waarvan bijna 60.000 vrouwen. Het bevorderen van de arbeidsmarktparticipatie van deze groep zal, naast investeringen in 'opfriscursussen' of bijscholing, vooral om flankerend beleid vragen. Hierbij moet met name gedacht worden aan het vergroten van de mogelijkheden voor kinderopvang en maatregelen in de sfeer van verlofregelingen, flexibele invulling van werktijden en deeliijdarbeid.

\subsection{Inleiding}

Uit voorgaande hoofdstukken is naar voren gekomen dat de Limburgse arbeidsmarkt gekenmerkt wordt door een tekort aan geschikt personeel op een groot aantal arbeidsmarktsegmenten. In dit hoofdstuk worden de verwachte knelpunten in nader perspectief geplaatst. In de paragrafen 6.2 en 6.3 wordt achtereenvolgens een tweetal specifieke oplossingsrichtingen belicht: het bevorderen van de internationale pendel en het vergroten van de arbeidsmarktparticipatie. Het hoofdstuk wordt in paragraaf 6.4 afgesloten met een aantal aandachtspunten voor het participatiebeleid. 


\subsection{Pendel op de Limburgse arbeidsmarkt}

De provincie Limburg neemt vanwege haar geografische ligging binnen Nederland een bijzondere positie in. Het is de enige provincie die aan beide buurlanden grenst. Dit betekent dat de arbeidsmarkt naar verwachting een duidelijk internationaler karakter heeft dan elders in Nederland. Uit CBS-cijfers komt inderdaad naar voren dat Limburg 43\% van de totale pendel vanuit Belgiẻ en 50\% van de pendel vanuit Duitsland voor haar rekening neemt. Toch is het aantal pendelaars relatief gering. Dit wordt geillustreerd in tabel 6.1. Het aantal pendelaars vanuit Belgiẻ naar Limburg bedroeg in 1998 niet meer dan 6.760. Vanuit Duitsland zijn slechts een kleine 1.000 pendelaars in Limburg werkzaam. De pendel vanuit België is voornamelijk op Zuid-Limburg gericht. Vanuit Duitsland gaat een vrijwel even groot aantal grenswerkers naar Noord- en Midden-Limburg als naar Zuid-Limburg. De vrij beperkte omvang van de pendel tussen België, Duitsland en Limburg kan voor een belangrijk deel verklaard worden door de belemmeringen in de sfeer van de sociale zekerheid, de belastingen e.d. die ondanks de voortschrijdende Europese samenwerking nog altijd bestaan.

Tabel 6.1

Grensarbeiders vanuit België en Duitsland naar Limburg, maart 1998

België Duitsland

\begin{tabular}{lccc}
\hline Noord- en Midden-Limburg & mannen & 720 & 300 \\
& vrouwen & 560 & 170 \\
Zuid-Limburg & mannen & 2.940 & 270 \\
& vrouwen & 2.500 & 170 \\
Limburg totaal & mannen & 3.660 & 570 \\
& vrouwen & 3.060 & 340 \\
& totaal & 6.720 & 910 \\
\hline
\end{tabular}

Bron: CBS

In tabel 6.2 wordı de grenspendel vanuit Belgiē en Duitsland verbijzonderd naar bedrijfssector. Het blijkı dat veruit de meeste Belgische grenswerkers in de Limburgse industrie werkzaam zijn. Op duidelijke afstand volgen de kwartaire diensten, de horeca, reparatie en zakelijke dienstverlening en de handel. Ook voor werknemers uit Duitsland geldt dat zij voor het merendeel emplooi vinden in de industrie. In de vierde kolom van de tabel wordı aangegeven welk deel van het totaal aan grenswerkers uit de beide buurlanden in een bepaalde sector werkt. Ruim 40\% van de Belgische en Duitse werknemers in Limburg blijkt in de industrie werkzaam te zijn. Daarnaast is het aanbod vooral geconcentreerd in de kwartaire diensten, de horeca, reparatic en zakelijke dienstverlening en in de handel. De laatste kolom drukt het totale aanbod van grenswerkers per sector uit als percentage van het totaal aantal werkenden in de desbetreffende sector. Hieruit blijkt duidelijk dat het belang van pendel nog steeds relatief klein is. In de kwartaire diensten is het belang van de pendelaars nog het grootst. Bijna $4 \%$ van de werkenden in deze sector in Limburg is grensarbeider. Daarbij gaat het vooral om verpleegkundigen, verzorgenden e.d. uit België. In de industrie is 3,0\% van 
de werkenden in Limburg grenspendelaar. Ook hier zijn het voornamelijk Belgen die in de Limburgse industrie werkzaam zijn.

Tabel 6.2

Verdeling over sectoren van Belgische en Duitse grensarbeiders in Limburg, maart 1998

\begin{tabular}{lrrrrr} 
& België & Duitsland & totaal & $\%$ & $\%$ \\
\cline { 5 - 7 } Bedrijfsector & 60 & & 60 & 0,8 & 0,4 \\
Landbouw en visserij & 2.910 & 260 & 3.170 & 40,9 & 3,0 \\
Industrie (onuitgesplitst) & 210 & 40 & 250 & 3,2 & 0,7 \\
Bouw en onroerend goed & 840 & 190 & 1.030 & 13,2 & 1,6 \\
Handel & 210 & 150 & 360 & 4,7 & 1,4 \\
Transport en communicatie & 110 & 20 & 130 & 1,7 & 0, \\
Bank- en verzekeringswezen & 950 & 180 & 1.130 & 14,5 & 0,9 \\
Horeca, reparatie en zakelijke dienstverlening & 1.100 & 90 & 1.190 & 15,3 & 3,7 \\
Kwartaire diensten & 140 & 30 & 170 & 2,2 & 0,5 \\
Overheid en onderwijs & 230 & 50 & 280 & 3,5 & 2,8 \\
Overig & & & & & 1,7 \\
& 6.760 & 980 & 7.740 & 100 & 1,7
\end{tabular}

Bron: $C B S / R O A$

Geconstateerd kan worden dat de grenspendel momenteel reeds voor een deel de problemen op bepaalde segmenten van de Limburgse arbeidsmarkt vermindert. Dit geldı met name voor de sectoren kwartaire diensten en industrie, waar het arbeidsaanbod van pendelaars uit met name België relatief groot is. Het is echter weinig realistisch te veronderstellen dat de huidige en verwachte knelpunten op de Limburgse arbeidsmarkt met behulp van arbeidsaanbod vanuit België en Duitsland opgelost zouden kunnen worden. Uit de CBS Statistick Grensarbeid komt naar voren dat het aantal grensarbeiders sinds het begin van de jaren '90 vrijwel onveranderd is geweest, hoewel de knelpunten in Limburg in deze periode aanzienlijk zijn toegenomen. Een arbeidsmarkıbrede bijdrage kan alleen verwacht worden indien grenspendel de komende jaren een substantiële toename te zien zou geven.

\subsection{Non-participatie in Limburg: Omvang en samenstelling}

De voorafgaande hoofdstukken van dit rapport hebben laten zien dat de Limburgse arbeidsmarkt gekenmerkt word door een tekort aan direct inzetbaar personeel. Gezien de verwachting dat deze knelpunten de komende jaren zullen voortduren, kan de vraag gesteld worden in hoeverre het bevorderen van de participatie van de "niet-actieven" in het arbeidsproces soelaas kan bieden. Vanuit deze optiek zal in deze paragraaf de omvang en samenstelling van het niet-participerende deel van de potentiële beroepsbevolking in Limburg in kaart worden gebracht. Daarbij gaat het om mensen die niet, of minder dan 12 uur per week werkzaam zijn en ook niet actief op zoek zijn naar betaalde arbeid voor minstens 12 uur. De samenstelling van de niet-participerende potentiële beroepsbevolking wordt belicht vanuit drie gezichtspunten: geslacht, leeftijd en opleidingsniveau. Deze drie gezichtspunten 
geven een indicatie van de mogelijkheden om de arbeidsmarktparticipatie te verhogen in het licht van de knelpunten op de Limburgse arbeidsmarkt.

\section{Omvang van de non-participatie in Limburg}

Tabel 6.3 geeft een overzicht van de omvang van de non-participatie in Limburg en Nederland. Uit de tabel blijkt dat de non-participatie in Limburg iets hoger is dan landelijk. In Limburg biedt bijna éénderde deel - dat wil zeggen bijna 220.000 mensen - van de bevolking tussen de 15 en de 64 jaar zich niet aan op de arbeidsmarkt.

\section{Tabel 6.3}

Omvang non-participatie in verhouding tot de potentiële beroepsbevolking (exclusief studenten en scholieren), Nederland en Limburg, gemiddelde 1997-1998

\begin{tabular}{lrrr} 
& $\begin{array}{r}\text { potentiële } \\
\text { beroepsbevolking } \\
\text { aantal }\end{array}$ & $\begin{array}{r}\text { niet- } \\
\text { participerend } \\
\text { aantal }\end{array}$ & $\%$ \\
\hline Nederland & 9.381 .000 & 2.720 .500 & 29 \\
Limburg & 695.500 & 219.500 & 32 \\
\hline
\end{tabular}

Bron: CBS/ROA

\section{Arbeidsmarktparticipatie naar geslacht en leeftijd}

In tabel 6.4 wordt inzicht gegeven in de omvang van de non-participatie, verbijzonderd naar geslacht en leeftijd. Tussen de verschillende groepen blijken er aanzienlijke verschillen in arbeidsmarktparticipatie te bestaan. Uit de tabel blijkt dat relatief weinig jongeren na het verlaten van het onderwijs niet actief zijn op de arbeidsmarkt. Ongeveer 15.000 mensen jonger dan 30 jaar nemen niet deel aan het arbeidsproces en zijn ook niet actief op zoek naar een baan.

Bij de mensen van 50 tot en met 64 jaar is de arbeidsmarktparticipatie daarentegen gering. Bijna $60 \%$ van de mensen in deze leeftijdsgroep biedı zich niet (meer) aan op de arbeidsmarkı. De kans is erg groot dat zij door vervroegde uittreding of arbeidsongeschiktheid de arbeidsmarkt definitief hebben verlaten. In dat geval zal het aanzienlijke inspanningen vergen deze groep te activeren en (opnieuw) klaar te stomen voor de arbeidsmarkt. Wat dit betrelt is het waarschijnlijk eflectiever de arbeidsmarktuitstroom van ouderen de komende jaren al te remmen in plaats van de inspanning te richten op de herintreding van degenen die het arbeidsproces reeds hebben verlaten.

Het is niet verrassend dat de arbeidsmarktparticipatie onder mannen veel hoger is dan onder vrouwen. Slechts 16\% van de Limburgse mannen tussen de 15 en de 64 jaar heeft geen werk en zoekt ook niet actief naar werk. Bij de vrouwen is dit percentage veel hoger, namelijk $+8 \%$. Dit betekent dat ruim 160.000 Limburgse vrouwen niet deelnemen aan het arbeidsproces. 
Geconcludeerd kan worden dat er vanuit een macro-optiek duidelijk mogelijkheden bestaan om via een verhoging van de participatiegraad de krapte op de Limburgse arbeidsmarkt te verminderen. Met name door de participatie van vrouwen te stimuleren kan het aanbod op de Limburgse arbeidsmarkt worden vergroot. Ook de arbeidsmarktparticipatie onder ouderen is relatief laag. Wanneer zij echter door vervroegde uittreding of arbeidsongeschiktheid de arbeidsmarkt reeds definitief hebben verlaten, zal het erg moeilijk zijn deze groep opnieuw aan het werk te krijgen.

Tabel 6.4

Non-participatie naar geslacht en leeftijd, Limburg, gemiddelde 1997-1998

\begin{tabular}{lrrr} 
& $\begin{array}{r}\text { potentiële } \\
\text { beroepsbevolking } \\
\text { aantal }\end{array}$ & $\begin{array}{r}\text { niet- } \\
\text { participerend } \\
\text { aantal }\end{array}$ & $\%$ \\
\hline $\begin{array}{l}\text { mannen } \\
\text { vrouwen }\end{array}$ & 354.500 & 57.000 & 16 \\
jonger dan 30 jaar & 341.000 & 163.500 & 48 \\
$\begin{array}{l}\text { 30-50 jaar } \\
\text { ouder dan } 50 \text { jaar }\end{array}$ & 126.500 & 15.000 & 12 \\
& 367.500 & 86.500 & 24 \\
totaal & 201.500 & 117.000 & 58 \\
& 695.500 & 219.500 & 32
\end{tabular}

Bron: $C B S / R O A$

\section{Arbeidsmarktparticipatie naar opleidingsniveau}

De knelpunten op de Limburgse arbeidsmarkt worden vooral ervaren bij de middelbare en hogere opleidingsniveaus. Dit betekent dat met name het activeren van de nict-participerenden met een middelbare of hogere opleiding een effectief middel kan zijn om de knelpunten in de personeelsvoorziening het hoofd te bieden. De herintrede van lager opgeleiden vereist echter aanzienlijke scholingsinspanningen, omdat zij vaak nict aan de door werkgevers gestelde opleidingseisen kunnen voldoen. In de praktijk betekent dit doorgaans dat zij tot op MBO-niveau moeten worden 'opgeschoold'.

In tabel 6.5 wordt een overzicht gegeven van de arbeidsmarktparticipatie naar opleidingsniveau. De tabel nuanceert het macro-beeld dat uit tabel 6.3 naar voren komt. Uit de tabel blijkı dat de non-participatie bij de middelbaar en hoger opgeleiden op een veel lager niveau ligt dan bij de lager opgeleiden. Uit de tabel valt af te leiden dat bijna $60 \%$ van de "niet-actieven" 31 een lagere opleidingsachtergrond (slechts basisonderwijs of een VMBOopleiding) heeft. Ook een groot deel van de werklozen is lager opgeleid. Gezien het feit dat vooral op middelbaar en hoger niveau knelpunten in de personeelsvoorziening worden ervaren, zal het stimuleren van de arbeidsmarktparticipatie van lager opgeleiden gepaard 
dienen te gaan met een omvangrijk scholingsprogramma. Dit betekent dat het bevorderen van de arbeidsmarktparticipatie van de Limburgse 'arbeidsmarktreserve' aanzienlijke opleidingsinvesteringen zal vergen. Dit neemt overigens niet weg dat er in Limburg nog een aanzienlijke groep mensen is met een middelbare of hogere opleiding, die niet aan het arbeidsproces deelnemen. Deze groep zou zeer aantrekkelijk kunnen zijn voor werkgevers die te kampen hebben met grote knelpunten in de personeelsvoorziening. Het gaat hier in totaal om ongeveer 85.000 mensen.

\section{Tabel 6.5}

Non-participatie naar opleidingsniveau, Limburg, gemiddelde 1997-1998

\begin{tabular}{lrrr} 
Opleidingsniveau & $\begin{array}{r}\text { potentiële } \\
\text { beroepsbevolking } \\
\text { aantal }\end{array}$ & $\begin{array}{r}\text { niet- } \\
\text { participerend } \\
\text { aantal }\end{array}$ & $\%$ \\
\hline Basisonderwijs & 100.500 & 55.500 & 55 \\
VMBO & 182.000 & 73.000 & 40 \\
HAVO/VWO/MBO & 279.000 & 64.000 & 23 \\
HBO & 97.000 & 17.500 & 18 \\
WO & 30.500 & 3.500 & 11 \\
Totaal & & & 32
\end{tabular}

\section{Bron: CBS/ROA}

Zoals reeds eerder werd opgemerkt zal het perspectief voor ouderen om terug te keren in het arbeidsproces in veel gevallen gering zijn. Uit tabel 6.6 blijkt dat het relatief lage kwalificatieniveau van de oudere niet-participerende Limburgers een extra belemmerende factor vormt. Ruim de helft van de oudere beroepsbevolking heeft een lagere opleiding. Ook het merendeel van de niet-participerenden is laaggeschoold. Van de bijna 120.000 mensen in de leeftijd van 50 tot en met 64 jaar die niet werkzaam zijn en ook niet actief op zoek zijn naar een baan, hebben er maar liefst 75.000 slechts basisonderwijs of een opleiding op VMBO-niveau. Het stimuleren van de arbeidsmarktparticipatie van de ouderen zal derhalve aanzienlijke (scholings-)investeringen vragen. Dit roept onvermijdelijk de vraag op in hoeverre deze investeringen opwegen tegen de baten. De periode waarin de investeringen rendement op kunnen leveren zal bij oudere arbeidskrachten immers betrekkelijk kort zijn.

Tabel 6.4 liet zien dat bijna 165.000 Limburgse vrouwen tussen de 15 en de 64 jaar niet participeren op de arbeidsmarkt. Uit tabel 6.7 blijkt dat de non-participatie ook onder hoger opgeleide vrouwen, met name op MBO-niveau, relatief hoog is. Dit betekent dat de arbeidsreserve' van vrouwen met een middelbare of hogere opleiding in Limburg relatief groot is. Bijna 60.000 Limburgse vrouwen hebben een opleiding op $\mathrm{MBO}$-niveau of hoger afgerond en zijn thans niet actief op zoek naar een baan. Het bevorderen van de arbeidsmarktparticipatie zal, naast investeringen in 'opfriscursussen' of bijscholing gericht op herintredende vrouwen, vooral om flankerend beleid vragen. Hierbij moet met name gedachı worden aan het vergroten van de mogelijkheden voor kinderopvang en maatregelen in de sfeer van verlofregelingen, flexibele invulling van werktijden en deeltijdarbeid. 
Tabel 6.6

Non-participtie ouderen (ouder dan 50 jaar) naar opleidingsniveau, Limburg, gemiddelde 1997-1998

Opleidingsniveau

potentiële

niet-

beroepsbevolking

participerend

aantal

aantal

Basisonderwijs

46.500

35.000

75

VMBO

61.500

40.000

HAVO/NWO/MBO

60.000

30.000

$\mathrm{HBO}$

25.500

10.500

41

WO

7.500

1.500

Totaal

Bron: $C B S / R O A$

\subsection{Achtergronden van non-participatie}

Concluderend kan gesteld worden dat er ongeveer 85.000 middelbaar en hoger opgeleide Limburgers niet participeren (zie tabel 6.5). Vanuit een macro-optiek vormen zij een aantrekkelijk potentieel om de tekorten aan direct inzetbaar personeel te verminderen. Deze groep bestaat met name uit vrouwen. Ongeveer 60.000 vrouwen hebben minimaal een opleiding op MBO-niveau afgerond, maar hebben momenteel geen betaald werk. Het bevorderen van de arbeidsmarktparticipatie zal, naast eventuele investeringen in scholing, gericht op herintredende vrouwen, vooral flankerend beleid zoals het bevorderen van de mogelijkheden voor kinderopvang vragen. Er is ook een grote groep ouderen die niet participeren op de Limburgse arbeidsmarkt. Een groot deel van hen is echter slecht gekwalifi-

Tabel 6.7

Non-participatie vrouwen per opleidingsniveau, Limburg, gemiddelde 1997-1998

Opleidingsniveau

potentiële

niet-

beroepsbevolking

aantal

participerend

Basisonderwijs
VMBO

HAVO/NWO/MBO

100.000

(1.000

58.000

aantal

$\mathrm{HBO}$

132.000

46.000

43.500

12.000

WO

8.500

1.500

28

17

Totaal

341.000

163.500 
ceerd. Het stimuleren van de arbeidsmarktparticipatie van de ouderen zal derhalve aanzienlijke (scholings-)investeringen vragen die slechts een beperkt rendement op kunnen leveren.

De mate waarin mensen op de arbeidsmarkt participeren, hangt sterk samen met een aantal individuele kenmerken. Zo is het arbeidsaanbod van mannen structureel hoger dan dat van vrouwen, onafhankelijk van de leeftijd en het opleidingsniveau. Bij de mannen stijgt de participatie tot ongeveer middelbare leeftijd, waarna deze snel daalt. Voor vrouwen met kinderen is de participatie duidelijk lager rond het dertigste levensjaar. Wel blijkt er een groot verschil in participatiekans te bestaan tussen jonge vrouwen zonder kinderen en vrouwen met kinderen ${ }^{32}$. Voor zowel mannen als vrouwen neemt de participatie overigens toe naarmate het opleidingsniveau hoger is.

Daarmee is echter nog niets gezegd over achterliggende oorzaken. Of mensen zich uiteindelijk al dan niet op de arbeidsmarkt aanbieden, is van een aantal factoren afhankelijk: Ten eerste is er een aantal macro-economische arbeidsmarktfactoren zoals het niveau van de werkloosheid en de hoogte van het loon dat mensen kunnen verdienen. Daarnaast spelen institutionele factoren een belangrijke rol. Het gaat daarbij om zaken als het belastingsociale-zekerheids- en pensioenstelsel. Voor de participatie van vrouwen zijn vooral ook de mogelijkheden om werk met de zorg voor kinderen te combineren van groot belang. Daarbij gaat het om faciliteiten in de sfeer van kinderopvang, zorgverlofregelingen, flexibele invulling van werktijden en deeltijdarbeid.

Het is zaak om met het oog op de huidige en de te verwachten knelpunten in de personeelsvoorziening de participatie te bevorderen. Non-participatie brengt verschillende maatschappelijke kosten met zich mee. Ten eerste leidt een lagere arbeidsdeelname tot productieverliezen. Daarnaast lopen degenen die niet participeren een groot risico op het verouderen van hun kennis en vaardigheden, omdat men niet meer bijblijft bij de ontwikkelingen op de werkvloer. Er wordt bij het in kaart brengen van de maatschappelijke kosten van non-participatie doorgaans een onderscheid gemaakt tussen primaire en secundaire maatschappelijke kosten". Primaire kosten worden bepaald door de gederfde potentiële productie als gevolg van het niet participeren. Secundaire kosten hangen samen met toekomstige productieverliezen, die ontstaan door het onderbreken van de loopbaan.

Werkloosheid veroorzaakt de hoogste maatschappelijke kosten. De gemiddelde kosten voor werklozen zijn hoog omdat vooral de eerste jaren dat men niet meer werkt hun 'menselijk kapitaal' snel waarde verliest. Daarnaast zijn er de kosten van de sociale uitkering die men ontvangt. De gemiddelde kosten van degenen die vrijwillig niet op de arbeidsmarkı participeren (met name gehuwde vrouwen) zijn daarentegen veel lager. Bij de totale maatschappelijke kosten komt echter het belangrijkste deel juist voor rekening van de laatste groep. Dit heeft te maken met de grote omvang van deze groep. Met het oog hierop is het vooral van belang de arbeidsmarktparticipatie van vrouwen te vergroten.

32 Zic B.T.J. Hooghiemstra en J.G.F. Merens, Variatic in Participatic, Sociaal en Cultureel Planbureau, Den Haag. 1999.

33 Zie FA.G. den Buter, L. Broersma, B. Compaijen en R.B. Dellink. Meer Werkgelegenheid door Stimulering van Arbcidsparticipatic?. OSA-werkdocument W131, Organisatie voor Strategisch Arbeidsmarktonderzoek, Den Haag. 1995. 


\section{Verklarende woordenlijst}

\section{Arbeidsmarktkrapte}

Het begrip arbeidsmarktkrapte dat in deze rapportage gehanteerd wordt, is gedefinieerd als de verhouding tussen het aantal openstaande vacatures en het aantal niet-werkende werkzoekenden in bemiddelingsfase 1 naar beroepssegment of opleidingssector. Wanneer de indicator voor de arbeidsmarktkrapte kleiner is dan én, is er sprake van een aanbodoverschot op het betreffende arbeidsmarktsegment. Wanneer de indicator voor de arbeidsmarktkrapte groter is dan één, is er sprake van een tekort aan niet-werkende werkzoekenden in het betreffende segment. Dit tekort kan twee oorzaken hebben: wanneer het aanbod getalsmatig tekortschiet is er sprake van een kwantitatief probleem. De knelpuntsindicator (zie hier beneden) zal dan groter zijn dan éen. Wanneer het probleem vooral gelegen is in het feit dat het percentage niet-werkende werkzoekenden in fase 1 laag is, is dit tekort vooral een kwalitatief aansluitingsprobleem dat zich zal manifesteren in een knelpuntsindicator kleiner dan één. Aangezien werkzoekenden niet naar bedrijfssector ingedeeld kunnen worden, kan deze maatstaf niet gebruikt worden om de arbeidsmarktkrapte naar bedrijfssector te berekenen. De arbeidsmarktkrapte naar bedrijfssector is daarom gedefinieerd als het gewogen gemiddelde van de arbeidsmarktkrapte naar beroepsgroep. De wegingsfactor is daarbij gebaseerd op het aandeel van de betreffende beroepsgroep in het totale aantal openstaande vacatures in die bedrijfssector. Hoe hoger de arbeidsmarktkrapte in een bedrijfssector, hoe groter de rekruteringsproblemen.

\section{Baanopeningen}

De totale vraag naar nieuwkomers op de arbeidsmarkt, zoals deze is bepaald door de werkgelegenheidsgroei (positieve uitbreidingsvraag) en de vervangingsvraag.

\section{Bedrijfsklasse}

Alle voorkomende bedrijven zijn ingedeeld in een aantal clusters. De totale werkgelegenheidscijfers zijn in deze rapportage verbijzonderd naar 33 bedrijfsklassen.

\section{Bedrijfssector}

Alle voorkomende bedrijven zijn ingedeeld in een aantal clusters. De in deze rapportage gepresenteerde informatie is - met uitzondering van de totale werkgelegenheid - verbijzonderd naar 13 bedrijfssectoren. Deze komen overeen met de door het CPB gehanteerde bedrijfssectorindeling.

\section{Bemiddelingsfase}

Het begrip bemiddelingsfase dat in deze rapportage wordt gehanteerd, is gebaseerd op de indeling zoals die door Arbeidsvoorziening wordt gehanteerd. Arbeidsvoorziening classificeert hierbij de niet-werkende werkzoekenden naar bemiddelbaarheid; wanneer de kwalificatie fase 1 ' aan een werkzoekende word toegekend, is deze in principe direct bemiddelbaar. Wanneer een werkzoekende in een hogere bemiddelingsfase wordt ingedecld, impliceert dit een grotere afstand tot de arbeidsmarkt. 


\section{Beroepsgroep}

Alle voorkomende beroepen zijn ingedeeld in een aantal clusters. In deze rapportage wordt hoofdzakelijk uitgegaan van 127 beroepsgroepen, gebaseerd op de SBC (3-digit) van het CBS.

\section{Beroepssector}

Alle voorkomende beroepen zijn ingedeeld in een aantal clusters. Zo worden in hoofdstuk 1 ell beroepssectoren onderscheiden.

\section{Beroepssegment}

Alle voorkomende beroepen zijn ingedeeld in een aantal clusters. In deze rapportage wordt hoofdzakelijk uitgegaan van 127 beroepsgroepen. In een aantal gevallen wordt echter een indeling naar 43 beroepssegmenten gehanteerd, gebaseerd op de SBC (2-digit) van het CBS.

\section{Bijscholing}

Er is sprake van bijscholing wanneer een scholingstraject de opleidingsachtergrond van een werkzoekende niet verandert.

\section{Bijscholingspotentieel in verhouding tot de scholingsbehoefte}

Het bijscholingspotentieel (in kwantitatieve zin) wordt gevormd door de niet-werkende werkzoekenden in fase 2 en 3 . Het bijscholingspotentieel in verhouding tot de scholingsbehoefte - het verschil tussen de som van de openstaande vacatures en de verwachte baanopeningen enerzijds en de direct inzetbare werkzoekenden (de schoolverlaters en de nietwerkende werkzoekenden in fase 1) anderzijds - geeft aan in hoeverre werkzoekenden door middel van bijscholing hun arbeidsmarktkansen kunnen vergroten. Hoe groter deze verhouding is, hoe groter de mogelijkheden voor de werkzoekenden zijn. Wanneer de bijscholingsbehoefte gering is, zijn de kansen om via bijscholing de arbeidsmarktkansen te vergroten eveneens gering.

\section{Conjunctuurgevoeligheid}

De conjunctuurgevoeligheid van de werkgelegenheid heeft betrekking op de mate waarin de werkgelegenheid voor mensen met een bepaalde opleidingsachtergrond gevoelig is voor veranderingen van de economische situatie. Deze indicator geeft daarmee de mate van werkzekerheid aan. De conjunctuurgevoeligheid wordt bepaald door de sectorale werkgelegenheidsfluctuaties in het verleden te relateren aan de mate waarin een opleidingstype momenteel in de verschillende bedrijfssectoren is vertegenwoordigd. Hierbij wordt rekening gehouden met het feit dat niet ieder opleidingstype even sterk meefluctueent met de werkgelegenheidsschommelingen van de bedrijfssector.

\section{Deeltijdarbeid}

Deeltijdarbeid betreft personen die hoogstens 32 uur maar minstens 12 uur per week werkzaam zijn.

\section{Werkzaam buiten eigen vakrichting}

Een indicatie van de mate waarin arbeidskrachten werkzaam zijn in een functie die niet goed aansluit bij de gevolge opleidingsrichting. De mate waarin schoolverlaters buiten de eigen vakrichting werkzaam zijn wordt in dit rapport vastgesteld door de schoolverlaters 
zelf te laten aangeven in hoeverre voor de door hen uitgeoefende functie de eigen of een verwante opleidingsrichting vereist is.

\section{Flexibel werk}

Van flexibel werk is sprake bij uitzendkrachten, oproepkrachten, invalkrachten, contracten zonder een vast aantal arbeidsuren en indien geen vast dienstverband is overeengekomen.

\section{Knelpuntsindicator}

Het begrip knelpuntsindicator dat in deze rapportage wordt gehanteerd is gedefinieerd als de verhouding tussen het aantal openstaande vacatures dat niet door niet-werkende werkzoekenden in bemiddelingsfase 1 vervuld kan worden en het aantal niet-werkende werkzoekenden in bemiddelingsfase 2 en 3 . Hoe hoger de knelpuntsindicator, hoe minder nietwerkende werkzoekenden met een grotere afstand tot de arbeidsmarkt er beschikbaar zijn voor de openstaande vacatures die niet door direct bemiddelbare werkzoekenden vervuld kunnen worden. Dit impliceert tevens dat een hoge knelpuntsindicator een werkzoekende in het betreffende segment de mogelijkheid biedt via bijscholing de kansen op een baan te vergroten. Wanneer het aantal niet-werkende werkzoekenden in fase 1 het aantal openstaande vacatures overtreft, is de knelpuntsindicator gelijk aan 0 . Er is dan geen sprake van een tekort aan gekwalificeerd aanbod. Het aantal banen schiet juist tekort om alle direct inzetbare werkzoekenden aan werk te helpen.

\section{Langdurig werkzoekende}

Het begrip langdurig werkzoekende dat in deze rapportage wordt gehanteerd, is gedefinieerd als een werkzoekende die langer dan een jaar ingeschreven is bij Arbeidsvoorziening, Opgemerkt dient te worden dat dit niet noodzakelijkerwijs impliceert dat de betreffende werkzoekende tijdens de periode niet gewerkt heeft.

\section{Langdurig openstaande vacature}

Het begrip langdurig openstaande vacature dat in deze rapportage wordt gehanteerd, is gedefinieerd als een vacature die langer dan drie maanden openstaat.

\section{Omscholing}

Er is sprake van omscholing wanneer het scholingstraject de opleidingsachtergrond van een werkzoekende verandert. Omscholing kan zowel niveauverhogend als richtingveranderend van aard zijn.

\section{Onderbenutting}

Een indicatie van de mate waarin arbeidskrachten werkzaam zijn op een functieniveau dat lager is dan hun opleidingsniveau. De onderbenutting van schoolverlaters wordt in dit rapport vastgesteld door de schoolverlaters zelf te laten aangeven welk opleidingsniveau vereist is voor de door hen uitgeoefende functie

\section{Opleidingssector}

Alle voorkomende opleidingen zijn samengevoegd tot een aantal clusters. In deze rapportage wordt voornamelijk uitgegaan van 113 opleidingstypen. In een aantal gevallen wordt echter een indeling naar 26 opleidingssectoren gehanteerd. 


\section{Potentiële beroepsbevolking}

De potentiêle beroepsbevolking omvat de werkenden, de niet-werkende werkzoekenden en de niet-participerenden. Iedereen die tussen de 15 en de 64 jaar oud is en geen voltijdsopleiding volgt, wordt tot de potentiële beroepsbevolking gerekend. Als men meer dan 12 uur per week werkt, wordt men tot de werkzame beroepsbevolking gerekend. Werkt men niet of minder dan 12 uur, maar wil men wel minstens 12 uur per week betaalde arbeid verrichten, dan behoort men tot de werkloze beroepsbevolking. Werkt men niet of minder dan 12 uur, en is men niet op zoek naar betaalde arbeid voor minstens 12 uur per week, dan behoort men tot de niet-participerende beroepsbevolking.

\section{Secundaire arbeidsmarkt}

Dat deel van de markt waar de arbeidsvoorwaarden verhoudingsgewijs slecht zijn. Zo geldt bijvoorbeeld dat mensen die dezelfde werkzaamheden verrichten op de secundaire arbeidsmarkt slechter beloond worden dan op de primaire arbeidsmarkt.

\section{Toekomstig arbeidsmarktperspectief}

Het toekomstig arbeidsmarktperspectief geeft de verhouding tussen aanbod en vraag in de prognoseperiode voor een opleidingstype weer. Als het arbeidsmarktperspectief slecht is, betekent dit dat er in het (de) komende ja(a)r(en) veel meer aanbod van nieuwkomers is dan er baanopeningen zijn. Hierdoor zal de arbeidsmarktpositie gaan verslechteren. Deze verslechtering kan een hogere werkloosheid betekenen, maar door aanpassingsprocessen op de arbeidsmarkt kan dit ook leiden tot het moeten aanvaarden van banen op een lager niveau, een lagere beloning en meer tijdelijke contracten. Omgekeerd zal een goed perspectief tot een grotere kans op werk, maar ook tot een verbeterde positie op andere punten leiden. Het toekomstig arbeidsmarktperspectief per opleidingstype wordt bepaald door middel van de Indicator Toekomstige Arbeidsmarktsituatie (ITA), die is gedefinieerd als de verhouding tussen enerzijds de verwachte instroom van schoolverlaters en het aantal direct bemiddelbare werkzoekenden en anderzijds de verwachte baanopeningen. Naarmate de waarde van de indicator hoger is, is het perspectief slechter. Analoog geeft de Indicator Toekomstige Arbeidsmarkısituatie naar Beroep (ITAB) het arbeidsmarktperspectief naar beroepsgroep weer. Merk overigens op dat een hogere ITA of ITAB een slechtere (toekomstige) arbeidsmarkısituatie impliceert, terwijl een hogere arbeidsmarktkrapte een indicatie is voor een betere (huidige) arbeidsmarktpositie van een opleidingstype.

\section{Toekomstige knelpunten in de personeelsvoorziening}

Als de tockomstige vraag naar werkenden met een bepaalde opleidingsachtergrond groter is dan het aanbod, kunnen knelpunten in de personeelsvoorziening verwacht worden. Vergelijkbaar met de Indicator Toekomstige Arbeidsmarkisituatie (ITA of ITAB, zie hierboven) geeft de Indicator Toekomstige Knelpunten in de personeelsvoorziening naar Beroep (ITKB) deze vraag-aanbod-spanning aan. Het verschil met de ITAB is dat bij de ITKB de uitstroom van werkenden als gevolg van een krimpende werkgelegenheid is meegerekend in de vraag, omdat verwacht mag worden dat bij knelpunten in de personeelsvoorziening deze (gedwongen) uitstroom kan worden afgeremd of elders werk zou kunnen vinden. Naarmate de waarde van de indicator lager is, zijn de verwachte knelpunten groter. Analoog geeft de Indicator Toekomstige Knelpunten in de Personeelsvoorziening (ITKP) de knelpunten naar opleidingstype weer. 


\section{Toekomstige Knelpunten in de personeelsvoorziening naar Beroep}

Voor het vaststellen van de verwachte knelpunten in de personeelsvoorziening naar beroep gebruiken we de Indicator Toekomstige Knelpunten in de personeelsvoorziening naar Beroep (ITKB). Deze indicator geeft aan in welke mate werkgevers problemen ondervinden bij het aantrekken van geschikt personeel. Naarmate de waarde van de ITKB lager is, zijn er meer knelpunten te verwachten. Wanneer het aanbod kleiner is dan de vraag, dan is de ITKB kleiner dan 1,00. De knelpunten in de personeelsvoorziening worden dan als groot getypeerd. Als de waarde van de indicator zelfs kleiner is dan 0,85 dan wordt gesproken van zeer grote knelpunten. Wanneer de ITKB daarentegen tussen 1,00 en 1,05 ligt, dan wordt gesproken van enige knelpunten. Bij een hogere waarde van de ITKB is sprake van vrijwel geen knelpunten, en mocht de ITKB zelfs groter zijn dan 1,15, dan is er sprake van geen knelpunten in de personeelsvoorziening.

\section{Uitbreidingsvraag}

De vraag naar nieuwe arbeidskrachten die ontstaat door groei van de werkgelegenheid. Als er sprake is van een werkgelegenheidsdaling, is de uitbreidingsvraag negatief.

\section{Uitwijkmogelijkheden}

De mate waarin arbeidskrachten met een bepaalde opleidingsachtergrond terecht kunnen komen in andere beroepsgroepen op een aansluitend of hoger functie-niveau. Deze maatstaf geeft daarmee aan in hoeverre arbeidskrachten afhankelijk zijn van de arbeidsmarktsituatie in een bepaald beroep. De uitwijkmogelijkheden worden bepaald met behulp van cen spreidingsindex. Deze index geeft een indicatie van het aantal beroepsgroepen waarnaar men kan uitwijken.

\section{Vacature}

Het begrip vacature is in deze rapportage gebaseerd op de door het CBS gehanteerde definitie van een 'openstaande vacature', zijnde een arbeidsplaats waarvoor personeel word gezocht dat onmiddellijk of zo spoedig mogelijk geplaatst kan worden.

\section{Vacaturegraad}

Het aantal openstaande vacatures per 1.000 werkenden in een bedrijfs- beroeps- of opleidingssector.

\section{Vervangingsvraag}

De vraag naar nieuwe arbeidskrachten die ontstaat doordat de arbeidsplaatsen van werkenden die met pensioen gaan, arbeidsongeschikı worden of zich (tijdelijk) terugtrekken van de arbeidsmarkı opnieuw moeten worden opgevuld. De vervangingsvraag per beroepsgroep kan bovendien ontstaan door de beroepsmobiliteit. Vertrek van werkenden dat niet leidt tot vraag naar nieuwkomers uit hetzelfde opleidingstype of beroepsgroep wordt niet meegerekend als vervangingsvraag.

\section{Vraagoverschot}

Wanneer er op de korte termijn knelpunten in de personeelsvoorziening verwacht worden, kan bij-en omscholing van niel-werkende werkzoekenden een instrument zijn om op deze knelpunten te anticiperen. Het vraagoverschot is gedefinieerd als het verschil tussen de som van de openstaande vacatures en de verwachte baanopeningen enerzijds en de direci inzet- 
bare werkzoekenden - de schoolverlaters en de niet-werkende werkzoekenden in fase l anderzijds. Naarmate dit verschil groter is, is het vraagoverschot groter. Wanneer er weinig tot geen knelpunten zijn, is het aantal baanopeningen en openstaande vacatures kleiner dan het aantal direct inzetbare werkzoekenden; het vraagoverschot is dan gering.

\section{Werkende}

Zie Potentiēle beroepsbevolking.

\section{Werkzoekende}

Het begrip werkzoekende is in deze rapportage gedefinieerd als de bij Arbeidsvoorziening ingeschreven niet-werkende werkzoekenden, uitgezonderd de categorie 'geen beroep op dienstverlening'.

\section{Zelfstandige}

Het begrip zelfstandig bevat ook personen die werkzaam zijn in het bedrijf of de praktijk van hun partner of ouders en free-lancers e.d. 


\section{De nieuwe kwalificatiestructuur}

In dit rapport wordt een opleidingsclassificatie gehanteerd waarin 113 opleidingstypen worden onderscheiden. Uitgangspunt bij de totstandkoming van deze classificatie zijn de substitutiemogelijkheden die op de arbeidsmarkt zijn waargenomen tussen mensen met verschillende opleidingsachtergronden ${ }^{3+}$. Dit impliceert dat opleidingen zijn geclusterd op basis van de mate van overlap in het beroepsdomein. De naamgeving van de opleidingsclassificatie is aangepast aan de nieuwe kwalificatiestructuur zoals die is vastgelegd in de Wet Educatie en Beroepsonderwijs (WEB) en aan de recente invoering van het Voorbereidend Middelbaar Beroepsonderwijs (VMBO).

Reeds sinds 1 januari 1996 is de WEB van kracht waarin een nieuwe kwalificatiestructuur is vastgelegd. Hieronder wordt een overzicht gegeven van de relatie tussen de oude en de nieuwe kwalificatiestructuur. Belangrijkste kenmerken van de nieuwe structuur zijn de vier onderscheiden niveaus en het feit dat deze niveaus leerweg-neutraal zijn. Dat wil zeggen dat een opleiding voor alle niveaus in principe via twee leerwegen gevolgd kan worden. Allereerst is dat de beroepsopleidende leerweg (BOL) die vergelijkbaar is met het oude MBOdagonderwijs. Daarnaast is dat de beroepsbegeleidende leerweg (BBL), waarbij minimaal $60 \%$ van de studieduur uit praktijkvorming bestaat. Deze leerweg is te vergelijken met het 'werkend leren' in het oude leerlingwezen.

\section{Vergelijking oude en nieuwe kwalificatiestructuur volgens de WEB}

\begin{tabular}{|c|c|c|c|c|}
\hline niveau & $\begin{array}{l}\text { nieuwe opleidings- } \\
\text { aanduiding alle sectoren } \\
\text { behalve agrarisch }\end{array}$ & $\begin{array}{l}\text { opleidingsindeling } \\
\text { in de agrarische sector }\end{array}$ & $\begin{array}{l}\text { oude } \\
\text { opleidingsaanduiding }\end{array}$ & duur \\
\hline 1 & assistentenopleiding & $\begin{array}{l}\text { assisterend } \\
\text { beroepsbeoefenaar }\end{array}$ & - & 0,5-1 jaar \\
\hline 2 & basisberoepsopleiding & $\begin{array}{l}\text { beginnend } \\
\text { beroepsbeoefenaar }\end{array}$ & $\begin{array}{l}\text { MBO-kort } \\
\text { leerlingwezen-primair }\end{array}$ & 2.3 jaar \\
\hline 3 & vakopleiding & $\begin{array}{l}\text { zelfstandig } \\
\text { beroepsbeoefenaar }\end{array}$ & $\begin{array}{l}\text { MBO-tussen } \\
\text { MBO-lang } \\
\text { leerlingwezen-secundair }\end{array}$ & 2-4 jaar \\
\hline 4 & middenkaderopleiding & $\begin{array}{l}\text { kaderfunctionaris } \\
\text { leerlingwezen-tertiair }\end{array}$ & MBO-lang & 3-4 jaar \\
\hline 4 & specialistenopleiding & $\begin{array}{l}\text { gespecialiseerd } \\
\text { beroepsbeoefenaar }\end{array}$ & leerlingwezen-tertiair & 1-2 jaar \\
\hline
\end{tabular}


In dit rapport wordt geen onderscheid gemaakt tussen de gevolgde leerweg. Er wordt dus slechis gesproken van MBO bouw en niet van MBO/BBL bouw en MBO/BOL bouw. Het ROA heeft er daarmee (vooralsnog) voor gekozen de classificatie nauw te laten aansluiten bij de in De arbeidsmarkt naar opleiding en beroep tot 2002 gehanteerde opleidingsindeling. Deze keuze is gemaakt op grond van het feit dat het op dit moment nog niet goed mogelijk is om aan te geven welke de gevolgen zijn van de invoering van de WEB voor de arbeidsmarktpositie van het $\mathrm{MBO}$ en van de verschillende leerwegen.

In augustus 1999 heeft de invoering van het VMBO plaatsgehad. In de naamgeving van de opleidingen is de aanduiding VBO dan ook vervangen door VMBO. De eerste examens volgens deze nieuwe structuur zullen worden afgenomen in het schooljaar 2002/2003. Deze samensmelting van MAVO en VBO is vastgelegd in de Wet op het Voortgezet Onderwijs. Binnen het VMBO wordt eerst een basis gevormd en vervolgens krijgt de opleiding een meer specifiek karakter. Tijdens de basisvorming wordt een breed vakkenpakket gehanteerd dat in principe voor iedereen gelijk is. Na twee jaar wordt een keuze gemaakt uit de vier verschillende leerwegen die worden onderscheiden.

De theoretische leerweg is nog niet gericht op een bepaald beroep en bedoeld voor leerlingen die niet veel moeite hebben met studeren. Via deze leerweg is doorstroming naar vaken middenkaderopleidingen in het $\mathrm{MBO}$, maar ook naar HAVO mogelijk. Het niveau is vergelijkbaar met het hoogste niveau in het MAVO. Het ROA heeft er dan ook voor gekozen de naam MAVO te vervangen door VMBO theorie.

De gemengde leerweg is bedoeld voor leerlingen die niet veel moeite hebben met studeren, maar zich wel al gericht willen voorbereiden op bepaalde beroepen. Deze leerweg bereidt voor op vak- en middenkaderopleidingen in het $\mathrm{MBO}$. Het niveau ligt dicht bij dat van de theoretische leerweg.

De kaderberoepsgerichte leerweg bereidt voor op vak- en middenkaderopleidingen in het $\mathrm{MBO}$ en is bedoeld voor leerlingen die het liefst leren door praktisch bezig te zijn.

De basisberoepsgerichte leerweg bereidt voor op basisberoepsopleidingen op het $\mathrm{MBO}$ en is bedoeld voor meer praktisch ingestelde leerlingen.

Schematisch kan dit alles als volgt worden weergegeven:

Overzicht van doorstroommogelijkheden voor verschillende leerwegen in het VMBO

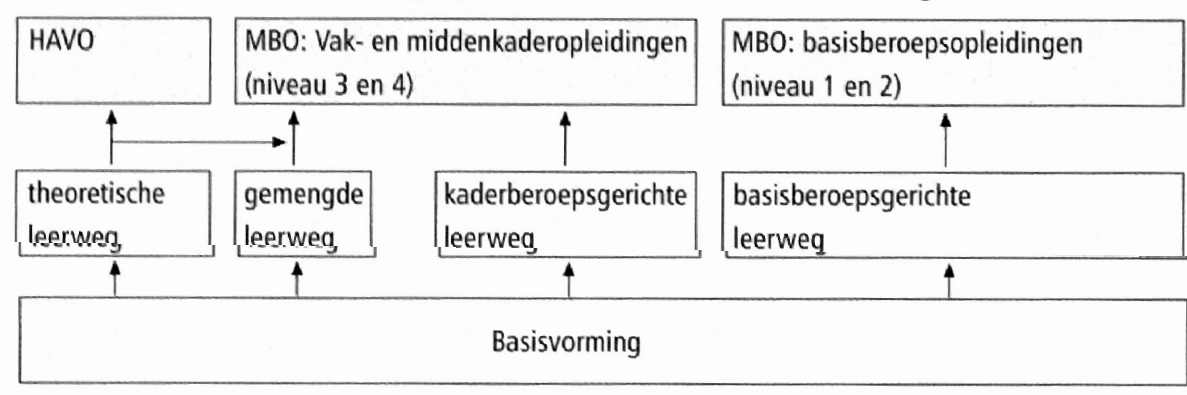

Bron: Ministeric van OConW/ROA 
Tegelijk met het kiezen van een leerweg wordt ook een sector gekozen. Er worden vier sectoren onderscheiden: Zorg en Welzijn, Techniek, Economie en Landbouw. Als een leerling voor een sector kiest, kiest hij of zij voor een vast vakkenpakket dat moet voorbereiden op beroepen binnen die sector. Binnen de kaderberoepsgerichte en de basisberoepsgerichte leerweg volgen leerlingen binnen hun gekozen sector een afdelingsprogramma. De keuze voor een afdelingsprogramma is vergelijkbaar met de keuze voor een opleidingsrichting binnen het VBO. Zo kan een leerling binnen de sector Techniek het afdelingsprogramma Bouwtechniek volgen en daarmee kan hij het diploma voor VMBO Bouwtechniek behalen". Bij de keuze van de opleidingsnamen in de door ROA gehanteerde opleidingsclassificatie is zoveel mogelijk gestreefd naar aansluiting bij de namen van deze afdelingen.

35 Uiteraard kan dat nog via verschillende leerwegen. 